\title{
Carbon Flux in the Temperate Zooxanthellate Sea Anemone Anthopleura aureoradiata
}

\section{Christopher Lynton Gibbons}

\author{
A thesis \\ Submitted to the Victoria University of Wellington \\ in fulfilment of the requirements for the degree \\ Master of Science by Thesis \\ in Marine Biology
}

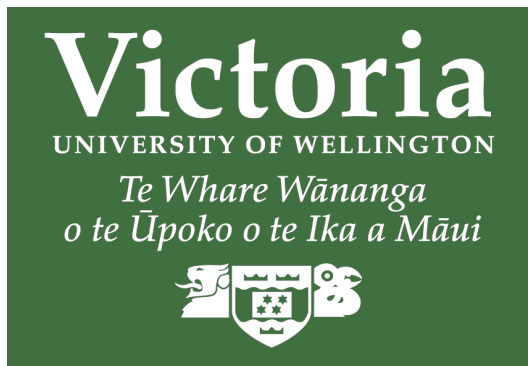

CAPITAL CITY UNIVERSITY

Victoria University of Wellington School of Biological Sciences 2008 


\section{Abstract}

This study investigated the algal density and growth, photophysiology and contribution of algae to animal respiration requirements (CZAR), in the symbiosis between the sea anemone Anthopleura aureoradiata and its dinoflagellate symbionts (zooxanthellae) under field and laboratory conditions. A. aureoradiata was collected during summer and winter on sunny and cloudy days from a rocky shore and mudflat environment. Algal densities displayed a trend of being 2.6 and 1.7 times greater during summer than winter on the mudflat on a sunny and cloudy day respectively. Algal division was asynchronous under field conditions over a daily period, and was 2.1 and 1.3 times greater on the rocky shore and mudflat respectively, during winter than summer on sunny days. Under field conditions, the efficiency and maximum rate of photosynthesis (per cell and per association) as well as respiration rate, were all greater during summer than winter. Cloud cover resulted in a difference in a higher maximum rate of photosynthesis per cell on a sunny day than a cloudy day within summer at Kau Bay. Additionally, these photosynthetic parameters and respiration rate were all greater on the rocky shore than mudflat while the photosynthetic compensation irradiance was greater on the mudflat. The CZAR was greatest on the rocky shore during summer on a sunny day $(151 \%)$ and was also $>100 \%$ on a cloudy day in summer at this same site (129\%); on the mudflat the CZAR was greatest during summer on a sunny day (89\%). The CZAR was measured to be zero during winter at both sites during winter on cloudy days. Additionally, under laboratory conditions A. aureoradiata was exposed to gradual (GTC) and rapid (RTC) temperature changes. While under GTC and RTC, the algal density did not vary, though higher temperatures led to an increase in algal division. Under both GTC and RTC, the photosynthetic efficiency, maximum photosynthetic rate (per cell and per association) and respiration rate all increased with temperature, 
however under GTC these parameters all decreased between $32.5^{\circ} \mathrm{C}$ and $35^{\circ} \mathrm{C}$. Photosynthetic compensation irradiance increased with temperature under both GTC and RTC until $30^{\circ} \mathrm{C}$, after which respiration exceeded maximum photosynthesis, meaning that photosynthetic compensation did not occur. Furthermore, photosynthetic saturation irradiance increased with temperature and peaked at $15^{\circ} \mathrm{C}$ before declining with temperature under both GTC and RTC. The CZAR under GTC increased with temperature until it peaked at $15^{\circ} \mathrm{C}(128 \%)$, before decreasing to zero at $30^{\circ} \mathrm{C}-35^{\circ} \mathrm{C}$. Under RTC, the CZAR was zero for all temperatures except at $10^{\circ} \mathrm{C}$ where it was 25.1\%. A CZAR $<100 \%$ may suggest that the symbiosis between A. aureoradiata and its zooxanthellae is parasitic under most conditions and at most times of the year. Alternatively, there may be some benefit to the symbiosis due to a competitive advantage over other macro-invertebrate species as a result of carbon translocation from the symbiont providing extra support for reproduction and growth. This study also showed A. aureoradiata to have a wide temperature tolerance reflecting the fluctuating conditions of a variable temperate environment. The wide temperature tolerance of this species suggests that it will tolerate short term $(50-100$ years $)$ increases in ocean temperatures however, the threat beyond this time frame with other factors such as ocean acidification remains to be determined. 


\section{Acknowledgments}

First, I would like to thank my supervisor Dr Simon Davy for his patience, tolerance, help and guidance throughout the past 4 years. Additionally, Dr Ken Ryan has also been a big help in giving me advice and helping me solve problems. Thanks to Daniel McNaughtan for all his help with statistical advice, proof reading and the answering of a lot of questions related and unrelated to this degree. Also, Sonja Miller, Shane Geange, Andrew Martin and Joanne Davy were a big help in answering questions and proof reading some of my writing. My lab mates Shyam Morar, Milena Palka and Tiffany Bock for feeding anemones, lab work and also field work; and Sara Mirmoeini for proof reading. My best friend Monira Sos for being somebody who's good to chat to away from science and letting me borrow his car for field work, up until the car accident. Also, thanks to my brother for helping me out with field work and the borrowing of his car to get out to the field. Lastly, my mum for all her support over this period and cooked dinners. 


\section{Contents}

\section{General introduction}

$1.1 \quad$ Symbiosis............................................ 1

1.2 Algal-invertebrate symbiosis and structure $\ldots \ldots \ldots \ldots \ldots \ldots \ldots .2$

1.3 Zooxanthellar diversity and morphology.................... 3

$1.4 \quad$ Onset, recognition and establishment....................... 4

$1.5 \quad$ Nutritional interactions................................... 6

1.5.1 Photosynthesis and photoacclimation................. 6

1.5.2 Carbon translocation................................ 8

1.5.3 Nitrogen metabolism............................. 10

1.6 Temperate vs. tropical symbioses........................... 11

1.6.1 Irradiance........................................ 12

1.6.2 Temperature.................................... 13

$1.7 \quad$ Symbiosis stability.................................... 14

1.7.1 Salinity.......................................... 15

1.7.2 Ultraviolet radiation (UVR) ........................ 15

1.7.3 Temperature....................................... 16

1.7.4 Acclimation vs. adaptation......................... 17

$1.8 \quad$ Anthopleura aureoradiata.................................. 18

$1.9 \quad$ Aims........................................................ 19

2 Carbon flux in the symbiotic intertidal sea anemone Anthopleura aureoradiata

2.1 Introduction ........................................... 20

2.2 Materials and methods.................................. 23

2.2.1 Study species................................... 23 
2.2.2 Field and collection sites

2.2.3 Environmental parameters.......................... 26

2.2.4 Photosynthesis-irradiance relationships................. 26

2.2.5 Protein analysis..................................... 29

2.2.6 Determination of mitotic index (MI) .................. 30

2.2.7 Contribution of zooxanthellae to animal respiration (CZAR)........................................... 31

2.2.8 Statistical analysis.................................. 32

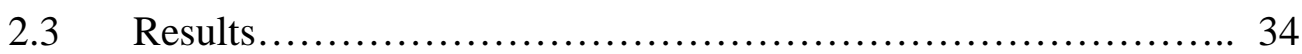

2.3.1 Environmental parameters.......................... 34

2.3.1.1 Irradiance...................................... 34

2.3.1.2 Temperature................................. 34

2.3.2 Algal and symbiosis characteristics.................... 37

2.3.2.1 What is the effect of season on the algal density of $A$. aureoradiata?............................................. 37

2.3.3 Mitotic index........................................ 40

2.3.3.1 What is the affect of season on the MI of algae within A. aureoradiata?..................................... 40

2.3.4 Photosynthesis vs. irradiance......................... 42

2.3.4.1 What is the effect of season and cloud cover on the photophysiology and respiration of $A$. aureoradiata?

2.3.4.2 What is the effect of habitat on the photophysiology and respiration of $A$. aureoradiata?

2.3.5 Rates of respiration, net photosynthesis and carbon translocation and daily CZAR. 46

2.3.6 Daily CZAR 48 
2.4.1 Algal cell size and density $\ldots \ldots \ldots \ldots \ldots \ldots \ldots \ldots \ldots \ldots . \ldots \ldots$

2.4.1.1 Algal cell size.............................. 49

2.4.1.2 Algal densities............................. 50

2.4.2 Algal cell growth............................... 52

2.4.3 Photoacclimation................................. 55

2.4.3.1 How does season and cloud cover affect the photophysiology and respiration of $A$. aureoradiata?................................................... 55

2.4.3.2 How does habitat affect the photophysiology and respiration of $A$. aureoradiata?

2.4.4 Metabolic rate...................................... 58

2.4.4.1 Zooxanthellar biomass...................... 58

2.4.5 CZAR .......................................... 59

2.4.5.1 Carbon translocation........................ 59

2.4.5.2 Daily CZAR................................. 60

2.4.6 Further studies....................................... 63

3 The effect of temperature on carbon flux in the symbiotic intertidal sea anemone Anthopleura aureoradiata

3.1 Introduction............................................ 64

3.2 Materials and methods.................................. 67

3.2.1 Anemone collection and maintenance................. 67

3.2.2 Photosynthesis and respiration measurements............ 67

3.2.3 Determination of mitotic index (MI).................. 69

3.2.4 Contribution of zooxanthellae to animal respiration

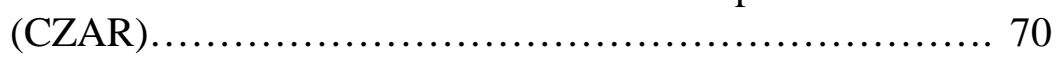

3.2.5 Statistical analysis............................... 71 
3.3.1 Algal and symbiosis biomass characteristics.............. 72

3.3.2 Mitotic index...................................... 75

3.3.3 Photosynthesis - irradiance relationships.............. 76

3.3.4 Carbon and cell specific growth rates and carbon translocation........................................ 83

3.3.5 Daily CZAR ..................................... 85

$3.4 \quad$ Discussion.............................................. 86

3.4.1 Algal density and cell growth..................... 86

3.4.1.1 Algal density............................... 86

3.4.1.2 Mitotic index................................ 88

3.4.2 Photophysiology................................. 89

3.4.2.1 How does the photophysiology of $A$. aureoradiata respond to temperature variations?.. 89

3.4.2.2 What are the possible causes of photoinhibition in A. aureoradiata?............................................. 91

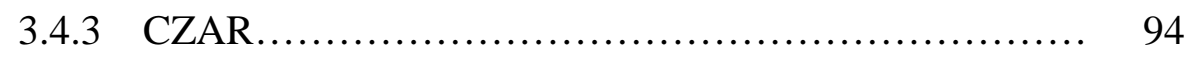

3.4.3.1 Carbon translocation........................ 94

3.4.3.2 Daily CZAR .............................. 95

3.4.3.3 Ecological Implications.................... 96

\section{General Discussion}

4.1 What are the potential benefits of symbiosis to

A. aureoradiata?.................................................................. 97

4.2 Climate change: what is the future for A. aureoradiata?........... 101

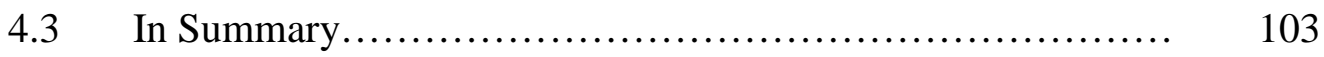




\section{$5 \quad$ Appendices}

5.1 Appendix A

Contribution of zooxanthellae to animal respiration

(CZAR)

5.2 Appendix B

Two sample T-Tests for environmental treatments relating to photosynthetic parameters

5.3 Appendix C

Control temperature algal and symbiosis biomass characteristics, $\mathrm{P}$ - I curve and CZAR measurements and daily mitotic index for gradual and rapid temperature change...

\subsection{Appendix D}

Post-hoc Tukey HSD tables for gradual and rapid temperature Change parameters 


\section{List of figures}

Figure 1.1 Tentacle squash of the sea anemone Anthopleura aureoradiata (Page 3).

Figure 1.2 Anthopleura aureoradiata with tentacles full expanded (Page 19).

Figure 2.1 (A) Anthopleura aureoradiata with tentacles exposed. (B) zooxanthellae residing within $A$. aureoradiata. (C) A dividing zooxanthellae appearing as a double (Page 24).

Figure 2.2 (A) Map of New Zealand, indicating field sites within the Wellington region. (B) Low tide at Pauatahanui Inlet. (C) Anthopleura aureoradiata at the surface of the sediment at low tide. (D) Four individuals of $A$. aureoradiata attached to a cockle shell (Austrovenus stutchburyi) newly excavated from the sediment. (E) Low tide at Kau Bay. (F) Aggregation of A. aureoradiata individuals attached to rocks in the mid-littoral zone (Page 25).

Figure 2.3 $\mathrm{O}_{2}$ flux setup for photosynthesis/irradiance measurements, showing the lap top, water cooler, water heater, glass chamber containing anemones, water bath and the PAR lamp. The PAR lamp was moved progressively closer to the chamber in order to increase irradiance (Page 29).

Figure 2.4 Daily field irradiance. (A) Kau Bay during summer on a sunny and cloudy day. (B) Kau Bay during winter on a sunny and cloudy days (C) Pauatahanui Inlet during summer on a sunny and cloudy day. (D) Pauatahanui Inlet during winter on sunny and cloudy daymeasurements are averages over two days (Page 35).

Figure 2.5 Daily field irradiance. (A) Kau Bay during summer on sunny and cloudy days. (B) Kau Bay during winter on sunny and cloudy days. (C) Pauatahanui Inlet during summer on sunny and cloudy days. (D) Pauatahanui Inlet during winter on sunny and cloudy days (Page 36).

Figure 2.6 Mitotic index for Anthopleura aureoradiata. (A) Kau Bay during summer on a cloudy and sunny day. (B) Kau Bay during winter on a cloudy and sunny day. (C) Pauatahanui Inlet during summer on a cloudy and sunny day. (D) Pauatahanui Inlet during winter on a cloudy and sunny day (Page 41).

Figure 2.7 Percentage of algal cells undergoing mitosis from Anthopluera aureoradiata from Kau Bay and Pauatahanui Inlet during summer and winter on overcast and clear sky days (Page 42) 
Figure 2.8 Photosynthesis vs. irradiance curves for Anthopleura aureoradiata. (A) Kau Bay during summer on sunny and cloudy days. (B) Kau Bay during winter on sunny and cloudy days. (C) Pauatahanui Inlet during summer on sunny and cloudy days. (D) Pauatahanui Inlet during winter on sunny and cloudy days (Page 44).

Figure 2.9 Photosynthesis - irradiance parameters for Anthoplerua aureoradiata at Kau Bay and Pauatahanui Inlet during summer and winter on overcast and clear sky days. $(\boldsymbol{A})$ initial slope of $\mathrm{P}-\mathrm{I}$ curve $(\alpha),(B)$ Dark respiration rate of intact symbiosis, $(\boldsymbol{C})$ Compensation irradiance $\left(\mathrm{I}_{\mathrm{c}}\right),(\boldsymbol{D})$ 95\% saturation irradiance $\left(\mathrm{I}_{\mathrm{k}}\right),(\boldsymbol{E})$ Cell specific $\mathrm{P}_{\max } \operatorname{gross},(\boldsymbol{F})$ Maximum rate of photosynthesis ( $\mathrm{P}_{\max }$ gross) (Page 45).

Figure 2.10 Daily CZAR for Anthopleura aureoradiata from Kau Bay and Pauatahanui Inlet during summer and winter on a cloudy and sunny day (Page 48).

Figure 3.1 Mitotic index for Anthopleura aureoradiata under gradual and rapid temperature change treatments (Page 75).

Figure 3.2 Photosynthesis vs. irradiance curves for Anthoplerua aureoradiata subjected to different temperatures. (A) Gradual temperature change (B) Rapid temperature change (Page 81)

Figure 3.3 Photosynthesis - irradiance parameters for Anthopleura aueroradiata subjected to different temperatures. (A) Initial slope of $\mathrm{P}$ - I curve $(\alpha)$. (B) Dark respiration rate of intact symbiosis $(\boldsymbol{C})$ Compensation irradiance $\left(\mathrm{I}_{\mathrm{c}}\right)(\boldsymbol{D})$ 95\% saturation irradiance $\left(\mathrm{I}_{\mathrm{k}}\right)$. $(\boldsymbol{E})$ Cell specific $\mathrm{P}_{\max }$ gross. $(\boldsymbol{F})$ Maximum rate of photosynthesis ( $\mathrm{P}_{\max }$ gross). (Page 82).

Figure 3.4 Daily CZAR for Anthopleura aureoradiata for gradual and rapid temperature change (Page 85).

Figure 3.5 Three proposed primary impacts of elevated temperature on the photosystems of symbiotic algae in hosts (Page 93). 


\section{List of tables}

Table 2.1 Specified concentrations of bovine serum albumen (BSA) to generate a standard curve (Page 30).

Table 2.2 Definitions of the photosynthetic parameters of $\alpha, I_{c}, I_{k}$, cell specific $\mathrm{P}_{\max }$ gross and $\mathrm{P}_{\max }$ gross (Page 33).

Table 2.3 Averaged daily temperatures for Kau Bay and Pauatahanui Inlet during summer and winter on sunny and cloudy days (Page 36).

Table 2.4 Anthopleura aureoradiata algal and symbiosis biomasscharacteristics for summer (Page 38).

Table 2.5. Anthopleura aureoradiata algal and symbiosis biomasscharacteristics for winter (Page 39).

Table 2.6. $\quad$ Parameters used in the estimation of CZAR for Anthopleura aureoradiata from Kau Bay and Pauatahanui Inlet during summer and winter on sunny and cloudy days (Page 47).

Table 3.1 Algal and symbiosis biomass characteristics for Anthopleura aureoradiata from gradual temperature changes (Page 73).

Table 3.2 Algal and symbiosis biomass characteristics for Anthopleura aureoradiata from rapid temperature changes (Page 74).

Table 3.3 Parameters used in the estimation of CZAR for Anthopleura aureoradiata at different temperature treatments under gradual temperature change (Page 84).

Table 3.4 Parameters used in the estimation of CZAR for Anthopleura aureoradiata at different temperature treatments under rapid temperature change (Page 84). 


\section{Chapter 1:}

\section{General introduction}

\subsection{Symbiosis}

The term symbiosis was established by the botanist Henrich Anton De Bary in 1879, to describe the most intimate living relationship between separate species (Wilkerson 2001). Though there is no single definition, symbiosis is commonly referred to as two species living in close association (Smith and Douglas 1987). Symbioses are common in terrestrial, freshwater and marine ecosystems, and have played a significant part in the evolution of life forms over geological time (Moran 2006). Symbioses are separated into three distinct categories: 1. mutualism, where there are advantages for both partners; 2. commensalism, where one species benefits while the other receives little or no benefit or harm; and 3. parasitism, where one partner benefits at the expense of the other (Smith and Douglas 1987; Douglas 1994; Wilkerson 2001). Symbiotic associations may also be characterized as ectosymbiotic in which the symbiont lives on the surface of the host, or, endosymbiotic where the symbiont lives inside the host (Douglas 1994). Additionally, symbiotic relationships may be categorized as obligate, where the symbiosis is necessary for survival of one organism; or facultative, whereby the association is useful but not vital (Smith and Douglas 1987; Douglas 1994; Moran 2006). 


\subsection{Algal-invertebrate symbiosis and structure}

Intracellular symbiotic dinoflagellates ("zooxanthellae") are located within the animal host's endodermis (Trench 1987; Fig 1.1). Zooxanthellae reside within a number of taxonomic classes that are representatives of the phylum Cnidaria. Members include Anthozoa (anemones, scleractinian corals (hard corals), zoanthids, corallimorphs, blue corals, alcyonacean corals (soft corals, and sea fans), Scyphozoa (e.g. the jellyfish Cassiopea sp.) and Hydrozoa (including milleporine fire corals). Zooxanthellae are also found within the molluscan classes Bivalvia and Gastropoda (tridacnid clams, heart cockles), as well as large miliolid Forminifera, sponges, and a giant heterotrich ciliate (see Trench 1993 for review; Carlos et al. 1999; Lobban et al. 2002). The relationship displayed between Cnidaria and its zooxanthellae is thought to be a mutualistic association (Trench 1979, 1987).

Densities of zooxanthellae have been measured at $0.5 \times 10^{6}-5 \times 10^{6}$ cells $\mathrm{cm}^{-2}$ in corals (Drew 1972; Porter et al. 1984; Hoegh-Guldberg and Smith 1989a, 1989b) with each individual zooxanthella cell enclosed within a host-derived membrane known as the perisymbiotic or perialgal membrane (Miller and Yellowlees 1989). Residence inside the perialgal membrane allows host regulation of inorganic nutrients to the zooxanthellae (Rands et al. 1993). 


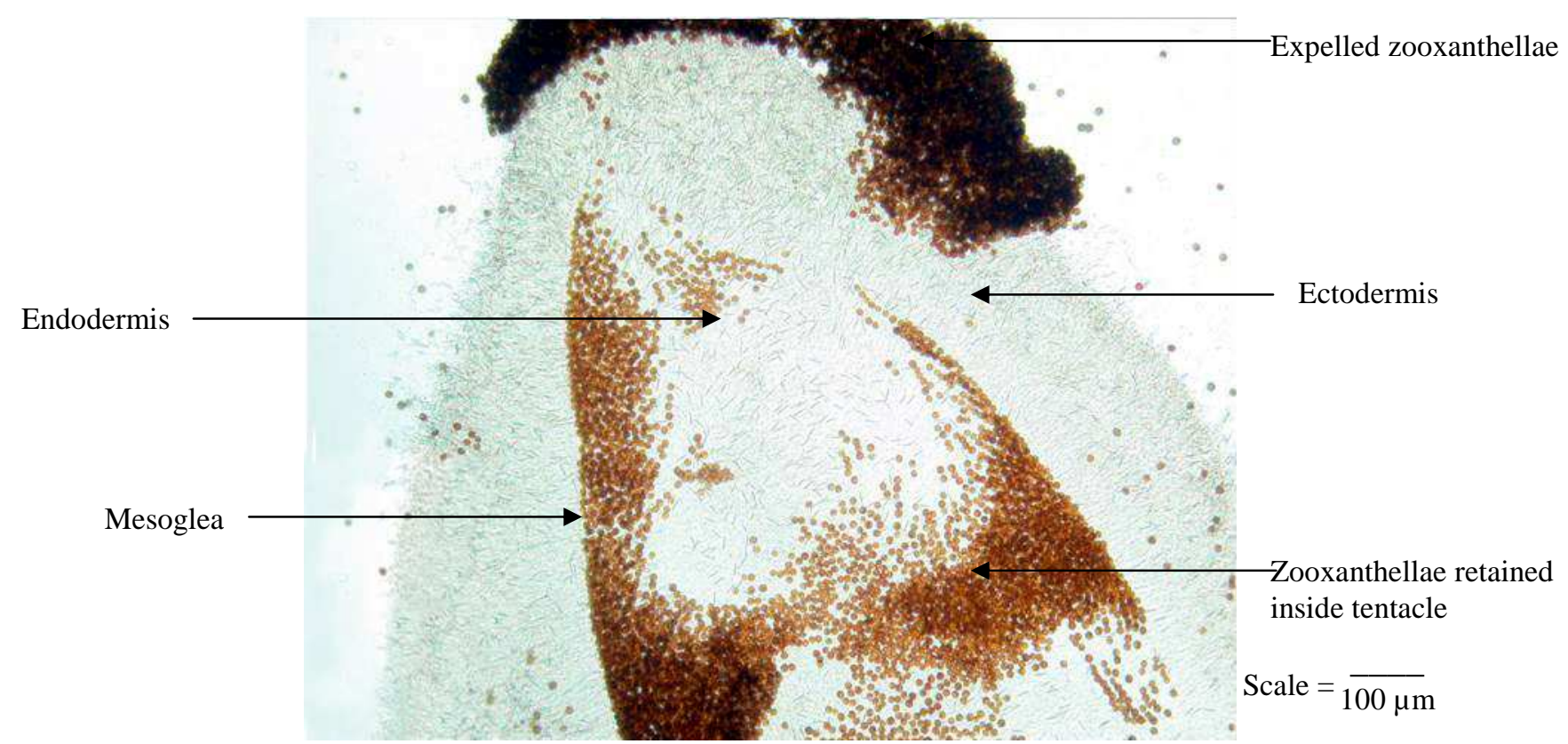

Figure 1.1. Tentacle squash of the sea anemone Anthoplerua aureoradiata showing location of zooxanthellae in the anemones tissues.

\subsection{Zooxanthellar diversity and morphology}

Characteristically, all zooxanthellae have the same dominant phenotype,that of a brown coccoid cell $(5-15 \mu \mathrm{m})$ (Stat et al. 2006). This led early researchers to document zooxanthellae as a single species (Symbiodinium microadriaticum) within marine invertebrate associations (Taylor 1974 cited in Baker 2003). In contrast, molecular genetic studies have revealed a high level of diversity within the genus Symbiodinium (Baker 2003). Molecular genetic studies utilising DNA/DNA hybridization and allozymes (Schoenberg and Trench 1980; Blank and Huss 1989) and using sequences derived from nuclear small subunit ribosomal DNA (18S-rDNA) (Rowan and Powers 1991) determined the genus to be highly heterogeneous and similar to that of orders of free-living dinoflagellates (Rowan and Powers 1992). This led to the development of a classification system for zooxanthellae that divides the genus into several large groups 
or clades, representing divergent lineages, each containing closely related molecular types (Baker 2003). Clades are as follows: A, B, C (Rowan and Powers 1991), D (Carlos et al. 1999), E (LaJeunesse and Trench 2000; LaJeunesse 2001), F (LaJeunesse 2001), G (Pochon et al. 2001), and H (Pochon et al. 2004). Further molecular work has involved using chloroplast (Santos et al. 2002; Takashita et al. 2003) and mitochondrial genes (Takabayashi et al. 2004) as well as the ribosomal transcribed spacer (ITS) region in determining the diversity of zooxanthellae. Using the ITS2 region, LaJeunesse et al. (2003) discovered over 23 and 35 types of zooxanthellae in cnidarians from Australia and the Caribbean, respectively. Furthermore, sampling from numerous hosts on one reef, LaJeunesse et al. (2002) identified 69 types. Currently eleven species have been assigned to the genus Symbiodinium (Baker 2003), but this number is far exceeded by the number of unnamed species likely to exist in this genus.

\subsection{Onset, recognition and establishment}

Zooxanthellae are recruited to the host's endoderm either through maternal inheritance from the parental polyp (vertically) or from zooxanthellae present in the water column (horizontally) (Trench 1987; Douglas 1994). Vertical inheritance of zooxanthellae occurs in the minority $(\sim 15 \%)$ of cnidarian associations (Fadlallah 1983; Babcock and Heyward 1986; Richmond and Hunter 1990) and occurs during the early stages of the host's life history while the offspring are still associated with the parental polyp (Schwarz et al. 2002). Host offspring are guaranteed a founding supply of symbionts, though with limited genetic diversity (Weis et al. 2001), a possible constraint should environmental conditions change (Buddemeier and Fautin 1993). Alternatively, horizontal infection is the mechanism by which the majority $(\sim 85 \%)$ of cnidarian species gain access to symbionts and occurs after they have left the parental polyp. 
This mode of transmission allows host flexibility in choosing a potential symbiotic partner that may be differentially adapted to conditions in which the host ultimately takes up residence (Buddemeier and Fautin 1993; Weis et al. 2001). The failure to establish an association could result in an aposymbiotic host with reduced growth and fitness (Weis et al 2001). There are three suggested methods for horizontal infection. First, motile, free-living zooxanthellae may mass together and enter the host's mouth, otherwise termed "swarming" (Fitt 1984). They then pass through and enter the gastric cavity and are taken up in the endodermal cells by phagocytosis (Kinzie 1974; Fitt 1984). Second, the host may acquire free-living zooxanthellae that it ingests while feeding heterotrophically (Fitt 1984; Schwarz et al. 1999). It has been shown that zooxanthella cells ingested by live brine shrimp can establish an association with the polyp stage of the scyphozoan Cassiopeia xamachana after the host ingests and digests the brine shrimp (Fitt 1984). Lastly, recognition of a symbiont by the host may occur by the interaction of surface molecules, most likely glycoproteins between the symbionts and host (Meints and Pardy 1980; Lin et al. 2000; Wood-Charlson et al. 2006).

The abundance of cnidarians containing different zooxanthellar clades within the same location suggests host-symbiont specificity, where host and/or symbiont select some partners and exclude others (Douglas 1994). For example, Caribbean gorgonian octocorals have reported zooxanthellae representatives belonging to clades B and C with B being most common (Coffroth et al. 2001; Santos et al. 2001; LaJeunesse et al. 2002) whereas clades B, C and D have been found in 14 hard coral colonies sampled from Heron Island on the Great Barrier Reef (laJeunesse et al. 2003). While many studies document hosts consistently accepting their homologous zooxanthellae and rejecting others, hosts accepting heterologous zooxanthellae display reduced fitness and growth (e.g. Kinzie and Chee 1979; Trench 1987; Rodriguez-Lanetty et al. 2003). 
Specificity has been linked to the local environmental conditions. External environmental conditions may promote certain pairings between partners with combinations potentially changing with depth, irradiance, temperature, latitude, longitude and host ontogeny (Coffroth and Santos 2005).

\subsection{Nutritional interactions}

\subsubsection{Photosynthesis and photoacclimation}

Photosynthetic responses of zooxanthellae differ due to changes in irradiance on a diurnal, weekly, monthly and even yearly basis (Gates and Edmunds 1999). Photoacclimation to long term (weeks, months, annual) changes in the quality and quantity of light occurs in response to changes in photon flux density and spectral distribution (Kirk 1983 cited in Anthony and Fabricius 2000). This may occur through morphological changes in algal cell volume, the number and density of thylakoid membranes, the size of pyrenoids and other storage bodies within plastids and sometimes by changes in the number of plastids per cell (Post et al. 1984; Berner et al. 1989). Physiological changes may occur through photosynthesis (Dubinsky et al. 1986), respiration (Geider et al. 1986), and growth (Post et al. 1984; Falkowski et al. 1985).

At a cellular level, photoacclimation may occur through changes in lipid content and composition and pigmentation (Falkowski and Owens 1980; Perry et al. 1981). Changes in pigmentation as a result of photoacclimation may have two main consequences for light absorption properties. First, cells acclimated to high irradiance levels have a relatively high carotenoid concentration in comparison to chlorophyll $a$. This can result in organisms acclimated to high irradiance levels having lower 
maximum quantum yields for photosynthetic oxygen evolution (Morel and Ahn 1990). Second, when cells acclimate to low irradiance levels, the subsequent increase in pigmentation is associated with a decrease in the optical absorption cross-section normalised to chlorophyll $a$ (Falkowski et al. 1985). An increase in chlorophyll pigmentation occurs by either of two basic photoacclimation strategies (Falkowski and Owens 1980, Perry et al. 1981). The first consists of an alteration in the size but not the number of photosynthetic units (PSU); the second is the converse (Falkowski and Owens 1980; Lesser and Shick 1989; Iglesias-Prieto and Trench 1994, 1997). The size of a PSU is usually defined as the ratio of total chlorophyll to reaction centres (either Photosystem I (PS1) or Photosystem II (PSII)) (Falkowski and Owens 1980, Perry et al. 1981). However, the notion of a PSU size based on the ratio of chlorophyll to reaction centres (RC) is ambiguous. For example, if the ratio of PSI to PSII reaction centres changes, then an organism may appear to alter the size of a PSU as determined by chlorophyll/PS - RC I ratios but simultaneously alter the number of PSUs as determined by chlorophyll/PS - RC II ratios (Falkowski et al. 1981). This effect is due primarily to the self-shading of the chromophores between layers of thylakoid membranes and is an inverse function of the number of membranes in the chloroplast - the more membranes, the lower the optical-absorption cross section (Berner et al. 1989). Thus, as cells accumulate chlorophyll, each chlorophyll molecule becomes less effective in light absorption. The so-called "package effect" reduces the effectiveness of increased pigmentation in harvesting light and has important implications for the capital costs of light harvesting (Berner et al. 1989; Kirk 1994 cited in Anthony and Fabricius 2000). 


\subsubsection{Carbon translocation}

Irradiance is the most important environmental parameter for primary productivity, for zooxanthellae as it determines the amount of carbon that can be fixed photosynthetically (Muller-Parker and Davy 2001). The main pathway of carbon fixation remains unclear as there is evidence for both $\mathrm{C}_{3}$ (Hofmann and Kremner 1981) and $\mathrm{C}_{4}$ pathways (Trench and Fisher 1983; Tytler and Trench 1986) however, evidence suggests that the $\mathrm{C}_{3}$ pathway is more likely (Bil et al. 1992; Streamer et al. 1993). The release of fixed carbon to the host is perhaps induced by a "host factor" (a substance or substances residing in the host animals tissues) (Trench 1971; Muscatine et al. 1972; Sutton and Hoegh-Guldberg 1990; Cook and Orlandini 1992), though there is currently no evidence for the operation of this host factor in the intact-association. Translocated carbon is the primary source of energy for the host (Streamer et al. 1993) and is passed on in the form of glucose, glycerol, amino acids and also possibly as lipid (Muscatine 1967; Muscatine et al. 1984; Sutton and Hoegh-Guldberg 1990). Initially, a fraction of the total fixed carbon is used by the zooxanthellae for their own respiration and growth (Trench 1979; Davy et al. 1996). The remainder, estimated to be up to $95 \%$ of the total fixed, is translocated to the host (Muscatine et al. 1983: Muscatine et al. 1984) in support of basal metabolism (Schmitz and Kremner 1977; Crossland et al. 1980; Battey and Patton 1987; Muscatine et al. 1994). Of the carbon translocated, $\sim 80 \%$ is respired (Falkowski et al. 1984) with the remainder used in the release of particulate and dissolved organics, incorporated into the skeletal matrix (in corals), storage (Falkowski et al. 1984; Muscatine et al. 1984), or used for host growth and reproduction (Muscatine et al. 1981; McCloskey et al. 1994).

Symbiotic cnidarians may be considered polytrophic as they obtain nutrition in the form of carbon from both photosynthesis and heterotrophic feeding (Muscatine and 
Porter 1977). For tropical cnidarians, it is generally considered that translocated carbon is often more than enough to satisfy the respiratory needs of the host (Muscatine et al. 1984) resulting in complete autotrophy. However, under a variety of cloud conditions (cloudless, intermittent cloud, heavily overcast) Davies (1991) reports the energy budgets of the corals Pocillopra damicornis, Montipora verrucosa and Porites lobata to not be wholly met by autotrophy, with the deficit met from the lipid stores of the host. Conversely, it is suggested that temperate associations rely on some form of heterotrophy to supplement their carbon demands (Muller-Parker and Davy 2001) such as predation on zooplankton, the uptake of particulate and dissolved organic material from the environment (Lewis and Price 1975), mucus feeding, and feeding on microorganisms associated with detritus and mucus (Muscatine et al. 1984). Temperate species are therefore highly dependent on heterotrophy (Davy et al. 1996). However, this is rarely a problem, for example the temperate North American anemone Anthopleura elegantissima can obtain $2550 \mu \mathrm{g} \mathrm{C}$ per day by feeding heterotrophically (Shick, pers. comms. cited in Verde and McCloskey 1996b). Another example is that of the temperate corals Astrangia danae and Oculina arbuscula that are facultatively symbiotic, as they occur with and without zooxanthellae, implying they can survive by heterotrophy alone (Szmant-Froelich and Pilson 1984).

Estimating the proportion of energy passed from symbiont to host has been traditionally determined by investigating the ratio of maximum photosynthesis ( $\mathrm{P}_{\max }$ gross) over day light hours to dark respiration $\left(\mathrm{R}_{\mathrm{s}}\right)(\mathrm{P}: \mathrm{R}$ ratio) over 24 hours (Davies 1977 cited in Leletkin 2000). If the value of the P:R ratio exceeds 1 , then it is assumed that there is a surplus of photosynthetically fixed carbon available to the whole organism. Alternatively, a value less than 1 indicates the association to only be partially fulfilled photosynthetically (Muscatine et al. 1981). Further development of energy 
budget models has introduced the contribution of translocated carbon to animal respiration requirements (CZAR) (Muscatine et al. 1981). This allows for an estimation of the contribution of zooxanthellae carbon to host respiration. The major components used to estimate the CZAR are photosynthesis, respiration, algal reproduction (cytokinesis), and algal translocation (Verde and McCloskey 1996a). This equation has been applied to a number of associations (e.g. Muscatine et al. 1984; Edmunds and Davies 1989; Davy et al. 1996; Verde and McCloskey 2002) and has revealed that up to $99 \%$ of carbon fixed in photosynthesis (Davy et al. 1996) is translocated to the animal where it can potentially satisfy $100 \%$ of the animal's daily requirements for respiration (Muscatine et al. 1984).

\subsubsection{Nitrogen metabolism}

Nitrogen may be incorporated into the algal-invertebrate association via two pathways. First, nitrogen may be directly taken up as nitrate (Marubini and Davies 1996), ammonium (D'Elia et al. 1983; Wilkerson and Muscatine 1984), or dissolved organic nitrogen from the water column (Ferrier 1991). Second, it has been shown that cnidarians obtain nitrogen through the digestion of prey captured by the host (Lewis and Price 1975; Clayton and Lasker 1984). The retention of nitrogen within the symbiosis is promoted by one of two mechanisms:

(1) Nitrogen recycling involves the bidirectional translocation of nutrients. First, host waste nitrogen is translocated to the zooxanthellae which assimilates the nitrogen compounds via the glutamine synthetase - glutamate synthase (GS/GOGAT) pathway, to a nutritional value to the host (i.e. amino acids) and second, translocates these compounds back to the host (Douglas 1994). Currently, there are no quantitatively reliable estimates of the flux of ammonium derived from animal 
catabolism to zooxanthellae or of the translocation of nitrogen compounds back to the host (Wang and Douglas 1998).

(2) Nitrogen conservation was first proposed by Rees (1986) and Rees and Ellard (1989). They proposed that the utilisation of amino acids as respiratory substrates by the host is reduced by the receipt, from the algal cells, of photosynthetic carbon compounds which are used preferentially in host respiration. The resultant conservation of nitrogenous compounds in the host tissues would promote the persistence of these symbioses in low-nitrogen environments.

\subsection{Temperate vs. tropical symbioses}

The geographic distribution of invertebrate-algal associations differs with thermal and photic regimes. In the Pacific Basin they extend from Alaska $\left(60^{\circ} \mathrm{N}\right)$ to New Zealand $\left(45^{\circ} \mathrm{S}\right)$ (Buddemeier and Fautin 1996 cited in Muller-Parker and Davy 2001) and in the Eastern Atlantic Basin they are observed as far north as Scotland (Muller-Parker and Davy 2001). The majority of cnidarian species are located in the tropics between $25^{\circ} \mathrm{N}$ - $25^{\circ} \mathrm{S}$ (Muller-Parker and Davy 2001). It is here that minimal seasonal variation, resulting in high irradiance and temperature, acts synergistically with low nutrient concentrations to provide favourable conditions for the formation of cnidariandinoflagellate symbioses (Muller-Parker and Davy 2001). Alternatively, in temperate regions, overcast skies, short day lengths, turbid waters, and low temperatures (Shick and Dykens 1984; Farrant et al 1987a, b; Turner 1988 cited in Muller-Parker and Davy 2001) provide conditions for the formation of only a small number of algal-invertebrate symbioses. However, symbioses at these latitudes are regarded as highly robust and tolerant of the extreme environmental conditions that occur (Muller-Parker and Davy 2001). 


\subsubsection{Irradiance}

Irradiance is the most significant factor that controls the productivity, physiology and ecology of symbiotic cnidarians (Porter et al. 1984) and limits their distribution to the photic zone. Irradiance varies with depth, water quality and latitude, and may be modified underwater by the angle of incident light, the absorption and scattering of light by dissolved and particulate matter in the water, and by the water itself (Kirk 1994 cited in Anthony and Fabricius 2000). Consequently, as irradiance is not uniformly attenuated across all wavelengths in shallow waters so called flashes or sunflecks can exceed $4000 \mu \mathrm{mol}$ photons $\mathrm{m}^{-2} \mathrm{~s}^{-1}$ (Falkowski et al. 1990 cited in Anthony and Hoeghguldberg 2003). However, irradiance within the aquatic environment displays high temporal variability over a range of timescales (Anthony and Hoegh-Guldberg 2003). Long term irradiance fluctuations occur seasonally, determined by the solar declination cycle (Kirk 1994 cited in Anthony and Fabricius 2000). Short term fluctuations occur due to cloud variation which may be considered a seasonal component, turbidity caused by re-suspension of bottom sediments through wave action (Larcombe et al. 1995), and tidal cycles which affect the depth of the water column (Anthony et al. 2004). Summer irradiances for tropical and temperate regions may be similar $(1400-1500 \mu \mathrm{mol}$ photons $\mathrm{m}^{-2} \mathrm{~s}^{-1}$ ) but light penetration through the water column is greater in clear tropical waters (Muller-Parker 1987; Turner 1988 cited in Muller-Parker and Davy 2001). In Lough Hyne (Eire), on a bright sunny day anemones receive $546 \mu \mathrm{mol}$ photons $\mathrm{m}^{-2} \mathrm{~s}^{-1}$ compared with Hawaiian anemones receiving $1400 \mu \mathrm{mol}$ photons $\mathrm{m}^{-2} \mathrm{~s}^{-}$

${ }^{1}$ at equivalent depths of $1.5 \mathrm{~m}$ (Muller-Parker 1987; Turner 1988 cited in MullerParker and Davy 2001). Furthermore, at the lower limits of temperate symbiotic cnidarian distribution (21 m depth), anemones may receive $\leq 10 \mu \mathrm{mol}$ photons $\mathrm{m}^{-2} \mathrm{~s}^{-1}$ of the $1500 \mu \mathrm{mol}$ photons $\mathrm{m}^{-2} \mathrm{~s}^{-1}$ surface irradiance (Turner 1988 cited in Muller-Parker 
and Davy 2001). However, the synergistic act of cloud fluctuation, turbidity and tides on weekly to monthly light variations is unclear for the majority of coastal benthic habitats (Anthony et al. 2004).

\subsubsection{Temperature}

Temperature is a major factor controlling the rate of photosynthesis in all plants. Photosynthetic algae occur in the hottest and coldest environments in which autotrophic protists can be found (Davison 1991). Temperate and tropical cnidarians are both exposed to varied thermal regimes. However, seawater temperatures are markedly lower and more varied at temperate latitudes compared to tropical latitudes (MullerParker and Davy 2001). For instance, temperatures at temperate latitudes have been reported to range from $9^{\circ} \mathrm{C}-23^{\circ} \mathrm{C}$ seasonally (Kevin and Hudson 1979; Farrant et al. 1987a; Schiller 1993) and during the summer months inter-tidal temperate cnidarians may experience fluctuations of $10^{\circ} \mathrm{C}$ over the course of a day (Jensen and MullerParker 1994). In contrast, annual temperatures from Jamaica have been recorded at $28.1^{\circ} \mathrm{C} \pm 3^{\circ} \mathrm{C}$ (Webber and Roff 1995 ). Coral reefs typically grow at $18^{\circ} \mathrm{C}-30^{\circ} \mathrm{C}$ (Veron 1986 cited in Hoegh-Guldberg 1999), but below $18^{\circ} \mathrm{C}$ the abundance of hermatypic corals declines and reefs do not form (Hoegh-Guldberg 1999). These temperature comparisons suggest that symbiotic cnidarians, their zooxanthellae or both

exhibit regional differences in temperature tolerance and that tropical symbiotic cnidarians are less tolerant of temperature change (Muller-Parker and Davy 2001). 


\subsection{Symbiosis stability}

Under normal environmental conditions, the maintenance of zooxanthellae within an animal host is balanced by the expulsion and production of new zooxanthellae during mitosis. Typically, zooxanthellae are expelled at a rate of less than $4 \%$ at which new cells are added to the population (Hoegh-Guldberg et al. 1987). Over time these low rates of expulsion/production of cells results in seasonal changes in the population densities of the zooxanthellae (Fitt et al. 2000). Seasonal changes are largely due to variations in the physical environment (e.g. irradiance, temperature) at the present time and occur slowly to optimise the physiological performance of the two-genome syncytium as the environment changes (Hoegh-Guldberg 1999). However, the influence of the physical and chemical environment under extreme conditions can lead to rapid reductions in the population of zooxanthellae within a variety of hosts (HoeghGuldberg and Smith 1989a; Fitt and Warner 1995).

In recent times, symbiotic cnidarians have been affected by a phenomenon known as coral bleaching (Lesser et al. 1996). Bleaching occurs through the loss of symbiotic algae, reduction in chlorophyll $a$ and accessory pigments, or a combination of the two (Hoegh-Guldberg 1999). When cnidarians bleach they may lose $60-90 \%$ of their zooxanthellae and each zooxanthella may lose $50-80 \%$ of its photosynthetic pigments (Glynn 1996). Particular attention has been focused on tropical cnidarians within this field, as they have shown a high degree of susceptibility to bleaching as slight variations in salinity, light and temperature have a dramatic effect on the formation of coral reefs (Hoegh-Guldberg 1999). 


\subsubsection{Salinity}

Tropical corals have been shown to exist at salinities from $32-40$ ppt (Veron 1986 cited in Hoegh-Guldberg 1999) and consequently have low tolerance to salinity fluctuations. Rapid decreases in salinity occurring through freshwater runoff, heavy rain, or flood events may have short term effects through decreases in respiratory and photosynthetic rates (Muthiga and Szmant 1987), while long term losses of chlorophyll $a$ and algal expulsion lead to death (Hoegh-Guldberg and Smith 1989a). Furthermore, fluctuations in salinity are thought to play an important role in limiting the distribution of reef building corals in coastal regions due to the proximity of rivers to coral reefs (Hoegh-Guldberg 1999).

\subsubsection{Ultraviolet radiation (UVR)}

Reduction in stratospheric ozone as a result of anthropogenic inputs has resulted in an increase of ultra-violet radiation (UVR) $(290-400 \mathrm{~nm})$ reaching the sea surface (Lesser 1996). In response, the host and symbiont have a range of protective mechanisms to counteract the direct and indirect influences of UVR. These include the production of mycosporine-like amino acids (MAAs) which are natural sunscreen (UVR blocking) compounds, and a range of active oxygen scavenging systems (Shick et al. 1996). However, effects of exposure to UVR have shown decreased growth rates, chlorophyll a concentrations, carbon:nitrogen ratios, photosynthetic and ribulose biphosphate carboxylase/oxygenase (Rubisco) activities (e.g. Jokiel and York 1982; Shick et al. 1991, 1995; Kinzie 1993; Banaszak and Trench 1995). 


\subsubsection{Temperature}

Temperature has been shown to be an important environmental parameter for algalcnidarian symbiosis (Muscatine et al. 1991; Hoegh-Guldberg 1999). Photosynthetic responses of cnidarians to temperature show that the thermal environment has a strong impact on the photosynthetic apparatus (Davison 1991). This is because rates of photosynthesis and respiration are temperature dependent, and an increase or decrease in ambient seawater temperature can result in an increase or decrease in both photosynthetic and respiration rates (Howe and Marshall 2001; Nakamura et al. 2003). High temperatures result in the breakdown of enzymatic pathways within the photosynthetic apparatus, resulting in biochemical and metabolic dysfunction. The level of stress depends on the length of exposure and the synergistic action of other environmental variables (e.g. light, salinity) (Cossins and Bowler 1987 cited in Fitt et al. 2001).

Numerous sites within the photosynthetic apparatus are sensitive to high temperatures (Warner et al. 1996). Photosystem II (PSII) has been reported to be most sensitive to elevated temperature with high irradiance increasing damage to PSII further through deterioration of the $32 \mathrm{kDa}$ protein $\mathrm{D}_{1}$ (Warner et al. 1999). Reactive oxygen species (ROS) such as hydrogen peroxide $\left(\mathrm{H}_{2} \mathrm{O}_{2}\right)$, hydroxyl radicals $\left(\mathrm{OH}^{-\bullet}\right)$ and superoxide radicals $\left(\mathrm{O}_{2}{ }^{--}\right)$are produced through normal cellular metabolism by the host and by photosynthesis of zooxanthellae (Griffin et al. 2006). As seawater temperature increases and photosynthesis is impacted upon, ROS are produced in greater amounts (Lesser 1996, 1997; Nii and Muscatine 1997) so the cells react by amplifying concentrations of anti-oxidants and the ROS are detoxified. However, if the amount of ROS produced is greater than the rate of detoxification, then ROS can cause oxidative damage by denaturing a variety of cell components such as lipids, nucleic acids and 
proteins (i.e. $\mathrm{D}_{1}$ protein) that make up the photosynthetic apparatus within zooxanthellae (Jones et al. 1998; Asada 1999) and consequently result in bleaching.

\subsubsection{Acclimation vs. adaptation}

Many studies document elevated temperature as the cause of mass bleaching events (Coles and Jokiel 1977, 1978; Glynn and D’Croz 1990; Lesser et al. 1990). In 1998, more than $16 \%$ of the world's tropical coral reefs were seriously damaged by bleaching, with $50-90 \%$ mortality in some areas (Wilkinson 2002 cited in Smith et al. 2005). Climate change models predict a $1.8^{\circ} \mathrm{C}-4^{\circ} \mathrm{C}$ increase in temperatures for tropical regions over the next century (IPCC 2007 cited in Hoegh-Guldberg et al. 2007), which is likely to result in more frequent and more severe mass bleaching events. For corals to survive long-term they must acclimate or adapt with the rate of change (Hoegh-Guldberg 2004). Acclimatisation in corals can take the form of a change in the physiology of the host as well as a change in the relative proportion of symbiont types in the host (Baker 2004; Coles and Brown 2003; Rowan 2004). Adaptation requires selective mortality of less thermally tolerant individuals or differential reproductive success and provides a genetic basis for a change in tolerance. Buddemeier and Fautin (1993) proposed the "adaptive bleaching hypothesis" (ABH). This hypothesis suggests that changing combinations of hosts and zooxanthellae have the potential to create new ecospecies that differ in environmental tolerances. The diversity and flexibility of symbiotic associations within an animal host, occurring over small spatial scales and short (single generation) time scales, could explain differences from one coral population to another. 


\subsection{Anthopleura aureoradiata}

Anthopleura aureoradiata (Fig 1.2), the mudflat anemone, is a common inter-tidal anemone found throughout New Zealand, from Stewart Island to Cape Reinga (Phillips 2006), inhabiting mud-flat and rocky inter-tidal environments. On mudflats, $A$. aureoradiata is commonly found attached to the cockle, Austrovenus stutchburyi, burrowed an inch or so below the surface of the mud-flat. A. aureoradiata residing on cockles may reduce the rate at which cockles accumulate trematode parasites in the field, suggesting a non-obligate mutualistic association between the anemone and cockle (Mouritsen and Poulin 2003). During high tide or in shallow pools of water during low tide, A. aureoradiata may be seen with its oral disc and tentacles displayed above the surface of the mudflat. However, at other times, A. aureoradiata remains retracted beneath the surface even when water is present above; perhaps as a result of sun exposure, turbidity or windy conditions. Alternatively, A. aureoradiata found inhabiting the rocky inter-tidal zone may be found within cracks and crevices attached to rocks within tide pools and hence may be subjected to aerial exposure for long periods of time during low tide, yet at high tide it is completely submerged.

This temperate species provides a good model organism to investigate the photobiology and function of the symbiosis under different environmental regimes and diverse habitats. The stability of this symbiosis is seen to be highly robust as it has never been seen to bleach, even in high shore rock pools during summer and therefore is also a good model organism to investigate thermal stability in temperate symbiosis. 


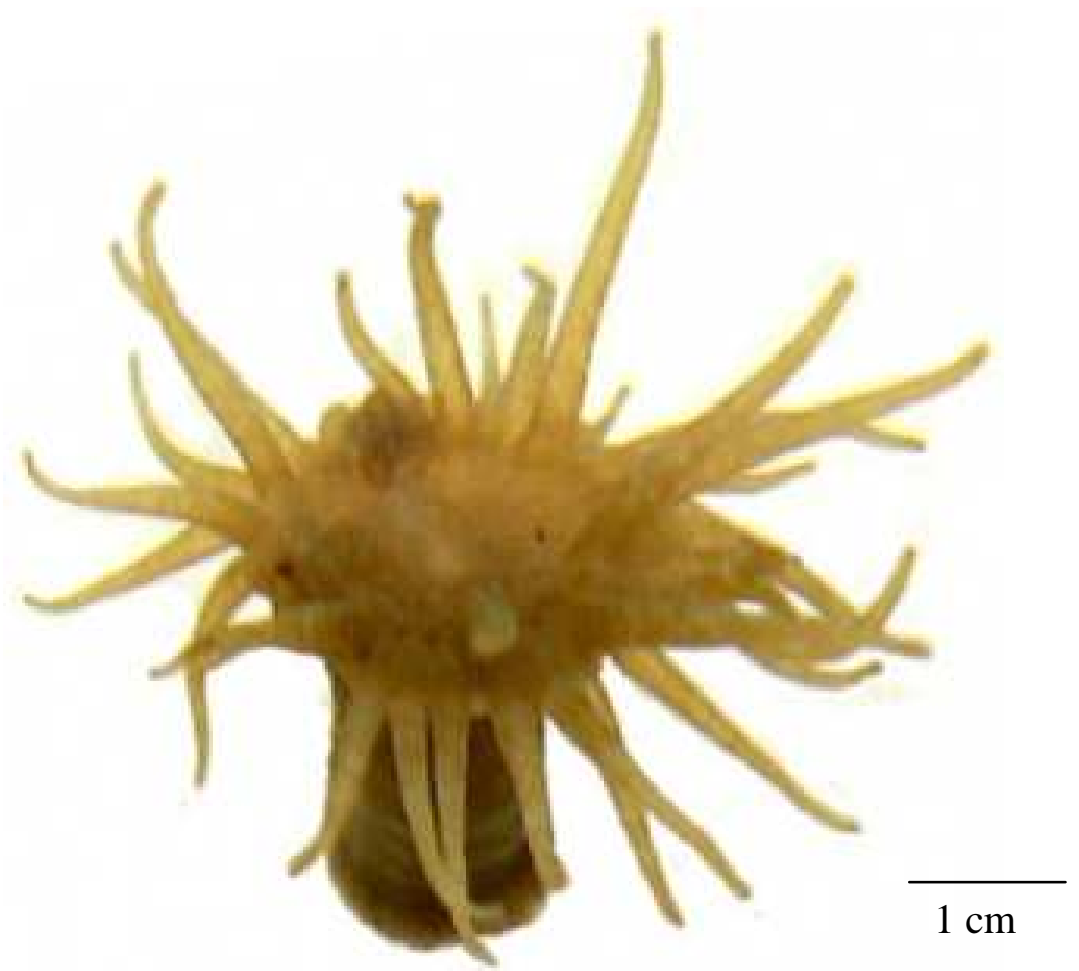

Figure 1.2. Anthopleura aureoradiata with tentacles full expanded.

\subsection{Aims}

The aim of this study was to determine the potential autotrophy under a variety of irradiance and thermal regimes in a temperate algal-cnidarian symbiosis by constructing carbon budgets for A. aureoradiata.

In particular, this study:

1. Determined the photosynthetic abilities for A. aureoradiata from mud flat and rocky shore habitats, during summer and winter, on sunny and cloudy days, and determined the potential for autotrophy under these conditions

2. Determined the thermal thresholds for photosynthetic function, when exposed to gradual temperature and rapid temperature changes. Additionally, the potential for autotrophy under these temperature exposures was determined. 


\section{Chapter 2:}

\section{Carbon flux in the symbiotic inter-tidal sea anemone Anthopleura aureoradiata.}

\subsection{Introduction}

Cnidaria and their endosymbiotic dinoflagellates ("zooxanthellae") are thought to have a mutualistic relationship (Trench 1979, 1987). In return for fixed carbon, zooxanthellae receive waste products from its host which are high in nitrogen and phosphorus (Dubinsky and Jokiel 1994). It is estimated that $>95 \%$ of total fixed carbon is translocated to the host (Muscatine et al. 1983; Muscatine et al. 1984). Initially, a fraction is utilized by the zooxanthellae for their own respiration and growth (Sharp 1977; Trench 1979) with the remainder translocated largely in the form of glycerol and glucose for the support of basal metabolism of the host (Schmitz and Kremner 1977; Battey and Patton 1987; Muscatine et al. 1994).

The significance of translocated carbon to the host has been reported in a number of algal-invertebrate associations (e.g. Muscatine et al. 1984: Davies 1991; Verde and McCloskey 2007). For tropical cnidarian species, translocated carbon is, on sunny days, more than enough to satisfy the respiratory needs of the host (Muscatine et al. 1984) resulting in complete autotrophy. Conversely, for temperate species, photosynthesis alone cannot meet the demands of respiration and the host must rely on some form of heterotrophic feeding to supplement its energy demands (Muscatine et al. 1984). This may occur through predation on zooplankton, uptake of particulate and dissolved organic material from the environment (Lewis and Price 1975), mucus 
feeding, and feeding on micro-organisms associated with detritus and mucus (Muscatine et al. 1984). Nevertheless, the ability of a zooxanthellate cnidarian to compensate for decreased photosynthesis via increased heterotrophy is most likely species specific (Anthony and Fabricius 2000).

The photosynthetic capability of zooxanthellate cnidarians is habitat dependent (Falkowski et al. 1984). Photosynthetic measurements show tropical species to be more productive than temperate species, at saturating irradiance. Yet, temperate species are known to have a higher photosynthetic efficiency resulting in greater use of low light (Davy et al. 1996). This occurs by photoacclimation, a biochemical response to an increase in the relative quantum yield of photosynthesis (Leletkin et al. 1980) and occurs by an increase or decrease in zooxanthellar density, size and pigment content, relative to the observed light intensity (e.g. Titlyanov et al. 1980, 2000; Fricke and Meischner 1985; Muller-Parker 1987)

At tropical latitudes, low nutrient concentrations coincide with modest seasonal variability resulting in minimal variation in irradiance and temperature, providing favourable conditions for the formation of cnidarian symbioses (Muller-Parker and Davy 2001). Alternatively, in temperate regions, overcast skies, short day lengths, turbid waters, and low temperatures (Shick and Dykens 1984; Farrant et al. 1987a, b; Turner 1988 cited in Muller-Parker and Davy 2001) provide conditions for the formation of only a small number of algal-invertebrate associations. Although, symbioses at these latitudes are regarded as highly robust and tolerant of the extreme environmental conditions that occur (Muller-Parker and Davy 2001).

Many studies investigating invertebrate-algal associations have focused on tropical species (Porter et al. 1984; Stimson 1997; Brown et al. 1999), while temperate studies have focused in particular on the North American sea anemone Anthopleura 
elegantissima (McCloskey et al. 1996; Saunders and Muller-Parker 1997; Verde and McCloskey 2007) and to a lesser extent the European anemone Anemonia viridis (Davy et al. 1996). This study presents the first detailed description of the temperate symbiotic sea anemone Anthopleura aureoradiata under field conditions, by addressing the following:

1. How does season affect the algal density and growth rate?

2. How do season, cloud cover and habitat affect the photophysiology of $A$. aureoradiata?

3. How do season, cloud cover and habitat affect the contribution of zooxanthellae to the animal's respiratory requirements (CZAR) in $A$. aureoradiata? 


\subsection{Materials and methods}

\subsubsection{Study species}

The temperate symbiotic sea anemone Anthopleura aureoradiata (formerly Bunodes aureoradiata) (Fig. 2.1A) is common throughout New Zealand's inter-tidal zone (Phillips 2006). It is one of several anemone species inhabiting mud-flat environments (Morton and Miller 1968), though the only one to contain zooxanthellae, that are thought to belong to the genus Symbiodinium within Clade A (Phillips 2006) (Fig 2.1B). Within the mud flat, A. aureoradiata is found residing upon the cockle Austrovenus stuchburyi (Fig 2.2D) and occasionally upon cockle shell debris, rocks, oysters, mangrove roots and within the strands of algae (Phillips 2006). A. aureoradiata residing on cockles may reduce the rate at which cockles accumulate trematode parasites in the field, suggesting a non-obligate mutualistic association between the anemone and cockle (Mouritsen and Poulin 2003). At high tide or in shallow pools of water during low tide, A. aureoradiata may be seen above the surface of the mudflat with its oral disc and tentacles displayed (Fig 2.2C) (Gibbons, personal observation). Within the rocky inter-tidal zone, A. aureoradiata may be found in cracks and crevices, typically residing in small groups (Fig 2.2F). At high tide A. aureoradiata is completely submerged, while during low tide it may be subjected to aerial exposure for hours at a time. 


\subsubsection{Field and collection sites}

Two distinct field sites were chosen within the Wellington region. First, Pauatahanui Inlet (Fig. 2.2B) is a soft shore tidal estuary situated on the west coast of the North Island, $20 \mathrm{~km}$ north of Wellington city. The estuary is approximately $3.5 \mathrm{~km}$ long by 2 $\mathrm{km}$ wide. Second, Kau Bay (Fig. 2.2E), located on the Miramar Peninsula of

Wellington's south coast, is predominantly rocky, derived from greywacke and associated argillite sediments.
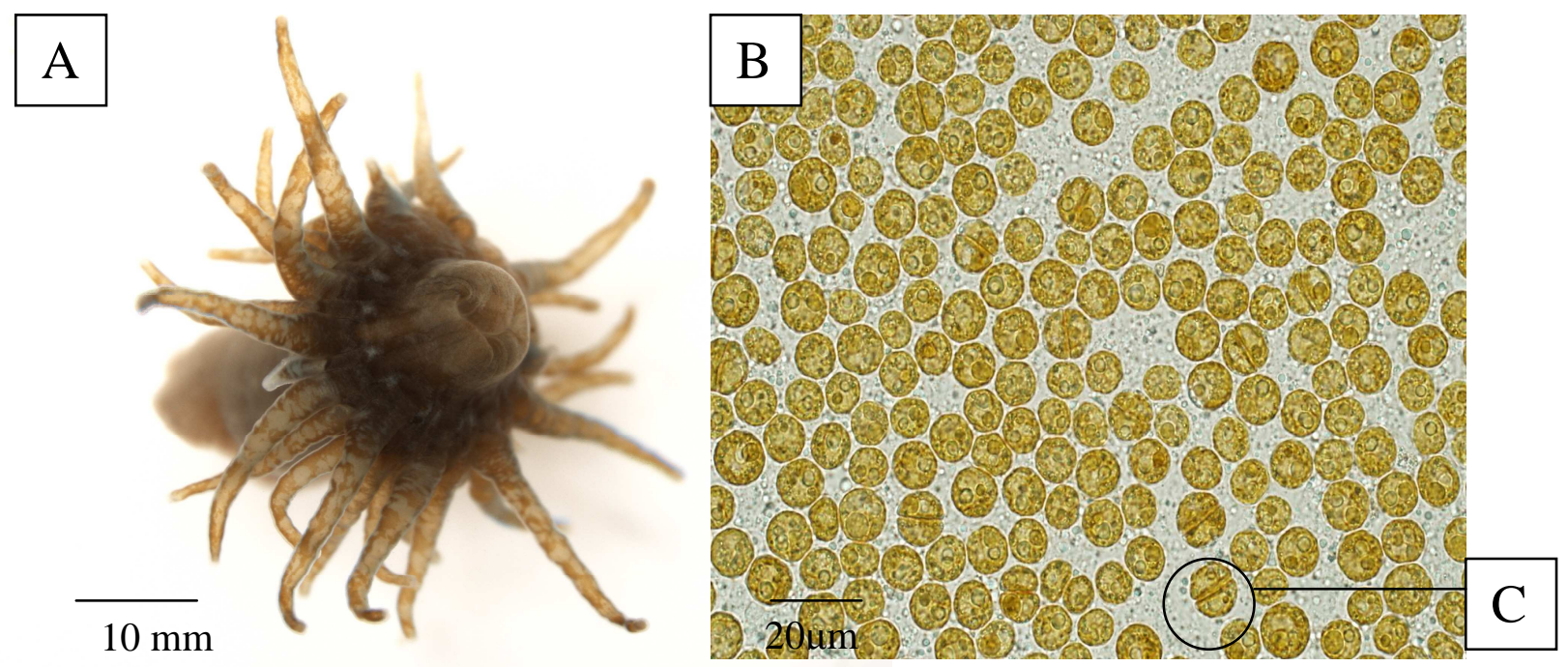

Figure 2.1. (A) Anthopleura aureoradiata with tentacles exposed to irradiance. (B) Zooxanthellae residing within A. aureoradiata. (C) A dividing zooxanthella appearing as a doublet. 


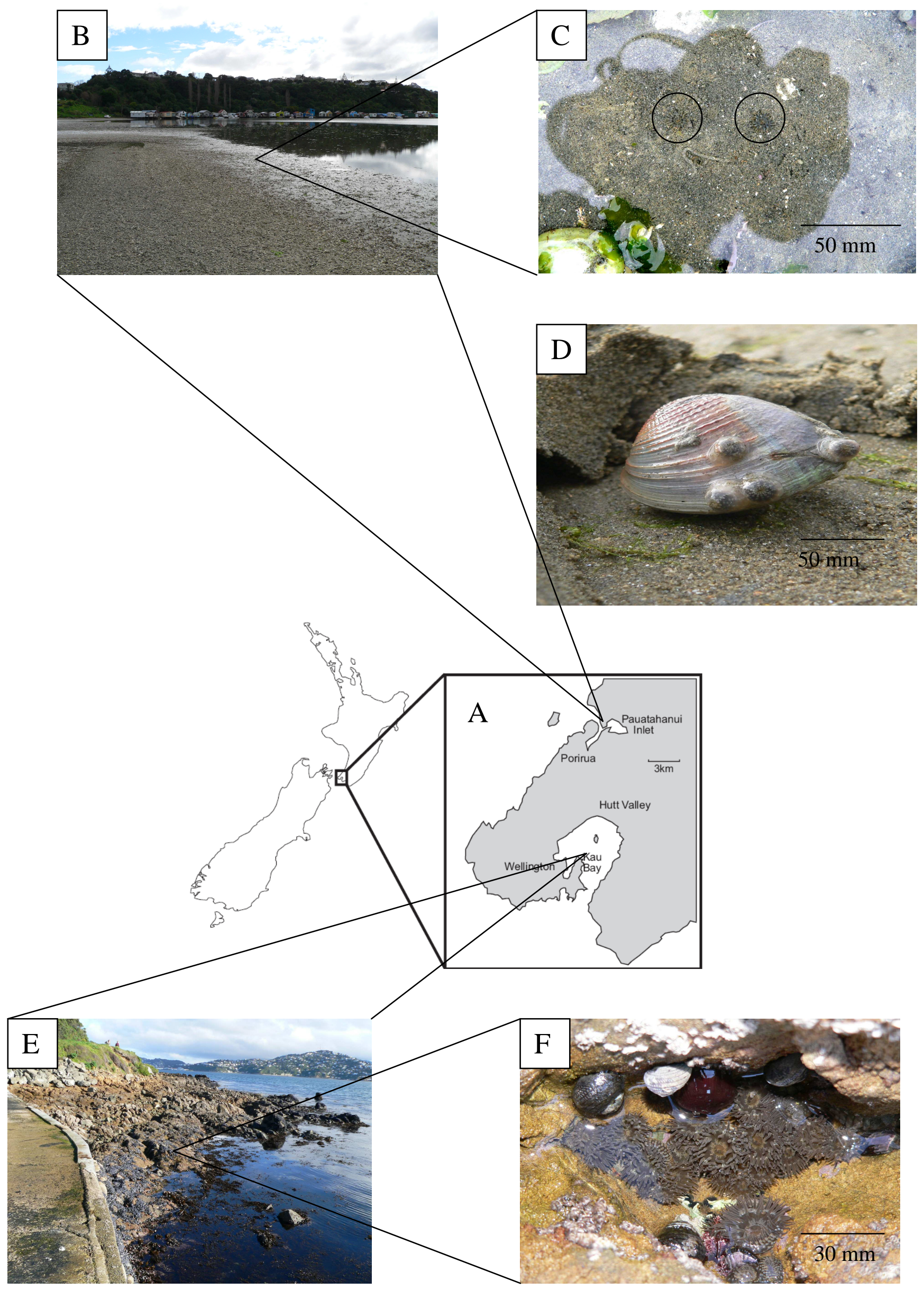

Figure 2.2 (A) Map of New Zealand indicating field sites within the Wellington Region. (B) Low tide at Pauatahanui Inlet. $(\boldsymbol{C})$ Anthopleura aureoradiata at the surface of the sediment at low tide (water depth $<5 \mathrm{~mm}$ ). (D) Four individuals of $A$. aureoradiata attached to a cockle shell (Austrovenus stutchburyi) newly excavated from the sediment. (E) Low tide at Kau Bay. (F) Aggregation of A. aureoradiata individuals attached to rocks in the midlittoral zone. 


\subsubsection{Environmental parameters}

Environmental parameters were measured to model the contribution of translocated zooxanthellar carbon to the animal's daily respiratory requirements (CZAR) (Muscatine et al. 1981). Environmental parameter recordings were taken hourly from first light to last light over a day, and included measurements of solar irradiance $\left(\mu \mathrm{mol}\right.$ photons $\mathrm{m}^{-2} \mathrm{~s}^{-}$

$\left.{ }^{1}\right)$ (LI-COR LI-1000 irradiance data logger), salinity (ppt), air temperature $\left({ }^{\circ} \mathrm{C}\right)$, water temperature $\left({ }^{\circ} \mathrm{C}\right)$, mud temperature $\left({ }^{\circ} \mathrm{C}\right)$ (Pauatahanui Inlet only), cloud cover $(\%$ determined by eye) and rain ("light", "moderate", "heavy"). At Pauatahanui Inlet, recordings were taken $50 \mathrm{~m}$ from shore at 3 locations, approximately $25 \mathrm{~m}$ away from each other. At Kau Bay recordings were taken at four different rock pools, two north facing and two south facing, in the mid-littoral zone. Measurements were taken at Pauatahanui Inlet on January $3^{\text {rd }}, 4^{\text {th }}$ and $10^{\text {th }} 2007$ during summer and July $8^{\text {th }}, 9^{\text {th }}, 10^{\text {th }}$ and $11^{\text {th }} 2007$ during winter on both sunny and cloudy days. At Kau Bay measurements were taken on December $28^{\text {th }}, 29^{\text {th }}, 31^{\text {st }} 2006$ and January $9^{\text {th }} 2007$ during summer and July $5^{\text {th }}, 6^{\text {th }}$ and August $5^{\text {th }} 2007$ during winter on both sunny and cloudy days.

\subsubsection{Photosynthesis-irradiance relationships}

Oxygen flux of $A$. aureoradiata (Fig 2.3) was measured for 4 anemones simultaneously in a clear glass cylindrical chamber $(\sim 14 \mathrm{ml}$ volume), situated in a clear Perspex, temperature controlled water bath. The glass chamber contained $1-\mu \mathrm{m}$ filtered seawater (FSW), with a magnetic spin bar gently stirring the water inside the chamber to provide a homogeneous distribution of dissolved oxygen; the spin bar spun at a rate where the anemones did not appear stressed. The spin bar was overlaid by a perforated plastic floor and a layer of nylon mesh, on which the anemones were placed. The chamber was situated on top of an underwater magnetic stirrer (Variomag Compact). The chamber was 
sealed with a rubber bung, into which two holes were drilled, and oxygen and temperature sensors inserted; these were connected to a Fibox 3 temperaturecompensated oxygen meter, linked to a laptop which used the Fibox 3 computer software as a chart recorder. Calibration of the oxygen and temperature sensors involved preparation of oxygen free FSW $(0 \%)$ using $1 \mathrm{~g}$ sodium sulphite $\left(\mathrm{Na}_{2} \mathrm{SO}_{3}\right)$ per $100 \mathrm{ml}$ FSW, and stirring for $30 \mathrm{sec}$. Alternatively, preparation for air saturated FSW (100\%) involved using an air pump to blow air into $100 \mathrm{ml}$ of FSW for $20 \mathrm{~min}$. The chamber was illuminated by a halogen dichroic PAR (photosynthetically active radiation) $12 \mathrm{~V} 50 \mathrm{~W}$ $13^{\circ}$ lamp. Irradiance incident on the anemones was measured using a cylindrical clear perspex chamber (as the light meter probe was not able to fit into the smaller glass chamber) situated in the water bath and a LI-COR LI-1000 irradiance data logger.

Environmental field conditions prior to a laboratory measurement had to consist of a minimum of four hours of sunny or cloudy weather. On this basis, anemones were collected at $1400-1500 \mathrm{~h}$ during winter and $1200-1300 \mathrm{~h}$ during summer from Kau Bay and Pauatahanui Inlet during low tide. Anemones were brought back to the laboratory and debris (e.g. shell, sediment) removed from them. Anemones were then placed upwards on the mesh, in $10 \mathrm{ml} \mathrm{FSW}$ and allowed to settle for approximately 60 min at the appropriate temperature for a sunny or cloudy day (Table 2.3), 35 ppt salinity and a irradiance of $100 \mu \mathrm{mol}$ photons $\mathrm{m}^{-2} \mathrm{~s}^{-1}$.

Following the settlement period, the water inside the chamber was replaced with $100 \% \mathrm{O}_{2}$ saturated water of the same temperature, and the respiration rate $\left(\mathrm{ml} \mathrm{O}_{2} \mathrm{~h}^{-1}\right)$ of the anemones measured in darkness for 45 minutes. The PAR lamp was then switched on and the rate of net photosynthesis measured from $20-200 \mu$ mol photons $\mathrm{m}^{-2} \mathrm{~s}^{-1}$ (in 20 $\mu$ mol photons $\mathrm{m}^{-2} \mathrm{~s}^{-1}$ increments), $200-400 \mu \mathrm{mol}$ photons $\mathrm{m}^{-2} \mathrm{~s}^{-1}$ (in $40 \mu \mathrm{mol}$ photons $\mathrm{m}^{-}$ $2 \mathrm{~s}^{-1}$ increments) and $400-900 \mu \mathrm{mol}$ photons $\mathrm{m}^{-2} \mathrm{~s}^{-1}$ (in $100 \mu \mathrm{mol}$ photons $\mathrm{m}^{-2} \mathrm{~s}^{-1}$ 
increments). Photosynthesis at each irradiance was measured until a constant rate was attained, typically within $10 \mathrm{~min}$.

Upon completion of a photosynthesis - irradiance (P-I) measurement, anemones were homogenised in a hand-held glass tissue grinder containing $10 \mathrm{ml} \mathrm{FSW.} \mathrm{The}$ resulting slurry was centrifuged in a $10 \mathrm{ml}$ centrifuge tube at $2355 \mathrm{x} \mathrm{g}$ for $5 \mathrm{~min}$. The anemone/animal portion (i.e. the supernatant) was decanted into a $20 \mathrm{ml}$ measuring cylinder. Another $10 \mathrm{ml}$ of FSW was then placed in the centrifuge tube and centrifuged at $2355 \mathrm{x}$ g for $5 \mathrm{~min}$. The supernatant was again decanted into the measuring cylinder. From this cylinder, $1.5 \mathrm{ml}$ of animal supernatant was pipetted into a $1.5 \mathrm{ml}$ Eppendorf tube $(\mathrm{n}=2)$ and frozen at $-20^{\circ} \mathrm{C}$ to be analysed for protein concentration at a later date. Zooxanthellae remaining in the centrifuge tube were resuspended in $10 \mathrm{ml} \mathrm{FSW.} \mathrm{A}$ subsample $(200 \mu \mathrm{l})$ of the zooxanthella suspension was pipetted onto a haemacytometer and the number of zooxanthellae counted ( $n=10$ counts per sample), and averaged. These counts were ultimately used for the calculation of zooxanthellar density (i.e. number of zooxanthellae per mg host protein). 


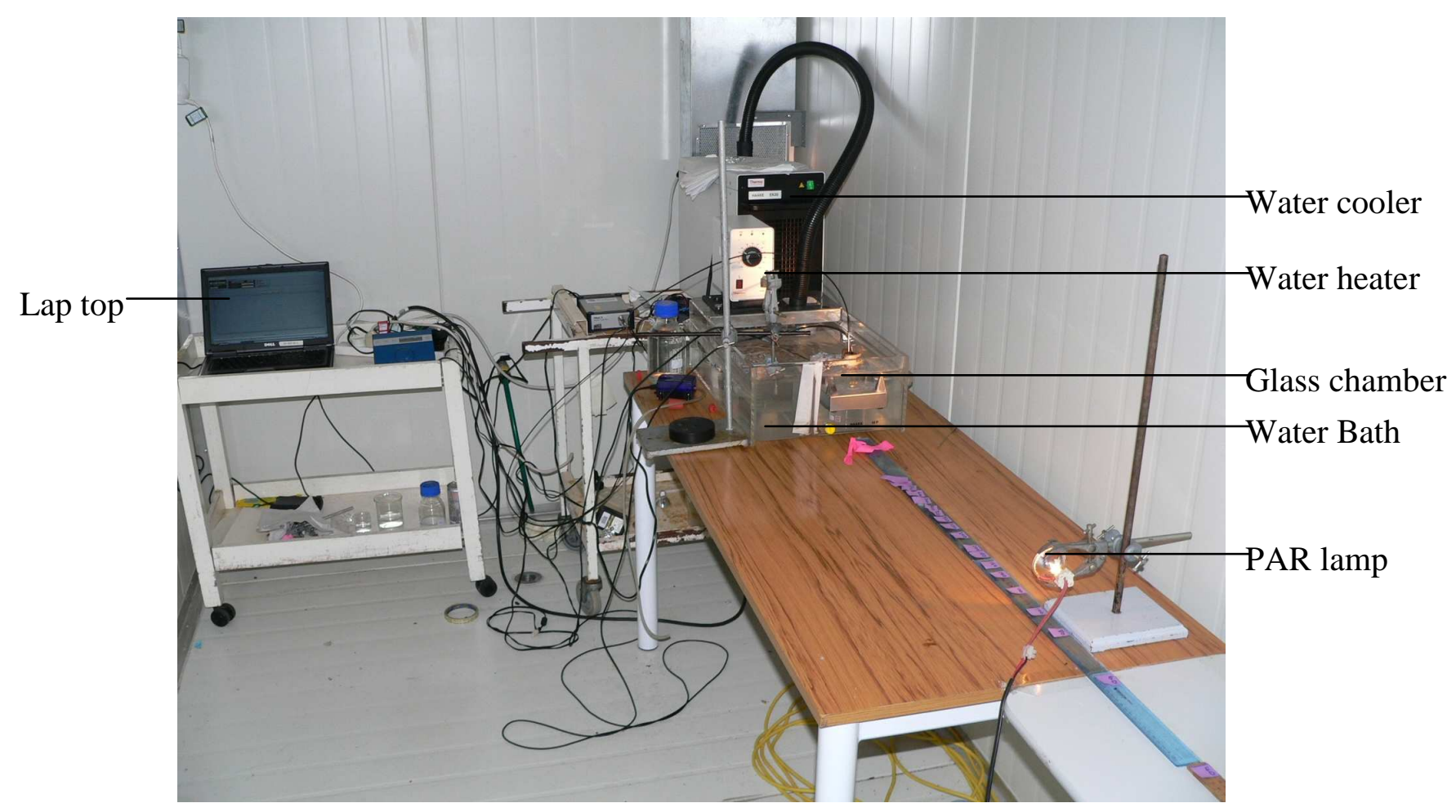

Figure 2.3. $\mathrm{O}_{2}$ flux setup for photosynthesis/irradiance measurements, showing the lap top, water cooler, water heater, glass chamber containing anemones, water bath and the PAR lamp. The PAR lamp was moved progressively closer to the chamber in order to increase irradiance.

\subsubsection{Protein analysis}

Anemone protein was assayed according to a modification of the Lowry procedure (Shakir et al. 1994). A standard curve was generated using specified concentrations of bovine serum albumen (BSA) (Table 2.1). To this, $1 \mathrm{ml}$ of alkaline copper sulphate solution (containing $19.6 \mathrm{~g} \mathrm{Na}_{2} \mathrm{CO}_{3}, 3.92 \mathrm{~g} \mathrm{NaOH}$, $0.097 \mathrm{~g} \mathrm{CuSO}_{4}, 0.198 \mathrm{~g} \mathrm{KNaC}_{4} \mathrm{H}_{4} \mathrm{O}_{6}$ dissolved in $1 \mathrm{~L}$ of distilled water) was added and vortexed for $5 \mathrm{~s}$. Samples were heated to and maintained at $37^{\circ} \mathrm{C}$ for $3 \mathrm{~min}$, before adding $100 \mu \mathrm{l}$ of Folin Ciocalteau's Phenol reagent (Sigma) and vortexed for $5 \mathrm{~s}$ before heating for a further $3 \mathrm{~min}$ at $37^{\circ} \mathrm{C}$. Samples were then centrifuged at $14000 \mathrm{x} \mathrm{g}$ for $3 \mathrm{~min}$ to remove precipitate. The absorbance of samples was measured using a Nicolet Evolution 300 spectrophotometer set at $750 \mathrm{~nm}$, and the protein concentration of samples estimated from the standard curve. 
Table 2.1. Specified concentrations of bovine serum albumen (BSA) to generate a standard curve.

\begin{tabular}{c|cccc}
\hline $\begin{array}{c}\text { Diluted BSA or } \\
\text { anemone protein }\end{array}$ & $\begin{array}{c}\text { Protein concentration } \\
(\mu \mathrm{g} / \mathrm{ml})\end{array}$ & $\begin{array}{c}\text { Protein } \\
(\mu \mathrm{l})\end{array}$ & $\begin{array}{c}\text { FSW } \\
(\mu \mathrm{l})\end{array}$ & $\begin{array}{c}\text { Final volume } \\
(\mu \mathrm{l})\end{array}$ \\
\hline BSA & 0 & 0 & 300 & 300 \\
BSA & 10 & 15 & 285 & 300 \\
BSA & 20 & 30 & 270 & 300 \\
BSA & 40 & 60 & 240 & 300 \\
BSA & 60 & 90 & 210 & 300 \\
BSA & 80 & 120 & 180 & 300 \\
BSA & 100 & 150 & 150 & 300 \\
Anemone & $*$ & 10 & 290 & 300 \\
\hline
\end{tabular}

*calculated from the standard curve

\subsubsection{Determination of mitotic index (MI)}

Diel mitotic activity was measured to determine the growth rate of zooxanthellae from Kau Bay and Pauatahanui Inlet during summer and winter, on a average sunny and cloudy day. Specimens of $A$. aureoradiata $(\mathrm{n}=100)$ were collected on the same day of analysis from Kau Bay and Pauatahanui Inlet. Individuals of A. aureoradiata residing on the cockle (A. stutchburyi) were collected from Pauatahanui Inlet and placed in a $10 \mathrm{~cm}$ deep bowl, covered with a $5 \mathrm{~cm}$ layer of mud and a $2 \mathrm{~cm}$ layer of unfiltered seawater, and exposed to the ambient diurnal regime over the $24 \mathrm{~h}$ sampling period during summer and $12 \mathrm{~h}$ sampling period during winter. Specimens of $A$. aureoradiata collected from Kau Bay were left on rocks and placed in a bucket of seawater, and also maintained under natural light for $24 \mathrm{~h}$ during summer and $12 \mathrm{~h}$ during winter. Sampling of the MI occurred every $3 \mathrm{~h}$, whereby a tentacle from A. aureoradiata was snipped off and smeared across a slide, with a drop of FSW and a coverslip placed on top. A cell was considered dividing (i.e. undergoing mitosis) if it appeared as a doublet with a cell plate (Fig 2.1C) x 100, when observed at magnification. The dividing cells in five samples 
each of 300 cells were averaged and the resultant percentage taken as the MI for each anemone (Wilkerson et al. 1983).

\subsubsection{Contribution of zooxanthellae to animal respiration (CZAR)}

The contribution of zooxanthellae to animal respiration (CZAR) was calculated from $\mathrm{O}_{2}$ flux values according to Muscatine et al. (1981, 1983) (see Appendix A for details). Hourly irradiances recorded from Kau Bay and Pauatahanui Inlet were averaged to give a mean hourly irradiance for the day. The rate of $\mathrm{P}$ (gross) for this average irradiance was derived from P - I curves, and then multiplied by the total number of daylight hours to obtain total $\mathrm{P}$ (gross) for the day. Algal respiration, derived by assuming that animal and algal respiration rates are proportional to their relative biomass (see Appendix A) over 24 $h$ was subtracted from this daily $\mathrm{P}($ gross $)$ to estimate $\mathrm{P}_{\mathrm{z}}$ (net):

Equation 2.1: $\mathrm{P}_{\mathrm{Z}}$ (net) $=\mathrm{P}($ gross $)($ natural light hours $)-\mathrm{R}_{\mathrm{z}}(24$ hours $)$

Where $\mathrm{P}_{\mathrm{z}}($ net $)=$ net zooxanthellar photosynthesis over natural light hours, $\mathrm{P}($ gross $)=$ $\mathrm{P}\left(\right.$ net) $+\mathrm{R}_{\mathrm{s}}$ (whole symbiosis respiration) and $\mathrm{R}_{\mathrm{z}}=$ algal respiration over $24 \mathrm{~h}$ and is subtracted due to the 24 hourly nature of the translocation estimate. 
Daily $\mathrm{P}_{\mathrm{z}}($ net) was then used to calculate the CZAR over $24 \mathrm{~h}$ :

Equation 2.2 $\mathrm{CZAR}=\underline{\mathrm{P}_{\mathrm{z}}(\text { net }) \times \mathrm{T}}$

Where $\mathrm{T}=$ translocation, assumed to be all fixed carbon not used for respiration and growth by the zooxanthellae (see Appendix $A$ for details) and $\mathrm{R}_{\mathrm{a}}=$ animal respiration (i.e. the amount of total respiration not attributable to $\mathrm{R}_{\mathrm{z}}$ ). As a result, the CZAR was calculated for an "average" cloudy and sunny day, in both winter and summer at Pauatahanui Inlet (mudflat) and Kau Bay (rocky shore).

\subsubsection{Statistical analysis}

All statistical analysis was carried out with SPSS@ 14.0 for Windows. Two sample TTests were performed between different sites, day type and seasons for the photosynthetic parameters $\alpha, I_{c}, I_{k}$, cell specific $P_{\max }$ gross and $P_{\max }$ gross (all defined in Table 2.2), respiration, and the zooxanthellar parameters algal density and mitotic index. To reduce the effect of a Type I error the significance level (0.05) was corrected by the Bonferroni correction, to a new level of 0.004 (i.e. 0.05/12). One-way ANOVA was used to determine if algal cell division, over 24 hours during summer and 12 hours during winter, was asynchronous.

Regression lines fitted to photosynthesis - irradiance curves were carried out using Sigmaplot version 8.02. Regression lines of Platplus-beta and Platminus-beta were fitted to data depending on which line fitted the data best. 
Table 2.2. Definitions of the photosynthetic parameters of $\alpha, I_{c}, I_{k}$, cell specific $P_{\max }$ gross and $\mathrm{P}_{\max }$ gross.

\begin{tabular}{|c|l|}
\hline $\begin{array}{c}\text { Photosynthetic Parameter } \\
\boldsymbol{\alpha}\end{array}$ & \multicolumn{1}{c|}{ Definition } \\
\hline $\begin{array}{c}\text { (The initial slope of the P - I curve) } \\
\mathbf{I}_{\mathbf{c}}\end{array}$ & $\begin{array}{l}\text { An estimate of the photosynthetic efficiency } \\
\text { of the zooxanthellae. }\end{array}$ \\
\hline $\begin{array}{c}\text { The irradiance at which there is no net oxygen } \\
\text { flux. }\end{array}$ \\
\hline $\begin{array}{c}\text { (The compensation irradiance) } \\
\text { (Th\% saturation irradiance) }\end{array}$ & $\begin{array}{l}\text { The lowest irradiance at which light saturated } \\
\text { rates of photosynthesis are attained. }\end{array}$ \\
\hline $\begin{array}{c}\text { Cell specific } \mathbf{P}_{\text {maxgross }} \text { maximum photosynthetic rate } \\
\text { per zooxanthellar cell) }\end{array}$ & $\begin{array}{l}\text { A measure of the photosynthetic capacity of a } \\
\text { zooxanthella cell at photosynthetically } \\
\text { saturating irradiances. }\end{array}$ \\
\hline $\begin{array}{c}\mathbf{P}_{\text {max }} \text { gross } \\
\text { (The maximum photosynthetic rate) }\end{array}$ & $\begin{array}{l}\text { A measure of the photosynthetic capacity of } \\
\text { the whole zooxanthella populations at } \\
\text { photosynthetically saturating irradiances. }\end{array}$ \\
\hline
\end{tabular}




\subsection{Results}

\subsubsection{Environmental parameters}

\subsubsection{Irradiance}

Irradiance during summer and winter at Kau Bay and Pauatahanui Inlet on sunny and cloudy days is shown in Fig. 2.4. The maximum irradiance during summer at Kau Bay was $1651 \mu \mathrm{mol}$ photons $\mathrm{m}^{-2} \mathrm{~s}^{-1}$ (Fig. 2.4A) and for Pauatahanui Inlet $1614 \mu \mathrm{mol}$ photons $\mathrm{m}^{-2} \mathrm{~s}^{-1}$ (Fig. 2.4C). The maximum irradiance during winter at Kau Bay was $1160 \mu \mathrm{mol}$ photons $\mathrm{m}^{-2} \mathrm{~s}^{-1}$ (Fig. 2.4B) and for Pauatahanui Inlet $795 \mu \mathrm{mol}$ photons $\mathrm{m}^{-2} \mathrm{~s}^{-1}$ (Fig. 2.4D).

\subsubsection{Temperature}

Temperature varied between season, cloud cover and habitat (Fig. 2.5). Temperature variability appeared greater on a sunny day in comparison with a cloudy day. At Kau Bay, rock pool temperatures during summer on a sunny day were lowest at $0530\left(13.1^{\circ} \mathrm{C}\right)$ and warmest by $1530\left(17.3^{\circ} \mathrm{C}\right)$ (Fig. $\left.2.5 \mathrm{~A}\right)$. On a cloudy day the temperature rose from a low of $12.9^{\circ} \mathrm{C}$ at 0730 to $15.9^{\circ} \mathrm{C}$ by 1530 . At Pauatahanui Inlet, during summer on a sunny day temperature increased from $9.8^{\circ} \mathrm{C}$ at 0530 to $21.8^{\circ} \mathrm{C}$ by 1630 , whereas on a cloudy day the lowest temperature occurred at $0530\left(14.6^{\circ} \mathrm{C}\right)$ and the warmest at 1430 $\left(16.9^{\circ} \mathrm{C}\right)($ Fig. $2.5 \mathrm{C})$.

In contrast to summer temperatures, winter temperatures at Kau Bay peaked at $11^{\circ} \mathrm{C}$ at 1230 on a sunny day from a low of $6^{\circ} \mathrm{C}$ at 0730 (Fig. 2.5B). On a cloudy day the temperature peaked at $10.2^{\circ} \mathrm{C}$ at 1030 before reaching a low of $8.4^{\circ} \mathrm{C}$ at 1630 . At Pauatahanui Inlet during winter, the temperature during a sunny day began at a low of 
$4.8^{\circ} \mathrm{C}$ at 0730 and increased to a high of $12^{\circ} \mathrm{C}$ at 1330 (Fig. 2.5D). On a cloudy day temperatures rose from $6.4^{\circ} \mathrm{C}$ at 0730 and reached a high of $9.2^{\circ} \mathrm{C}$ by 1330 .
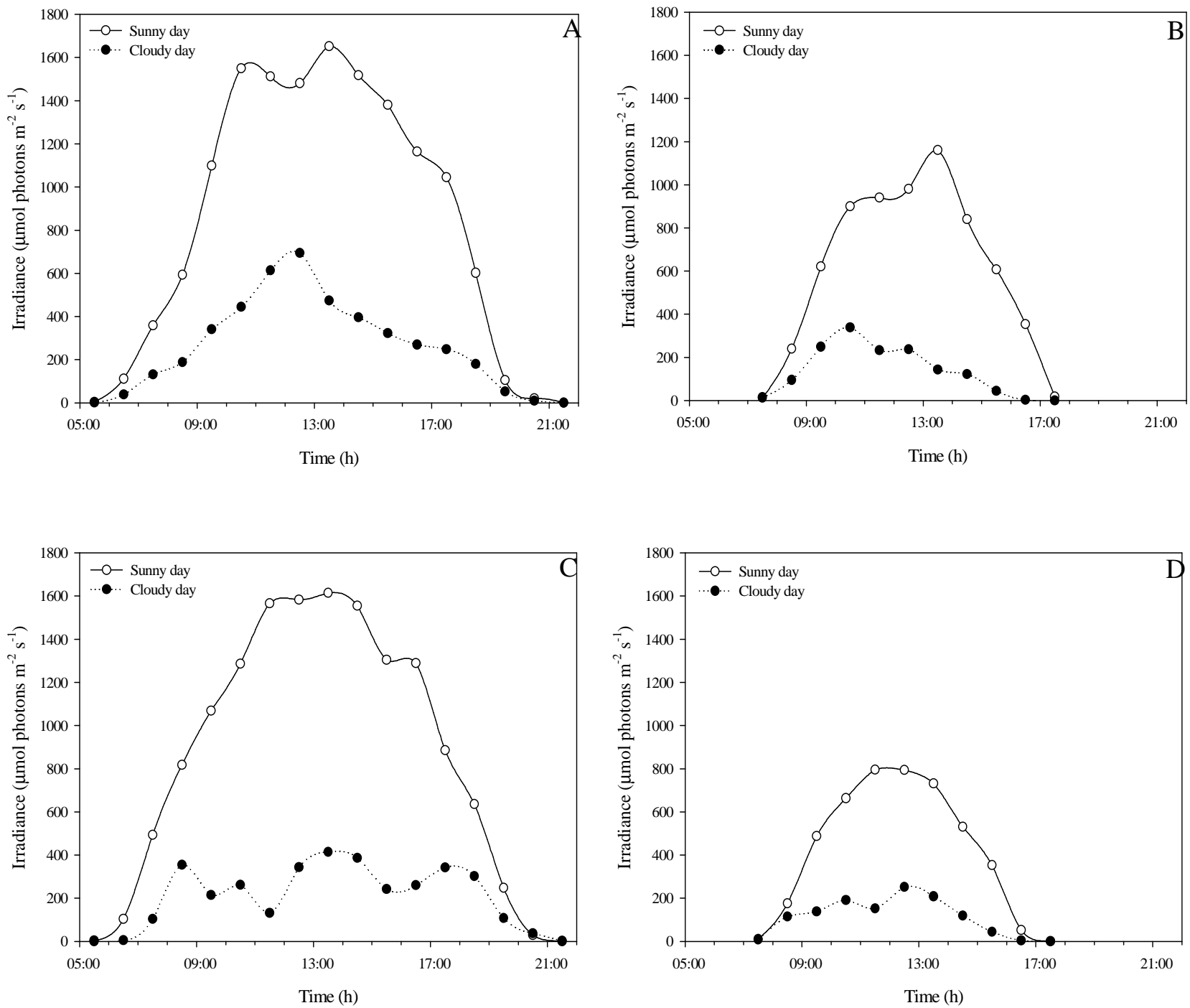

Figure 2.4. Daily field irradiance. (A) Kau Bay during summer on sunny and cloudy days. (B) Kau Bay during winter on sunny and cloudy days $(\boldsymbol{C})$ Pauatahanui Inlet during summer on sunny and cloudy days. (D) Pauatahanui Inlet during winter on sunny and cloudy days; $(\mathrm{n}=2$ for each point, except $n=1$ for each point during winter at Kau Bay on a sunny day and during summer at Pauatahanui Inlet on a cloudy day). 

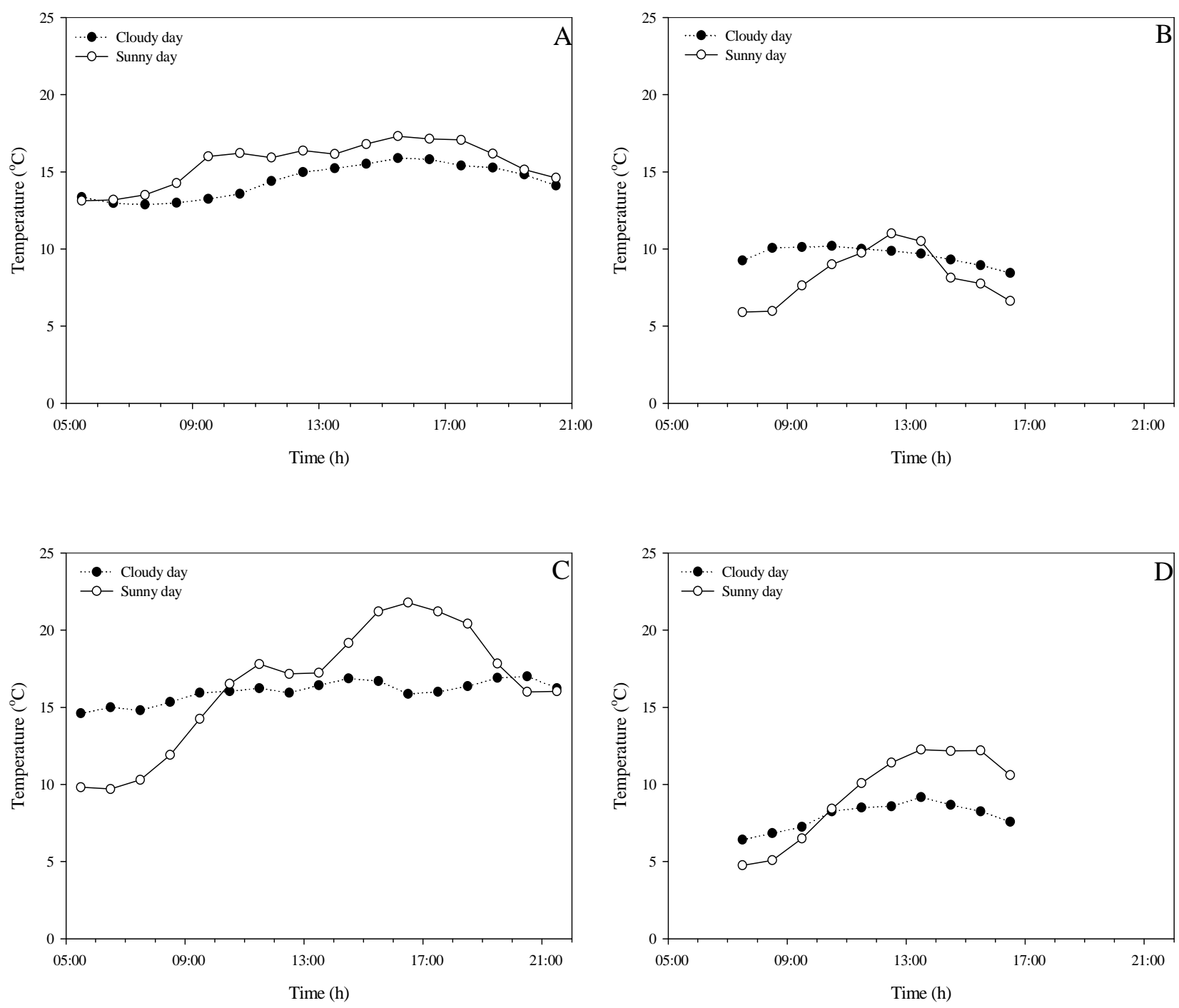

Figure 2.5. Daily field temperature. (A) Kau Bay during summer on sunny and cloudy days. (B) Kau Bay during winter on sunny and cloudy days. (C) Pauatahanui Inlet during summer on sunny and cloudy days. $(\boldsymbol{D})$ Pauatahanui Inlet during winter on sunny and cloudy days; ( $\mathrm{n}=2$ for each point, except $\mathrm{n}=1$ for each point during winter at Kau Bay on a sunny day and during summer at Pauatahanui Inlet on a cloudy day).

Table 2.3. Averaged daily temperatures for Kau Bay and Pauatahanui Inlet during summer and winter on sunny and cloudy days.

\begin{tabular}{l|cccc}
\hline & \multicolumn{2}{|c}{ Kau Bay } & \multicolumn{2}{c}{ Pauatahanui Inlet } \\
& Summer & Winter & Summer & Winter \\
Sunny day & $15.5^{\circ} \mathrm{C}$ & $9.8^{\circ} \mathrm{C}$ & $16.5^{\circ} \mathrm{C}$ & $9.3^{\circ} \mathrm{C}$ \\
Cloudy day & $12.5^{\circ} \mathrm{C}$ & $9.2^{\circ} \mathrm{C}$ & $15.7^{\circ} \mathrm{C}$ & $8.4^{\circ} \mathrm{C}$ \\
\hline
\end{tabular}




\subsubsection{Algal and symbiosis characteristics}

Algal and symbiosis biomass characteristics for Anthopleura aureoradiata are shown in Tables $2.4-2.5$. Two sample T-Tests between treatments are shown in Appendix B, Table 5.1.

\subsubsection{What is the affect of season on the algal density of A. aureoradiata?}

At Pauatahanui Inlet on a sunny day, the algal density was 2.6 times greater during summer than winter $\left(\mathrm{T}_{10}=8.92, \mathrm{p}<0.001\right)$ and on a cloudy day the algal density was 1.7 times greater in summer than winter $\left(\mathrm{T}_{9}=4.37, \mathrm{p}=0.002\right)$. Seasonal differences in the algal density resulted in an increase of the algal to total symbiosis biomass ratio from winter to summer. This difference was further exacerbated by a decrease of $1.5-2.1$ times in animal protein from winter to summer. Algal to total symbiosis protein ratios were greatest during summer at Kau Bay on a sunny day (69\%) and lowest during winter at Pauatahanui Inlet on a sunny day (32\%). 
Table 2.4. Anthopleura aureoradiata algal and symbiosis biomass-characteristics for summer: $\mathrm{n}=5$ except: Kau Bay (cloudy day) $\mathrm{n}=6$, Pauatahanui Inlet (sunny day) $\mathrm{n}=7$ and algal cell diameter $n=100$; Values are means \pm 1 SE.

\begin{tabular}{|c|c|c|c|c|}
\hline Characteristic & $\begin{array}{c}\text { Kau Bay } \\
\text { (Cloudy day) }\end{array}$ & $\begin{array}{c}\text { Kau Bay } \\
\text { (Sunny day) }\end{array}$ & $\begin{array}{c}\text { Pauatahanui Inlet } \\
\text { (Cloudy day) }\end{array}$ & $\begin{array}{c}\text { Pauatahanui Inlet } \\
\text { (Sunny day) }\end{array}$ \\
\hline $\begin{array}{l}\text { Algal cell diameter } \\
\qquad(\mu \mathrm{m})\end{array}$ & $10.48 \pm 0.11$ & $11.46 \pm 0.1$ & $10.25 \pm 0.09$ & $9.73 \pm 0.09$ \\
\hline $\begin{array}{l}\text { Algal cell volume } \\
\qquad\left(\mu \mathrm{m}^{3}\right)\end{array}$ & 601.51 & 788.16 & 563.57 & 481.33 \\
\hline $\begin{array}{l}\text { Derived algal cell carbon } \\
\qquad\left(\mathrm{pg} \mathrm{C} \text { cell }^{-1}\right)\end{array}$ & 88.48 & 111.81 & 83.62 & 72.95 \\
\hline $\begin{array}{l}\text { Derived algal cell protein } \\
\quad\left(\text { pg protein cell }{ }^{-1}\right)\end{array}$ & 90.65 & 114.56 & 85.68 & 74.74 \\
\hline $\begin{array}{l}\mathrm{N} \text { content per cell } \\
(\mathrm{pg})\end{array}$ & 14.5 & 18.33 & 13.71 & 11.96 \\
\hline $\begin{array}{l}\text { Total no. of algae per anemone } \\
\left(\times 10^{6}\right)\end{array}$ & $4.7 \pm 0.57$ & $7.41 \pm 0.74$ & $5.22 \pm 0.27$ & $6.5 \pm 0.28$ \\
\hline $\begin{array}{l}\text { Total animal protein } \\
(\mu \mathrm{g})\end{array}$ & $307.64 \pm 33.12$ & $379.96 \pm 65.67$ & $316.06 \pm 21.25$ & $423.87 \pm 20.23$ \\
\hline $\begin{array}{c}\text { Algal density } \\
\left(\text { algae } \mu \mathrm{g}^{-1} \text { protein } \times 10^{3}\right)\end{array}$ & $15.76 \pm 1.7$ & $21.57 \pm 4.18$ & $16.86 \pm 1.54$ & $15.1 \pm 0.61$ \\
\hline $\begin{array}{l}\text { Total algal protein } \\
(\mathrm{mg})\end{array}$ & $1.43 \pm 0.15$ & $2.47 \pm 0.48$ & $1.44 \pm 0.13$ & $1.13 \pm 0.05$ \\
\hline Algal: Total protein ratio & $0.58 \pm 0.03$ & $0.69 \pm 0.03$ & $0.59 \pm 0.02$ & $0.53 \pm 0.01$ \\
\hline $\begin{array}{l}\left.\text { Derived algal carbon standing stock ( } \mathrm{C}^{\prime}\right) \\
\qquad\left(\mu \mathrm{g} \mathrm{C} \mu \mathrm{g}^{-1} \text { protein) }\right.\end{array}$ & $1.39 \pm 0.15$ & $2.4 \pm 0.47$ & $1.41 \pm 0.13$ & $1.13 \pm 0.4$ \\
\hline
\end{tabular}


Table 2.5. Anthopleura aureoradiata algal and symbiosis biomass-characteristics for winter: $n=7$ except: Pauatahanui Inlet (cloudy day) $n=6$, Pauatahanui Inlet (sunny day) $\mathrm{n}=5$ and algal cell diameter $\mathrm{n}=100$; Values are means \pm 1 SE.

\begin{tabular}{|c|c|c|c|c|}
\hline Characteristic & $\begin{array}{c}\text { Kau Bay } \\
\text { (Cloudy day) }\end{array}$ & $\begin{array}{c}\text { Kau Bay } \\
\text { (Sunny day) }\end{array}$ & $\begin{array}{l}\text { Pauatahanui Inlet } \\
\text { (Cloudy day) }\end{array}$ & $\begin{array}{l}\text { Pauatahanui Inlet } \\
\text { (Sunny day) }\end{array}$ \\
\hline $\begin{array}{l}\text { Algal cell diameter } \\
\qquad(\mu \mathrm{m})\end{array}$ & $10.93 \pm 0.11$ & $11.09 \pm 0.11$ & $10.5 \pm 0.1$ & $10.18 \pm 0.07$ \\
\hline $\begin{array}{l}\text { Algal cell volume } \\
\qquad\left(\mu \mathrm{m}^{3}\right)\end{array}$ & 682.41 & 713.31 & 605.84 & 551.29 \\
\hline $\begin{array}{l}\text { Derived algal cell carbon } \\
\qquad\left(\mathrm{pg} C \text { cell }^{-1}\right)\end{array}$ & 98.7 & 102.55 & 89.02 & 82.04 \\
\hline $\begin{array}{l}\text { Derived algal cell protein } \\
\quad\left(\mathrm{pg} \text { protein cell }{ }^{-1}\right)\end{array}$ & 101.12 & 105.07 & 91.21 & 84.06 \\
\hline $\begin{array}{l}\mathrm{N} \text { content per cell } \\
(\mathrm{pg})\end{array}$ & 16.18 & 16.81 & 14.59 & 13.45 \\
\hline Total no. of algae per anemone $\times 10^{6}$ & $8.28 \pm 0.6$ & $6.69 \pm 0.63$ & $6.07 \pm 0.95$ & $4.9 \pm 0.49$ \\
\hline $\begin{array}{l}\text { Total animal protein } \\
\qquad(\mu \mathrm{g})\end{array}$ & $475.66 \pm 53.2$ & $549.73 \pm 74.16$ & $637.89 \pm 97.66$ & $877.01 \pm 100.94$ \\
\hline $\begin{array}{l}\text { Algal density } \\
\text { (algae } \mu \mathrm{g}^{-1} \text { protein } \times 10^{3} \text { ) }\end{array}$ & $18.9 \pm 2.51$ & $13.09 \pm 1.52$ & $9.66 \pm 0.8$ & $5.71 \pm 0.84$ \\
\hline $\begin{array}{l}\text { Total algal protein } \\
(\mathrm{mg})\end{array}$ & $1.91 \pm 0.25$ & $1.38 \pm 0.16$ & $0.88 \pm 0.07$ & $0.48 \pm 0.07$ \\
\hline Algal: Total protein ratio & $0.64 \pm 0.03$ & $0.57 \pm 0.03$ & $0.47 \pm 0.02$ & $0.32 \pm 0.03$ \\
\hline $\begin{array}{l}\left.\text { Derived algal carbon standing stock ( } \mathrm{C}^{\prime}\right) \\
\left(\mu \mathrm{g} \mathrm{C} \mu \mathrm{g}^{-1} \text { protein }\right)\end{array}$ & $1.87 \pm 0.25$ & $1.34 \pm 0.16$ & $0.86 \pm 0.07$ & $0.47 \pm 0.07$ \\
\hline
\end{tabular}




\subsubsection{Mitotic index}

The mitotic index (MI) over a diel period during summer and winter at Kau Bay and Pauatahanui Inlet on sunny and cloudy days is shown in Fig. 2.6. Cell division was determined as asynchronous across habitat, season and cloud cover. A one-way ANOVA determined that there was no significant difference amongst cell division rates at Kau Bay during summer (Fig. 2.6A) across the course of a cloudy $\left(F_{7,72}=0.951, p=0.473\right)$ and sunny day $\left(\mathrm{F}_{7,72}=1.339, \mathrm{p}=0.245\right)$, and similarly at Pauatahanui Inlet during summer (Fig. 2.6C) across the course of a cloudy $\left(\mathrm{F}_{7,72}=0.686, \mathrm{p}=0.683\right)$ and sunny day $\left(\mathrm{F}_{7}, 72=0.253, \mathrm{p}=0.97\right)$. Additionally, during winter, a one-way ANOVA determined that there was no significant difference in the MI over a diel period at Kau Bay on a cloudy $\left(\mathrm{F}_{3,56}=0.75, \mathrm{p}=0.527\right)$ and sunny day $\left(\mathrm{F}_{3,56}=2.48, \mathrm{p}=0.07\right)$ (Fig. 2.6B) and also at Pauatahanui Inlet across the course of a cloudy $\left(\mathrm{F}_{3,56}=1.08, \mathrm{p}=0.365\right)$ and sunny day $\left(\mathrm{F}_{3,56}=2.46, \mathrm{p}=0.72\right)$ (Fig. 2.6D).

\subsubsection{What is the affect of season on the MI of algae within A. aureoradiata?}

The averaged mitotic index over a period of a day is shown in Fig. 2.7. Two Sample Ttests between treatments are shown in Appendix B, Table 5.2. The MI was higher during winter than summer by 2.1 times at Kau Bay $\left(T_{138}=5.14, p<0.001\right)$, and by 1.3 times at Pauatahanui Inlet $\left(\mathrm{T}_{138}=5.14, \mathrm{p}<0.001\right)$ on sunny days. 

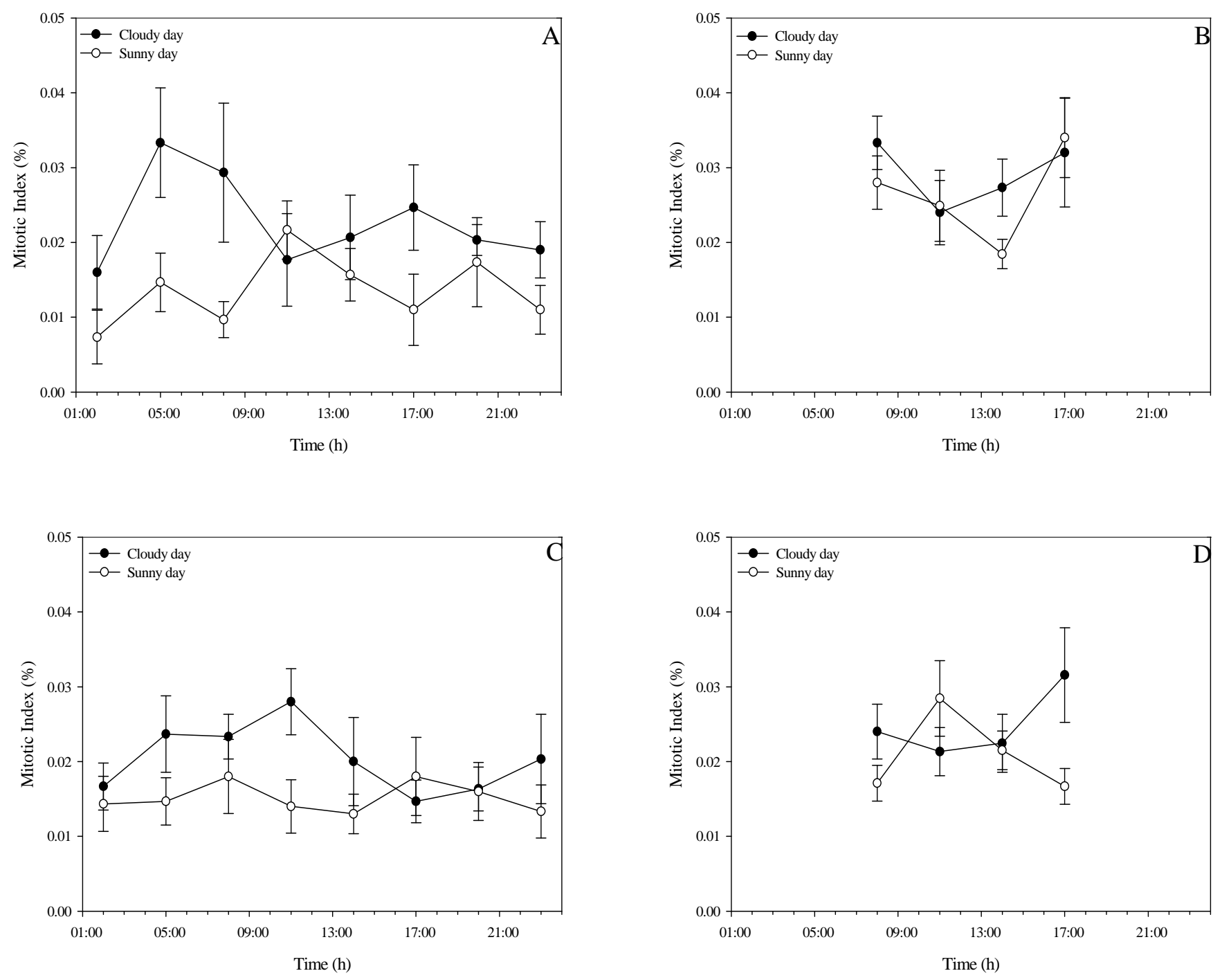

Figure 2.6. Mitotic index for Anthopleura aureoradiata. (A) Kau Bay during summer on a cloudy ( $\mathrm{n}=10$ for each point) and sunny day ( $\mathrm{n}=10$ for each point). (B) Kau Bay during winter on a cloudy ( $\mathrm{n}=15$ for each point) and sunny day ( $\mathrm{n}=15$ for each point). $(\boldsymbol{C})$ Pauatahanui Inlet during summer on a cloudy ( $\mathrm{n}=10$ for each point) and sunny $(\mathrm{n}=10$ for each point) day. (D) Pauatahanui Inlet during winter on a cloudy ( $\mathrm{n}=15$ for each point) and sunny ( $\mathrm{n}=15$ for each point) day; values are means \pm 1 SE. 


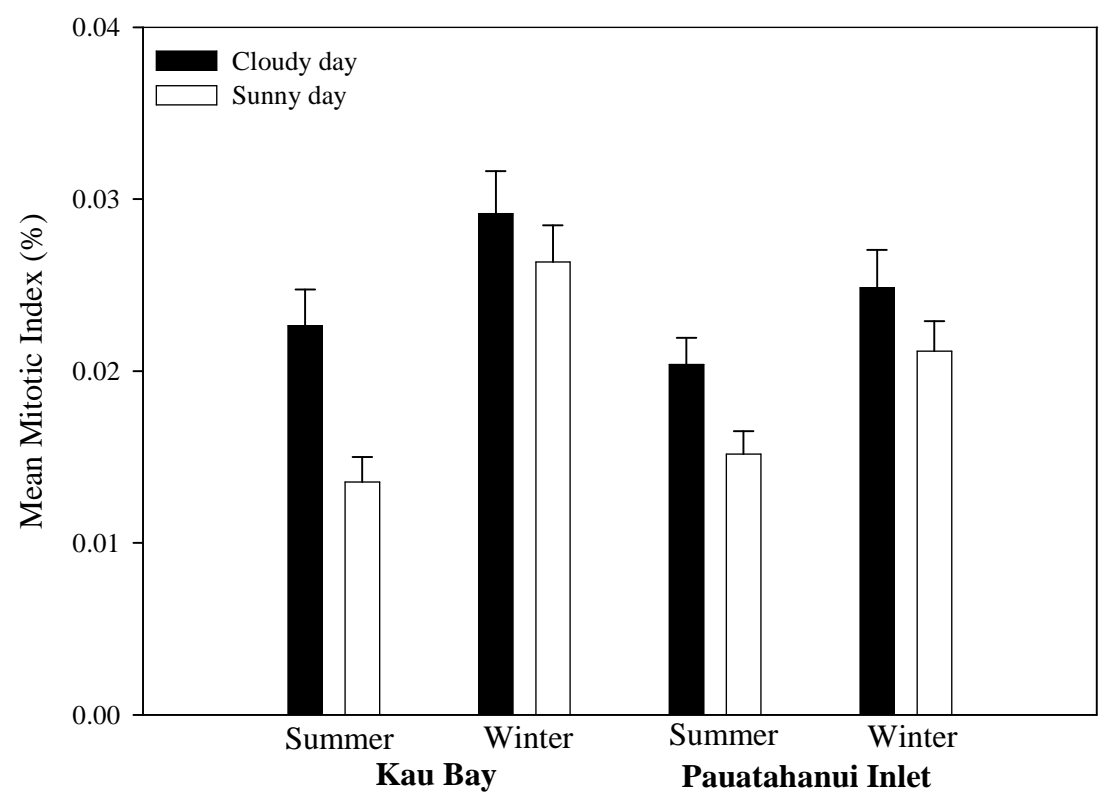

Figure 2.7. Percentage of algal cells undergoing mitosis in Anthopluera aureoradiata from Kau Bay and Pauatahanui Inlet during summer and winter on cloudy and sunny days ( $\mathrm{n}=15$ for Kau Bay and Pauatahanui Inlet during winter on cloudy and sunny days; $\mathrm{n}=10$ for Kau Bay and Pauatahanui Inlet during summer on cloudy and sunny days); values are means $\pm 1 \mathrm{SE}$.

\subsubsection{Photosynthesis vs. irradiance}

Plots of gross photosynthesis versus irradiance (P-I curves) for A aureoradiata collected from Kau Bay and Pauatahanui Inlet during summer and winter on sunny and cloudy days are shown (Fig. 2.8). Two Sample T-tests between treatments are shown for all photosynthetic parameters in Appendix B, Tables 5.3 - 5.8. For clarification, only significant differences are described here.

\subsubsection{What is the effect of season and cloud cover on the photophysiology and respiration of $\mathrm{A}$. aureoradiata?}

The initial slope of the P-I curve ( $\alpha$ ) (Fig. 2.9A), was 5.2 times greater during summer on a sunny day at Pauatahanui Inlet than in winter $\left(\mathrm{T}_{10}=5.33, \mathrm{p}<0.001\right)$. Similarly, respiration rates (Fig 2.9B) were also greater during summer than in winter at 
Pauatahanui Inlet but on both cloudy $\left(\mathrm{T}_{9}=10.01, \mathrm{P}<0.001\right)$ and sunny days $\left(\mathrm{T}_{10}=15.4\right.$, $\mathrm{p}<0.001)$. The interaction between $\alpha$ and respiration during summer and winter resulted in no seasonal differences in the compensation irradiance $\left(I_{c}\right)$ (Fig. 2.9C), furthermore the 95\% saturation irradiance $\left(\mathrm{I}_{\mathrm{k}}\right)$ (Fig. 2.9D) also displayed no change with season. Yet, the rate of cell specific $\mathrm{P}_{\max }$ gross (Fig. 2.9E) was 1.6 times greater during summer than in winter at Kau Bay on a sunny day $\left(\mathrm{T}_{10}=4.61, \mathrm{p}<0.001\right)$, but the greater zooxanthellar density at this time of year meant that maximum photosynthesis ( $\mathrm{P}_{\max }$ gross) (Fig. 2.9F) on sunny days was 2.7 times greater at Kau Bay during summer than in winter $\left(\mathrm{T}_{10}=\right.$ $4.99, \mathrm{p}<0.001$ ), and similarly was 4 times greater at Pauatahanui Inlet in summer than in winter on sunny days $\left(\mathrm{T}_{10}=8.11, \mathrm{p}<0.001\right)$. A further seasonal difference was observed between seasons at Pauatahanui Inlet when during summer on a cloudy day, the rate of $\mathrm{P}_{\max }$ gross was 2.6 times greater than winter on a cloudy day $\left(\mathrm{T}_{9}=10.9, \mathrm{p}<0.001\right)$.

The effect within season of cloud cover was limited, resulting in a single difference in cell specific $\mathrm{P}_{\max }$ gross, when the rate during summer at Kau Bay was 1.5 times greater on a sunny day than on a cloudy day $\left(\mathrm{T}_{9}=4.38, \mathrm{p}=0.002\right)$.

\section{What is the affect of habitat on the photophysiology and respiration of A. aureoradiata?}

The rate of $\alpha$ was higher at Kau Bay than Pauatahanui Inlet during winter by 2.1 times on a cloudy day $\left(\mathrm{T}_{11}=4.16, \mathrm{p}=0.002\right)$ and by 2.9 times on a sunny day $\left(\mathrm{T}_{10}=4.73, \mathrm{p}<\right.$ 0.001). Respiration was also higher at Kau Bay than Pauatahanui Inlet during winter on both cloudy $\left(\mathrm{T}_{11}=4.86, \mathrm{p}<0.001\right)$ and sunny days $\left(\mathrm{T}_{10}=5.22, \mathrm{p}<0.001\right)$. In contrast $\mathrm{I}_{\mathrm{c}}$ was 1.8 times greater at Pauatahanui inlet during summer on a cloudy day than Kau Bay. $\mathrm{I}_{\mathrm{k}}$ and cell specific $\mathrm{P}_{\max }$ gross displayed no difference due to habitat however, $\mathrm{P}_{\max }$ gross was 2.2 times greater at Kau Bay than Pauatahanui Inlet during winter on both a sunny $\left(\mathrm{T}_{10}=8.4, \mathrm{p}<0.001\right)$ and cloudy day $\left(\mathrm{T}_{11}=6, \mathrm{p}<0.001\right)$. 

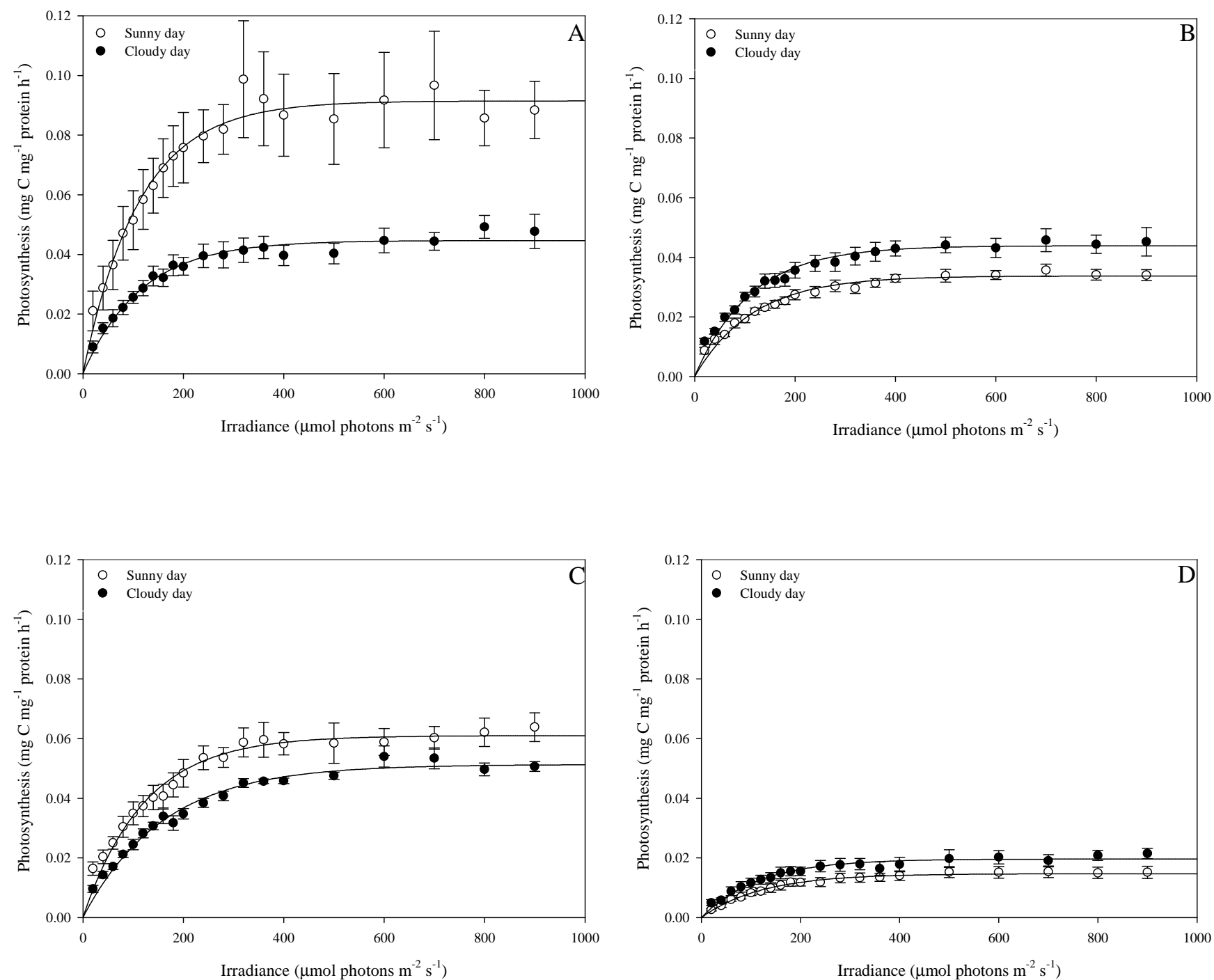

Figure 2.8. Photosynthesis vs. irradiance curves for Anthopleura aureoradiata. (A) Kau Bay during summer on sunny $(\mathrm{n}=5)$ and cloudy $(\mathrm{n}=6)$ days. $(\boldsymbol{B})$ Kau Bay during winter on sunny $(\mathrm{n}=7)$ and cloudy $(\mathrm{n}=7)$ days. $(\boldsymbol{C})$ Pauatahanui Inlet during summer on sunny (n $=7)$ and cloudy days $(\mathrm{n}=5)$. (D) Pauatahanui Inlet during winter on sunny $(\mathrm{n}=5)$ and cloudy $(n=5)$ days; values are mean $\pm 1 \mathrm{SE}$ 

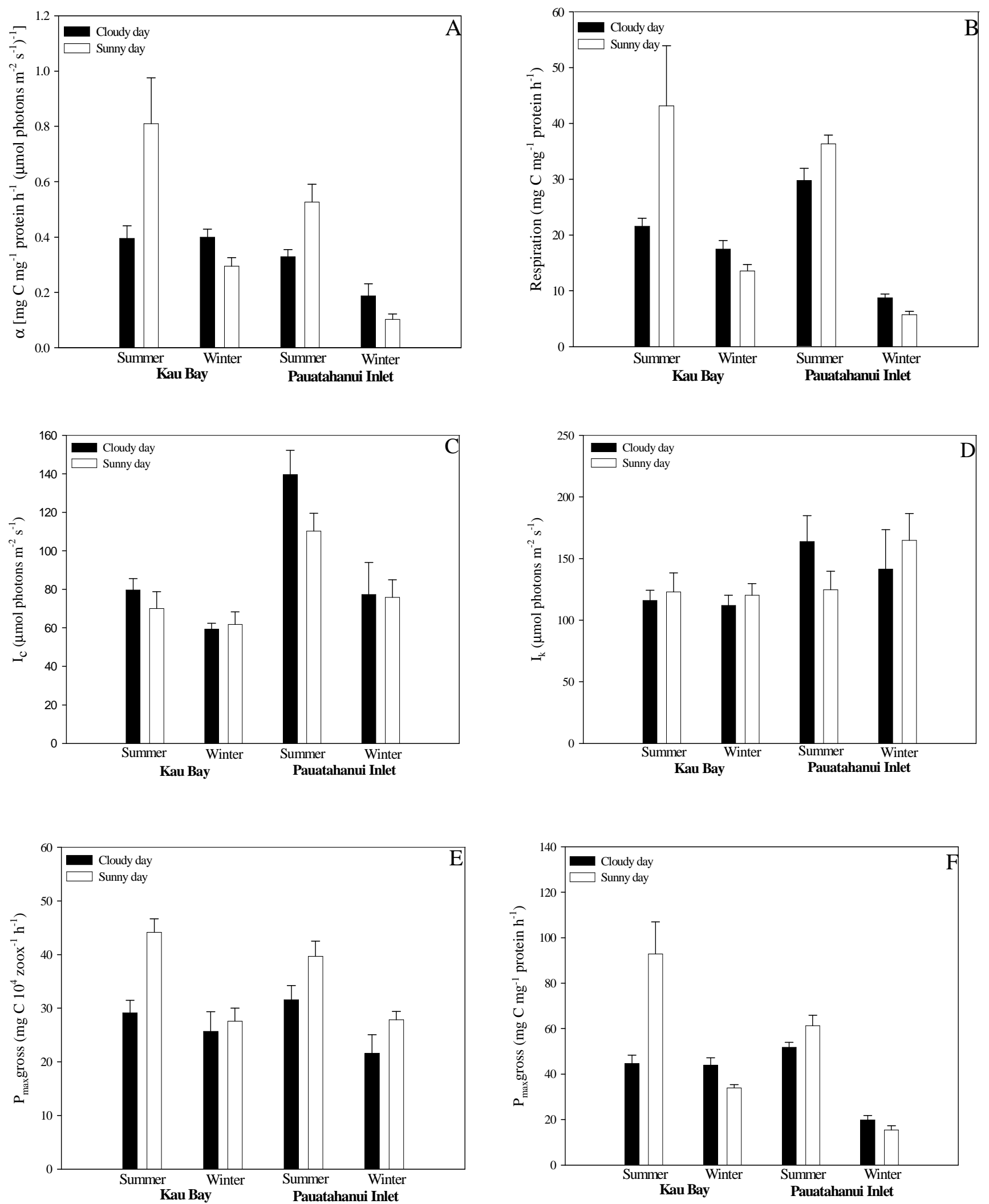

Figure 2.9. Photosynthesis - irradiance parameters for Anthoplerua aureoradiata at Kau Bay and Pauatahanui Inlet during summer and winter on overcast and clear sky days. (A) initial slope of $\mathrm{P}$ - I curve $(\alpha)$, $(\boldsymbol{B})$ dark respiration rate of intact symbiosis, $(\boldsymbol{C})$ compensation irradiance $\left(\mathrm{I}_{\mathrm{c}}\right),(\boldsymbol{D})$ 95\% saturation irradiance $\left(\mathrm{I}_{\mathrm{k}}\right),(\boldsymbol{E})$ cell specific $\mathrm{P}_{\max }$ gross, $(\boldsymbol{F})$ maximum rate of photosynthesis ( $\mathrm{P}_{\max }$ gross). $(\mathrm{n}=5$ for Kau Bay, summer, sunny / Pauatahanui Inlet, summer, sunny / Pauatahanui Inlet, winter, sunny and cloudy) $(\mathrm{n}=6$ for Kau Bay, summer, cloudy) ( $\mathrm{n}=7$ for Kau Bay, winter, sunny and cloudy / Pauatahanui Inlet, summer, sunny); values are means $\pm 1 \mathrm{SE}$. 


\subsubsection{Rates of respiration, net photosynthesis, and carbon translocation}

Biomass specific rates of the host's respiration and estimates of the potential contribution of translocated carbon to its daily respiratory carbon requirements (CZAR) are given in Table 2.6. Rates of $\mathrm{P}_{\mathrm{z}}$ net were typically between $4-5$ times greater during summer than in winter; however, an extreme difference was observed at Kau Bay on cloudy days when $\mathrm{P}_{\mathrm{z}}$ net was 51 times greater during summer than in winter. Carbon translocation rates were 1.2 - 1.9 times greater during summer, than in winter on a sunny day, as a result of increasing photosynthetic carbon availability. In contrast, low light during winter especially, on cloudy days, led to translocation rates of zero at both Kau Bay and Pauatahanui Inlet. 
Table 2.6. Parameters used in the estimation of CZAR for Anthopleura aureoradiata from Kau Bay and Pauatahanui Inlet during summer and winter on sunny and cloudy days $\left(\mu=\right.$ cell specific growth rate; $\mathrm{P}_{\mathrm{z}}=$ predicted net photosynthesis by zooxanthellae; $\mu_{\mathrm{c}}=$ carbon specific growth rate; $\mathrm{T}=$ percentage of net fixed carbon translocated to host; $\mathrm{R}_{\mathrm{a}}=$ predicted animal respiration per day).

\begin{tabular}{|c|c|c|c|c|c|c|c|c|}
\hline \multirow[t]{2}{*}{ Parameter } & \multicolumn{2}{|c|}{$\begin{array}{l}\text { Kau Bay } \\
\text { (Sunny) }\end{array}$} & \multicolumn{2}{|c|}{$\begin{array}{l}\text { Kau Bay } \\
\text { (Cloudy) }\end{array}$} & \multicolumn{2}{|c|}{$\begin{array}{c}\text { Pauatahanui Inlet } \\
\text { (Sunny) }\end{array}$} & \multicolumn{2}{|c|}{$\begin{array}{c}\text { Pauatahanui Inlet } \\
\text { (Cloudy) }\end{array}$} \\
\hline & Summer & Winter & Summer & Winter & Summer & Winter & Summer & Winter \\
\hline$\mu\left(d^{-1}\right)$ & 0.0293 & 0.0566 & 0.0488 & 0.0628 & 0.033 & 0.0458 & 0.044 & 0.0535 \\
\hline 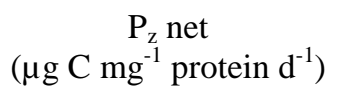 & 557.66 & 139.41 & 347.4 & 6.78 & 402.35 & 83.28 & 128.62 & 29.73 \\
\hline$\mu_{c}\left(d^{-1}\right)$ & 0.2312 & 0.1039 & 0.2492 & 0.0036 & 0.3548 & 0.1772 & 0.0912 & 0.0346 \\
\hline $\mathrm{T}(\%)$ & 87.35 & 45.48 & 80.43 & 0 & 90.7 & 74.17 & 51.76 & 0 \\
\hline$\underset{\left(\mu \mathrm{g} \mathrm{C} \mathrm{mg}^{-1} \text { protein } \mathrm{d}^{-1}\right)}{\mathrm{R}_{\mathrm{a}}}$ & 320.88 & 139.68 & 216 & 150.72 & 409.68 & 94.08 & 293.04 & 111.36 \\
\hline
\end{tabular}




\subsubsection{Daily CZAR}

The daily CZAR was greatest at Kau Bay during summer on a sunny day (Fig. 2.10), where the algae completely satisfied the energy requirements of the animal host, with a CZAR of 151\%; on an overcast day during summer at Kau Bay the CZAR also satisfied the animal's energy requirements (CZAR 129\%). On a sunny, winter day at Kau Bay, the CZAR reached $45 \%$ of the animal's daily energy requirements, but on a cloudy day the CZAR was zero. The CZAR for A. aureoradiata from Pauatahanui Inlet during summer on a sunny (89\%) and cloudy day $(65 \%)$ and winter on a sunny (22\%) and cloudy day (0\%) failed to reach $100 \%$, thus not completely satisfying the animals daily respiratory requirements.

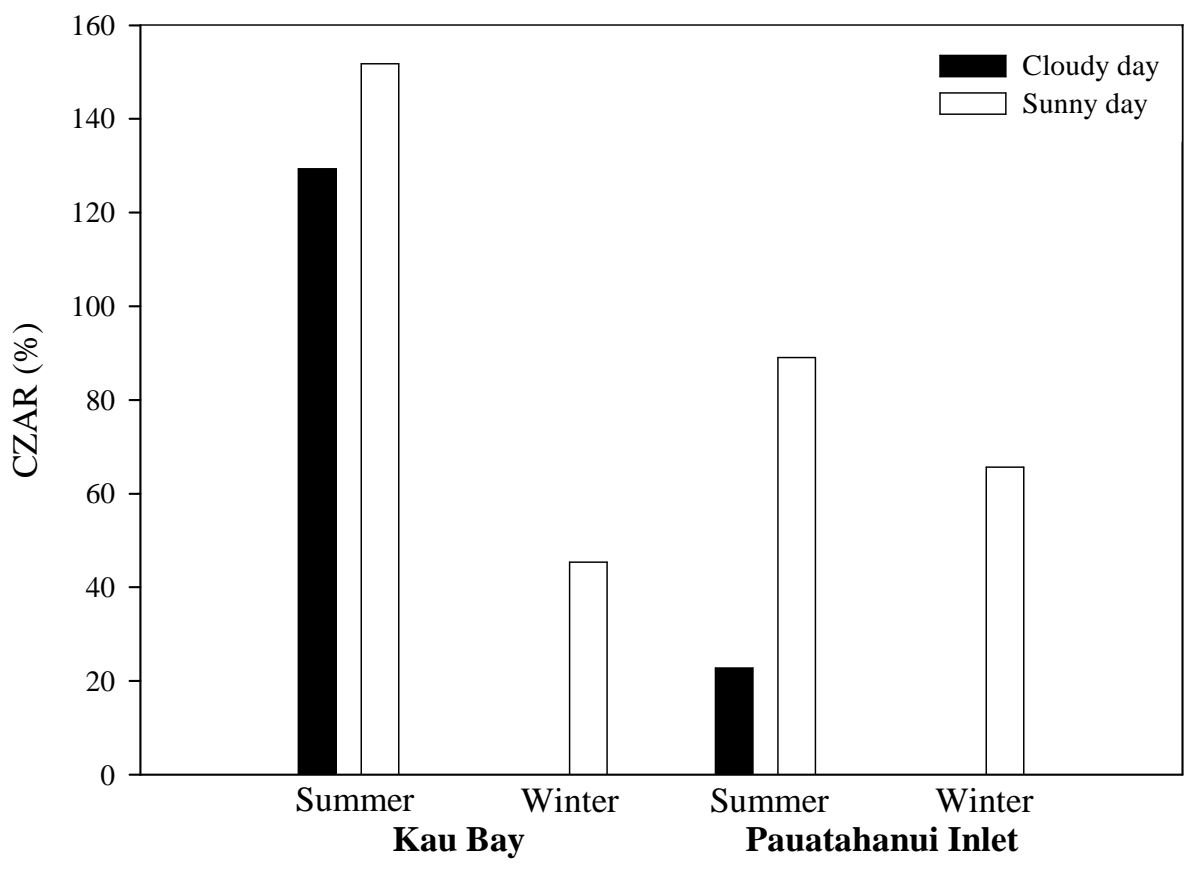

Figure 2.10. Daily CZAR for Anthopleura aureoradiata from Kau Bay and Pauatahanui Inlet during summer and winter on a cloudy and sunny day; no bar represents a CZAR of zero. All values calculated from averaged parameters $(n=4)$, hence no error bars are shown. 


\subsection{Discussion}

The effect of season resulted in the algal density being greater during summer than winter, while the MI was asynchronous and higher during winter than summer at Kau Bay and Pauatahanui Inlet on sunny days. Seasonal differences in the photophysiology and respiration of Anthopleura aureoradiata were greater during summer than winter, while cloud cover resulted in a higher rate of cell specific $\mathrm{P}_{\max }$ gross on a sunny day than a cloudy day within summer at Kau Bay. The effect of habitat resulted in differences in the photophysiology and respiration to be greater at Kau Bay than Pauatahanui Inlet with the exception of $I_{c}$ which was higher at Pauatahanui Inlet. The contribution of the zooxanthellae to the animal host's daily respiratory carbon budget (CZAR) was calculated $>100 \%$ for A. aureoradiata from Kau Bay during summer and thus the host may not rely on heterotropic feeding to provide energy for its metabolic activities. In contrast, the highest CZAR value at Pauatahanui Inlet was measured as $89 \%$ during the summer on a sunny day while CZAR values of zero were measured from Kau Bay and Pauatahanui Inlet during the winter on cloudy days.

\subsubsection{Algal cell size and density}

\subsubsection{Algal cell size}

Under high light conditions zooxanthellar size has been shown to vary from $6-9 \mu \mathrm{m}$ (Titlyanov and Titlyanova 2002). Zooxanthella size in A. aureoradiata $(9.73-11.46$ $\mu \mathrm{m}$ ) is similar to that seen in corals acclimated to low light environments (Wilkerson et al. 1988; Titlyanov et al. 2001). Titlyanov et al. (2001) suggest two reasons for the 
acclimation to large zooxanthellae in low light environments. First, the reduced light intensity leads to a significant decrease in the frequency of division and degradation of zooxanthellae, thus increasing the average age of the zooxanthellae in the colony and resulting in an accumulation of old large cells. Second, if a cnidarian contains a mixture of genetically different types of zooxanthellae (Rowan 1998) differing in sizes, a decrease in light intensity can lead to an increase or retention of one type of zooxanthellae with large cells; there is currently no evidence for mixed symbiont populations in A. aureoradiata.

\subsubsection{Algal densities}

Algal densities reported from this study show a trend of increasing from winter to summer. Studies examining seasonal algal densities have not reported consistent results. Some researchers have found algal densities to be higher in winter (Stimson 1997; Brown et al. 1999; Fagoonee et al. 1999; Fitt et al. 2000), summer (Verde and McCloskey 2007) or consistent throughout the year (Dykens and Shick 1984; Porter et al. 1984; Jones and Yellowlees 1997; Verde and McCloskey 1998). Many studies showing an increase in algal density during winter were conducted with tropical cnidarian species (Stimson 1997; Brown et al. 1999; Fagoonee et al. 1999; Fitt et al. 2000) that suffer from bleaching during the summer months and hence have lower algal densities than during winter; temperate associations are not stressed in this manner during summer (Verde and McCloskey 2001).

The effect of seasonality on algal density in this study may occur through changes in temperature or PAR light or both. Temperature has been suggested to have a greater influence on algal density than does light intensity in both tropical and temperate associations (Hoegh-Guldberg and Smith 1989a; Saunders and Muller-Parker 
1997). This is because increases in water temperature can cause algae to rapidly be expelled from the host, resulting in a reduced number of algae within the association (Lesser et al. 1990; Fitt et al. 1993; Berkelmans and Willis 1999; Buck et al. 2002). Alternatively, decreased temperature has also been shown to cause reductions in the algal density in a number of cnidarian species (Coles and Jokiel 1977; Steen and Muscatine 1987; Muscatine et al. 1991; Saxby et al. 2003), though in the temperate Anthopleura elegantissima temperature has no effect (Engebretson and Muller-Parker 1999; Verde and McCloskey 2001).

The effect of light intensity on algal density is varied. Titlyanov et al. (2001) documented an $80 \%$ increase in algal density over 40 days within the coral Stylophora pistillata when exposed to $30 \%$ PAR compared with 95\%. Furthermore, the algal density doubled when the light intensity was further reduced to $8 \%$ PAR compared with 30\%. Saunders and Muller-Parker (1997) found that low light caused a significant increase in the density of zooxanthellae within the temperate A. elegantissima over 25 days. Alternatively, Fitt and Cook (2001) reported that shaded colonies of the tropical hydroid Myrionema amboinense contained half the algal density of high light colonies after a period of 4 weeks. Many studies have reported no change in algal density with increased light availability in tropical (Falkowski and Dubinsky 1981; Lesser et al. 1990) and temperate species (Harland and Davies 1994; McCloskey et al. 1996; Verde and McCloskey 2002).

Seasonal fluctuations in algal densities are thought to impact on the host tissue biomass. Fitt et al. (2000) documented that decreased densities of symbionts during the warmer seasons cause decreases in animal protein biomass, while increasing symbiont densities during the cooler seasons were thought to drive increases in animal protein. A possible explanation for the seasonal changes is that the combined effects of elevated 
seawater temperature and irradiance result in higher respiration rates of both host and zooxanthellae during the warmer seasons. This can result in lower net photosynthesis and translocation rates, which are less likely to meet the higher metabolic energy demand at higher temperatures and so increase reliance on the catabolism of host protein. In contrast to Fitt et al. (2000), in this study, algal density was highest during summer compared with winter. However, animal protein was lowest during summer and highest during winter. As the algal density was standardised to animal protein, the seasonal variations in algal density may in part be due to this change in anemone protein, in addition to the regulation of symbionts in response to changes in environmental conditions (Verde and McCloskey 2001).

\subsubsection{Algal cell growth}

Daily cell division rates of in hospite algae undergoing mitosis are known to vary between 0.33 - 4.69\% for temperate (Wilkerson et al. 1983, Davy et al. 1996, McCloskey et al. 1996, Verde and McCloskey 1996b, Verde and McCloskey 2007) and $0.2-12.3 \%$ for tropical species (e.g. Wilkerson et al. 1983, Muller-Parker 1985; 1987, Wilkerson et al. 1988). The average daily MI recorded in this study $(1.4-2.9 \%)$ from zooxanthellae within A. aureoradiata is well within this range for temperate and tropical species.

Rates of cell division may be correlated with irradiance, temperature and nutrient availability. Increased light intensities increase the photosynthetic rate leading to greater amounts of photosynthate available for producing new cells (Verde and McCloskey 2002). Additionally, increased temperatures have been shown to stimulate cell division as a result of a higher metabolism (Suharsono and Brown 1992); colder 
temperatures may suppress algal metabolism and growth (Verde and McCloskey 2007). Yet, nutrients are likely the most important limiting factor and may explain the increased division rate in winter, when nutrient concentrations in seawater are typically highest. The addition of nutrients, such as nitrogen and phosphorus stimulates cell division whilst a reduction in the abundance of heterotrophic food sources leads to a decrease in the MI (Cook et al. 1988, McAuley and Cook 1994, Smith and Muscatine 1999, Fitt and Cook 2001). Similarly, high nutrient concentrations in deeper waters may have also led to five out of eight corals sampled by Wilkerson et al. (1988) to have a higher MI value compared with those in shallower waters, and the high MI reported for Mastigias sp. (10.8\%) (Wilkerson et al. 1983).

Cell division over a diel cycle was determined to be asynchronous and independent of season, cloud cover and habitat. Asynchronous division has been reported in other associations (Steen and Muscatine 1984, Muller-Parker 1985, Wilkerson et al. 1988, Verde and McCloskey 2007) and was suggested by Wilkerson et al. (1988) to be host controlled, as asynchronous division is a characteristic of growthrestricted phytoplankton populations, and the need to regulate the algal population. However, the commonness of synchronised division within various associations (Wilkerson et al. 1983; McAuley and Cook 1994; Fitt 2000) suggests this statement by Wilkerson et al. (1983) may need review (Hoegh-Guldberg and Smith 1989a) as synchronised cell division appears more common than asynchronous division (Fitt 2000). Synchronised cell division in hospite has been related to pulses of nitrogen, which are also thought to be responsible for phased division in phytoplankton populations in the field (Doyle and Poore 1974). Additionally, sampling of the MI from zooxanthellae within the tentacles, as occurred in this study, may lead to an overestimation of the MI. This is because the MI in the tentacles of some algal- 
invertebrate associations may be higher compared to the rest of the organism (Verde and McCloskey 1998). For instance, Muller-Parker (1987) reports that the algal MI from the tentacles of Aiptasia pulchella is 1.5 times greater than the MI from the anemone column. If this trend also occurs in A. aureoradiata, then this may have resulted in an underestimation of the translocation rate and CZAR, as carbon available to the host is assumed to not be used in the formation of new algal cells.

The cell specific growth rate $(\mu)$ was derived from the mitotic index to determine the amount of carbon used to synthesize new algae (Muscatine et al. 1983; Davy et al. 1996). The values of $\mu$ of $0.029-0.063 \mathrm{~d}^{-1}$ are within the accepted range for in hospite values published (0.0044 - $\left.0.25 \mathrm{~d}^{-1}\right)$ (Muller-Parker 1984; Muscatine et al. 1986; Wilkerson et al. 1988; Day 1994). The estimation of $\mu$ depends on the assumption of the duration of cytokinesis $\left(t_{\mathrm{d}}\right)$ (Wilkerson et al. 1983). $t_{\mathrm{d}}$ used in this study was originally derived as $11 \mathrm{~h}$ from the tropical scyphozoan jellyfish Mastigias sp. (Wilkerson et al. 1983). However, McCloskey et al. (1996) estimated $t_{\mathrm{d}}$ to be $28 \mathrm{~h}$ in the temperate anemone Anthopleura elegantissima, relating it to the cold waters of the Pacific North West. This suggests that in this study $t_{\mathrm{d}}$ was underestimated and that zooxanthella growth is an even smaller carbon sink than what was originally thought (Davy et al. 1996). It should be noted though, that $t_{\mathrm{d}}$ is difficult to measure directly, as zooxanthellae cannot be readily observed in situ in the natural environment indeed, no one has successfully measured algal $t_{\mathrm{d}}$ in any symbiotic cnidarian (Verde and McCloskey 1996a). 


\subsubsection{Photoacclimation}

\subsubsection{How does season and cloud cover affect the photophysiology and respiration of $\mathrm{A}$. aureoradiata?}

At temperate latitudes, seasonal differences in irradiance and sea temperature may fluctuate greatly (Brown et al. 1999). For example, at Pauatahanui Inlet on a sunny day, summertime irradiances were 2 times greater than in winter and daily averaged sea temperatures differed by $7.2^{\circ} \mathrm{C}$. Consequently, seasonal differences in light and temperature influenced the photophysiology of A. aureoradiata; these in turn likely influenced the algal density and hence photosynthetic capacity. The effects of the seasonal variation of these factors on the photophysiology of A. aureoradiata will be discussed here.

Under low irradiance, the rate of photosynthetic efficiency $(\alpha)$ is typically higher than under high irradiance (Muller-Parker 1985; Harland and Davies 1994; Kuster et al. 2000). This is as low light-acclimated organisms absorb more light due to higher levels of chlorophyll $a$ per cell (Kalituho et al. 2007). In contrast to what might be expected seasonally, the rate of $\alpha$ at Pauatahanui Inlet on a sunny day was greater during summer than winter. This is most likely due to cold winter temperatures at Pauatahanui Inlet suppressing $\alpha$ by limiting the photosynthetic activity and masking any effect of light (Saxby et al. 2003). Similarly, respiration rates are also known to be temperature dependent (Jacques et al. 1983; Raven and Geider 1988). At Pauatahanui Inlet on both sunny and cloudy days, respiration was greater during summer than winter, most likely due to a temperature difference between seasons of $7.2^{\circ} \mathrm{C}$ on sunny and $7.3^{\circ} \mathrm{C}$ on cloudy days. The interaction between $\alpha$ and respiration determines the compensation irradiance $\left(I_{c}\right)$; for example, a low $\alpha$ with a high respiration rate results in a high $I_{c}$. In this study, there was no seasonal difference in $I_{c}$ due to a high $\alpha$ and 
respiration rate during summer versus a low $\alpha$ and respiration rate during winter. A higher cell specific $\mathrm{P}_{\max }$ gross at Kau Bay on a sunny day during summer than in winter is consistent with increases in temperature and irradiance. The temperature between seasons at Kau Bay on a sunny day differed by $5.7^{\circ} \mathrm{C}$, perhaps leading to the increased rate of cell specific $\mathrm{P}_{\max }$ gross. Acclimation to higher summertime irradiance may also contribute to the higher cell specific $\mathrm{P}_{\max }$ gross during summer than in winter, however the effect of habitat on A. aureoradiata at Kau Bay may limit the capacity for this and is discussed in the next section. Seasonal differences in total maximum photosynthesis ( $\mathrm{P}_{\max }$ gross) are likely correlated with algal density or cell specific $\mathrm{P}_{\max }$ gross. For example, at Kau Bay on a sunny day, $\mathrm{P}_{\max }$ gross was greater during summer than winter which was consistent with a difference in the rate of cell specific $\mathrm{P}_{\max }$ gross but not algal density. In contrast, Pauatahanui Inlet on a sunny day, $\mathrm{P}_{\max }$ gross was also greater during summer than winter but was consistent with a difference in algal density and not cell specific $\mathrm{P}_{\max }$ gross; why this difference occurred is unknown. No seasonal change in the $95 \%$ saturation $\left(\mathrm{I}_{\mathrm{k}}\right)$ occurred, perhaps because a drop in $\mathrm{P}_{\max }$ gross corresponded with a drop in $\alpha$.

The effect of cloud cover on the photophysiology of A. aureoradiata was limited. However, there was an observed difference on cell specific $\mathrm{P}_{\max }$ gross at Kau Bay during summer, where the rate was greater on a sunny day compared with a cloudy day. The reasons for this remain unclear, however as there were no other differences for any other photosynthetic parameter due to cloud cover. It may be that cloud cover is not a major influence on the photophysiology of $A$. aureoradiata, or that prolonged periods of cover are required before an effect is induced. 


\subsubsection{How does habitat affect the photophysiology and respiration of A. aureoradiata?}

Kau Bay, a rocky inter-tidal site, and Pauatahanui Inlet, an estuarine mud-flat, are two contrasting habitats. Both habitats strongly influenced the photophysiology of $A$. aureoradiata, most likely through light availability and temperature. $\alpha$ was greater at Kau Bay than Pauatahanui Inlet during winter, suggesting that anemones from Kau Bay are more shade adapted than at Pauatahanui Inlet; temperature did not differ much between sites. From personal observation, A. aureoradiata from Kau Bay is found within cracks and crevices within the rocky inter-tidal zone and is obscured from direct sunlight for large periods of the day; indeed, in some cases anemones may be permanently obscured from direct sunlight. In contrast, A. aureoradiata from Pauatahanui Inlet is abundant at the surface of the mud flat at high tide and also in pools of water during low tide, and may be exposed for longer periods of time to direct sunlight. Furthermore, A. aureoradiata from Kau Bay is visibly darker than at Pauatahanui Inlet, perhaps reflecting differences in algal density, as anemones from Kau Bay do have greater algal densities than those at Pauatahanui Inlet; this is perhaps further evidence of shade adaptation. Also, while chlorophyll $a$ was not measured in this study, it is possible that the darker colouration of anemones at Kau Bay is related to a higher chlorophyll $a$ concentration per algal cell, which could contribute to the greater photosynthetic efficiency at this site.

Higher respiration rates at Kau Bay than at Pauatahanui Inlet during winter are most likely linked to differences in algal density, as temperatures did not differ substantially and would therefore be limited in their effect. The generally greater algal density at Kau Bay compared with Pauatahanui Inlet may therefore be responsible for the observed difference. The greater $I_{c}$ at Pauatahanui Inlet than at Kau Bay during 
summer on a cloudy day is related to a greater respiration rate and lower $\alpha$ at Pauatahanui Inlet, which again suggests that anemones from Kau Bay are more shade adapted than anemones from Pauatahanui Inlet. Cell specific $\mathrm{P}_{\max }$ gross showed no difference between habitats, however there was a difference in $\mathrm{P}_{\max }$ gross between habitats. $\mathrm{P}_{\max }$ gross was greater at Kau Bay during winter on sunny and cloudy days than at Pauatahanui Inlet under the same conditions. These differences appear to be due to algal density as opposed to cell specific $\mathrm{P}_{\max }$ gross. In support of this, McCloskey et al. (1994) studying the marine scyphomedusan Mastigias sp. reported greater photosynthetic rates within lagoon medusae compared with lake medusae due to increased algal densities found within lagoon medusae.

\subsubsection{Metabolic rate}

\subsubsection{Zooxanthellar biomass}

Muscatine (1980) states that algae comprise $3-23 \%$ of total protein biomass in any given association, indicating that zooxanthellae contribute minimally to respiration requirements (Muscatine et al. 1984; Steen and Muscatine 1984; Hoegh-Guldberg et al. 1986; McCloskey et al. 1994). However, in this study, zooxanthellae contributed substantially to symbiosis biomass $(32-69 \%)$ and therefore respiration, with peak contributions in summer. No other study has found algal biomass to contribute more than $50 \%$ of total biomass; the highest contribution reported for any other association is 47\% in the temperate octocoral Capnella gaboensis (Farrant et al. 1987b).

The assumption of the biomass ratio model, that algal - host respiration is proportional to algal - host biomass, is subjective (Muscatine et al. 1981), with evidence suggesting that the biomass - ratio model underestimates total zooxanthella 
respiration (Davy et al. 1996). For example, McCloskey and Muscatine (1984) found that the respiration rate of isolated zooxanthellae from the coral Stylophora pistillata was five - eight times that predicted by the biomass ratio model. However, they note that the procedure of zooxanthellar isolation most likely induces increased respiration. Furthermore, Smith and Muscatine (1986) predicted that the biomass-specific respiration rate would be greater by the zooxanthellae than host in the coral Montastrea annularis. Hence, algal respiration for A. aureoradiata in this study may be an underestimation; if zooxanthellae do contribute a greater amount to total respiration then it may be assumed that CZAR values would be lower than is shown.

\subsubsection{CZAR}

\subsubsection{Carbon translocation}

Photosynthetically fixed carbon translocated from algal symbionts to invertebrate hosts is a well established phenomenon (Muscatine et al. 1981), firmly supported by ${ }^{14} \mathrm{C}$ tracer studies (Smith 1974). High rates of carbon translocation result from a number of factors. First, high translocation reflects low rates of carbon utilisation by the symbionts for their own growth (Muscatine et al. 1983). Second, the symbiont translocates fixed carbon at higher rates under high irradiance as more photosynthetic product is available (Muscatine et al. 1983; Day 1994). This suggests that cnidarian species in areas exposed to high irradiance should receive larger amounts of fixed carbon from their symbionts than species in low light areas (Engebretson and Muller-Parker 1999) assuming photoinhibition is not occurring. This was supported by greater translocation

rates for A. aureoradiata during summer compared with winter and on a sunny day compared with a cloudy day at both field sites. 
Translocation rates are typically $>95 \%$ (Muscatine et al. 1984). In this study, rates of translocation where only comparable to this at Pauatahanui Inlet during summer on a sunny day where translocation was measured as $90.7 \%$; this suggests that more carbon is used for algal growth in A. aureoradiata than is suggested by Muscatine et al. 1984. Currently, the greatest known translocation rate determined for any association is that in the temperate zoanthid species Isozoanthus sulcatus, where zooxanthellae were estimated to translocate $>99 \%$ of fixed carbon at $1.5 \mathrm{~m}$ depth under sunny and cloudy conditions and at $9 \mathrm{~m}$ depth under sunny conditions (Davy et al. 1996).

\subsubsection{Daily CZAR}

The contribution of the zooxanthellae to the animal's daily energy requirements was estimated to be $>100 \%$ for A. aureoradiata at Kau Bay during summer on both sunny and cloudy days. This value, however, assumes that anemones were exposed to direct sunlight as irradiance measurements did not account for shading caused by inhabiting cracks and crevices. Nevertheless, this suggests that $A$. aureoradiata has the potential to be fully autotrophic in summer at Kau Bay, even if some anemones never achieved this potential. Alternatively, at Kau Bay during winter and at Pauatahanui Inlet during both summer and winter, A. aureoradiata is dependent to some degree on heterotrophic feeding, as the CZAR was $<100 \%$. At Kau Bay and Pauatahanui Inlet during winter, the CZAR was zero, due to the high algal respiration rate and low photosynthetic rate, which led to low rates of carbon translocation to the host. This suggests that zooxanthellae may be parasitic on the host at this time of year and is discussed further in chapter 4 .

CZAR estimates for the temperate North American anemone Anthopleura elegantissima are similarly variable. Fitt et al. (1982) estimated the CZAR to be 13 - 
$45 \%$ for fed and non-fed anemones, whilst Shick and Dykens (1984) estimated the CZAR as $34 \%$ for low intertidal species and $18 \%$ for high intertidal species. However, both these studies measured rates of translocation using ${ }^{14} \mathrm{C}$ and possibly underestimated the amount translocated, as ${ }^{14} \mathrm{C}$ may be released into the atmosphere as ${ }^{14} \mathrm{CO}_{2}$ and not counted (Muscatine et al. 1984). Employing the current method, Verde and McCloskey (1996b) estimated the CZAR in A. elegantissima, collected from the inter-tidal zone and kept at $12-14^{\circ} \mathrm{C}$ for 48 hours, to be $48.4 \%$ and more recently Verde and McCloskey (2007) estimated it to vary from $\sim 60-\sim 130 \%$ over the course of a year. Additionally, Davy et al. (1996), investigating the CZAR of four temperate cnidarians from Southern Eire, made comparisons between irradiance regimes experienced at depths of 1.5 and $9 \mathrm{~m}$ on sunny and cloudy days in summer. They found that Anemonia viridis (CZAR, 140.6 - 142.9\%) and Isozoanthus sulcatus (CZAR, $181.5 \%$ ) on sunny days at $1.5 \mathrm{~m}$ had CZAR values greatly over $100 \%$, while Cereus pedunculatus (CZAR, 72.1\%) and Anthopleura ballii (CZAR, 72.6\%) are dependent on some form of heterotrophic uptake to maintain their energy balance, even in well lit conditions. However, on cloudy days or at less favourable irradiances, the CZAR values were $<100 \%$ for Anemonia viridis (CZAR, $3.3-71.2 \%$ ) and very low for Cereus pedunculatus (CZAR, 0.7 - 26.6\%), and Anthopleura ballii (CZAR, 2.1 43.5\%); the CZAR in Isozoanthus sulcatus ranged from 59.5 - $161.3 \%$ under these conditions.

In tropical cnidarian species, the CZAR has been regularly estimated as $>100 \%$, due to the high light environment. Exceptions include two species of zoanthids, Zoanthus sociatus (48\%) and Palythoa variabilis (13\%), that are dependent on heterotrophy (Steen and Muscatine 1984). Furthermore, Day (1994) determined a CZAR of $92.4 \%$ for the anemone Bunodeopsis globulifera, yet determined a CZAR of 
108.5\% for Bunodeopsis antilliensis. Further estimates have been determined for the giant clam Tridacna gigas (100\%) (Fisher et al. 1985) and the coral, Stylophora pistillata (143\%) (Muscatine et al. 1984). Davies (1991), studying three species of coral (Pocillopora damicornis, Montipora verrucosa and Porites lobata), predicted that on a "normal" day with intermittent cloud cover and on an "ideal" cloudless day the corals could survive autotrophically. He suggested that excess carbon stored on normal and ideal days is used to support metabolic requirements on overcast days when energy budgets are in deficit. This could also apply to A. aureoradiata; energy reserves may help it feed autotrophically at times where the energy budget is in deficit or may be used in reproduction. However, during periods when autotrophy is very low or not possible, A. aureoradiata may need to feed heterotrophically to satisfy its metabolism. This is most obvious during the winter months and during the summer at Pauatahanui Inlet. At Pauatahanui Inlet, high amounts of particulate matter may result in less dependence on autotrophy throughout the year. Dependence on heterotrophy has been shown to not limit the temperate anemone A. elegantissima. For instance, this species may obtain $>2.5 \mathrm{mg} \mathrm{C} \mathrm{day}^{-1}$ by prey capture (Shick, Zanier, pers. comms. cited in Verde and McCloskey 1996a). Furthermore, when Anemonia viridis and Anthopleura ballii were caged in the field and shaded but allowed to feed heterotrophically, changes in body weight were insignificant, suggesting that anemones could survive heterotrophically (Davy et al. 1997). Therefore autotrophy is perhaps not as important to A. aureoradiata as has been shown to be the case with tropical cnidarians. 


\subsubsection{Further studies}

To gain a more complete understanding of A. aureoradiata under field conditions measurements of salinity, nutrient fluxes and UV could have been incorporated into this study as well as chlorophyll $a$ analysis. Additionally, measurements of irradiance for anemones in situ over a day i.e. in their crevices or taking account of burrowing on the mud flat would also be useful. Furthermore, a long term study over a year to model the extent of autotrophy vs. heterotrophy will also give a more complete understanding of this symbiosis. Future research into the symbiosis between A. aureoradiata and its zooxanthellae could focus on the effects of heterotrophic feeding, irradiance and, temperature. Chapter 3 focuses on the effects of temperature on the photophysiology, algal density and growth rate and CZAR of $A$. aureoradiata in order to understand the capacity of this symbiotic anemone to survive in its highly variable temperate habitat. 


\section{Chapter 3:}

\section{The effect of temperature on carbon flux in the symbiotic intertidal sea anemone Anthopleura aureoradiata.}

\subsection{Introduction}

A majority of cnidarians contain endosymbiotic algae ("zooxanthellae"). Carbon fixed photosynthetically by the zooxanthellae is translocated to the host for use in host respiration, growth and reproduction (Muscatine et al. 1984). It is estimated that $>95 \%$ of total carbon fixed is translocated to the host (Muscatine et al. 1983; Muscatine et al. 1984) in the form of glycerol, amino acids and carbohydrates (Muscatine 1967; Sutton and Hoegh-Guldberg 1990; Bil et al. 1992). In return, the symbiont gains access to nitrogen and phosphorus, in the form of metabolic waste products from the host (Dubinsky and Jokiel 1994).

Latitudinal differences in temperature are an important influence on global symbiotic cnidarian distribution patterns (Kleypas et al. 1999). Seawater temperature has been suggested to limit the latitudinal distribution of corals (Kleypas et al. 1999). This is as coral growth decreases with increasing latitude, to a point beyond $25^{\circ} \mathrm{N}$ and $25^{\circ} \mathrm{S}$ where coral-reef development no longer occurs (Grigg 1982). Sea surface temperatures reported from tropical regions have been recorded as $28.1^{\circ} \mathrm{C} \pm 3^{\circ} \mathrm{C}$ from Discovery Bay, Jamaica (Webber and Roff 1995), $31.5-31.8^{\circ} \mathrm{C}$ from the Red Sea and $33.6-34.4^{\circ} \mathrm{C}$ from the Persian Gulf (Kleypas et al. 1999). Most reef corals cannot withstand temperatures below $18^{\circ} \mathrm{C}$ (Dana 1843; Vaughan 1918 cited in Saxby et al. 
2003) as both photosynthesis and respiration are usually impaired at temperatures below this (Crossland 1984).

Temperature ranges for temperate regions inhabited by symbiotic cnidarians are substantially lower than for tropical regions. For instance sea temperatures on sunny days reported from the inter-tidal zone vary from $9.8-15.5^{\circ} \mathrm{C}$ between winter and summer at Kau Bay (a rocky shore), Wellington, New Zealand, home of the anemone Anthopleura aureoradiata (see Chapter 2). Additionally, McNaughtan (2008), over a sampling period from Aug - Dec 2006 in Wellington, New Zealand, reported a minimum tide pool temperature of $9.3^{\circ} \mathrm{C}$ during August (winter) compared with a maximum temperature of $25.7^{\circ} \mathrm{C}$ during December (summer); furthermore daily temperature over $24 \mathrm{hrs}$ during one day in September varied from $10-20.5^{\circ} \mathrm{C}$. Such a wide daily range is also experienced by the temperate North American sea anemone Anthopleura elegantissima that has been shown to experience temperature fluctuations from $14-31^{\circ} \mathrm{C}$ (Jensen and Muller-Parker 1994). While the low temperatures experienced by these sea anemones are likely to limit respiration and photosynthesis (Navarro et al. 1981; Howe and Marshall 2001; Nakamura et al. 2003), these symbioses are otherwise regarded as highly robust and thermally tolerant of the environmental conditions they experience.

The temperate symbiotic sea anemone A. aureoradiata is common throughout New Zealand's inter-tidal zone. It may be found within estuarine mud-flats or on rocky inter-tidal shores. Within the mud-flat, A. aureoradiata is commonly found attached to the cockle Austrovenus stutchburyi, $1-2 \mathrm{~cm}$ or so below the surface of the mud, and at times may be observed with its oral disc and tentacles displayed above the surface of the mud-flat. On rocky shores, A. aureoradiata may be found aggregated in cracks or crevices attached to rocks in tide pools throughout the upper and mid littoral zone. 
Over the past 100 years increased atmospheric $\mathrm{CO}_{2}$ has caused a $0.74^{\circ} \mathrm{C}$ in global average sea surface temperature (IPCC 2007 cited in Hoegh-Guldberg et al. 2007). Ocean temperatures are predicted to warm a further $2^{\circ} \mathrm{C}$ by $2050-2100$ (Hoegh-Guldberg et al. 2007). Consequently, current temperatures have pushed many tropical cnidarians close to their thermal limits as temperature increases of $1-2^{\circ} \mathrm{C}$ over a period of $5-10$ weeks during summer will induce bleaching (Goreau and Hayes 1994; Brown et al. 1997). For temperate symbiotic cnidarians, studies on the effects of temperature on their physiology are limited. A comparison of thermal metabolic responses in the temperate sea anemone $A$. aureoradiata may shed some light on the processes involved in the adaptation or acclimation of temperate species to temperate seas and future consequences of global warming. This study aims to address the following questions:

1. How do gradual and rapid temperature changes affect the density and growth of the symbiotic algae?

2. How do gradual and rapid temperature changes affect the photophysiology of A. aureoradiata?

3. How do gradual and rapid temperature changes affect the contribution of zooxanthellae to the respiratory requirements (CZAR) of A. aureoradiata? 


\subsection{Materials and methods}

\subsubsection{Anemone collection and maintenance}

Anthopleura aureoradiata specimens were collected from Pauatahanui Inlet 2 weeks before experimentation. All anemones were collected from the inter-tidal zone at a depth of $1-2 \mathrm{~cm}$ below the mud surface from the shells of the cockle Austrovenus stutchburyi. Anemones were maintained in a large glass bowl $\left(30 \mathrm{~cm}^{3}\right)$ under laboratory conditions of $15.5^{\circ} \mathrm{C} \pm 1^{\circ} \mathrm{C}, 80 \mu \mathrm{mol}$ photons $\mathrm{m}^{-2} \mathrm{~s}^{-1}$ and $35 \mathrm{ppt}$ in $1-\mu \mathrm{m}$ filtered seawater (FSW). Anemones were fed twice weekly in the evening with Artemia sp. nauplii and the FSW was changed the next morning. No photosynthetic measurements were performed on the day the FSW was changed.

\subsubsection{Photosynthesis and respiration measurements}

Oxygen flux of A. aureoradiata was examined by comparing gradual temperature changes (GTC) and rapid temperature changes (RTC). Seven temperature regimes were compared: $5^{\circ} \mathrm{C}, 10^{\circ} \mathrm{C}, 15^{\circ} \mathrm{C}, 25^{\circ} \mathrm{C}, 30^{\circ} \mathrm{C}, 32.5^{\circ} \mathrm{C}$ and $35^{\circ} \mathrm{C} \pm 1^{\circ} \mathrm{C}$. Prior to the generation of a photosynthesis-irradiance $(\mathrm{P}-\mathrm{I})$ curve, anemones $(\mathrm{n}=4)$ were placed in a clear glass cylindrical chamber ( $14 \mathrm{ml}$ volume), containing FSW (35 ppt) at $15.5^{\circ} \mathrm{C} \pm 1^{\circ} \mathrm{C}$ situated in a perspex water bath. The chamber was illuminated at $80 \mu \mathrm{mol}$ photons $\mathrm{m}^{-2}$ $\mathrm{s}^{-1}$ using a halogen dichroic PAR (photosynthetically active radiation) $12 \mathrm{~V} 50 \mathrm{~W} 13^{\circ}$ lamp, and the anemones allowed to settle for approximately $60 \mathrm{~min}$. Irradiance incident on the anemones was measured using a cylindrical clear perspex chamber (as the light meter probe was not able to fit into the smaller glass chamber) situated in the water bath and a LI-COR LI-1000 irradiance data logger. The chamber was situated on top of an underwater magnetic stirrer (Variomag Compact), and inside the chamber a 
magnetic spin bar spun at the maximum rate at which the anemones did not appear stressed. The spin bar provided an even distribution of oxygen within the chamber. The spin bar was overlaid by a perforated plastic floor and a layer of nylon mesh, on which the anemones were placed. Following this settlement period, for a P-I curve experiencing a GTC, the temperature was either increased or decreased by $5^{\circ} \mathrm{C}$ and the anemones left at this new temperature for 30 min before the temperature was once again decreased or increased by $5^{\circ} \mathrm{C}$. This procedure was repeated until the desired temperature was attained at which a P-I curve was then generated. For controls, the temperature was maintained at $15^{\circ} \mathrm{C} \pm 1^{\circ} \mathrm{C}$ and the anemones allowed to settle for the same amount of time it took for the temperature in the GTC experiment to reach its desired level. Prior to sealing with a rubber bung, FSW inside the chamber was switched with $100 \% \mathrm{O}_{2}$ saturated FSW. The oxygen and temperature sensors were inserted through this bung; these were connected to a Fibox 3 temperature-compensated oxygen meter, linked to a laptop which used the Fibox 3 computer software as a chart recorder. Calibration of the oxygen and temperature sensors involved preparation of oxygen free FSW $(0 \%)$ using $1 \mathrm{~g}$ sodium sulfite $\left(\mathrm{Na}_{2} \mathrm{SO}_{3}\right)$ per $100 \mathrm{ml} \mathrm{FSW}$, and stirring for $30 \mathrm{sec}$. Alternatively, air saturated FSW (100\%) was created using an air pump to blow air into $100 \mathrm{ml}$ of FSW for $20 \mathrm{~min}$.

The rate of respiration $\left(\mathrm{ml} \mathrm{O}_{2} \mathrm{~h}^{-1}\right)$ of anemones was measured in darkness for 45 minutes. The PAR lamp was then switched on and the rate of net photosynthesis measured up to $200 \mu \mathrm{mol}$ photons $\mathrm{m}^{-2} \mathrm{~s}^{-1}$, in increments of $20 \mu \mathrm{mol}$ photons $\mathrm{m}^{-2} \mathrm{~s}^{-1}$. From $200 \mu \mathrm{mol}$ photons $\mathrm{m}^{-2} \mathrm{~s}^{-1}$ the irradiance was increased in $40 \mu \mathrm{mol}$ photons $\mathrm{m}^{-2} \mathrm{~s}^{-1}$ steps until $400 \mu \mathrm{mol}$ photons $\mathrm{m}^{-2} \mathrm{~s}^{-1}$ was reached, after which the irradiance was increased in $100 \mu \mathrm{mol}$ photons $\mathrm{m}^{-2} \mathrm{~s}^{-1}$ steps until an irradiance of $900 \mu \mathrm{mol}$ photons $\mathrm{m}^{-2}$ $\mathrm{s}^{-1}$ was reached. Photosynthesis at each irradiance was measured until constant, which 
took about 10 min. Preparation of a RTC treatment P-I curve required anemones being settled for $60 \mathrm{~min}$ at $15.5^{\circ} \mathrm{C} \pm 1^{\circ} \mathrm{C}, 35 \mathrm{ppt}$ and $80 \mu \mathrm{mol}$ photons $\mathrm{m}^{-2} \mathrm{~s}^{-1}$ after which the FSW inside the chamber was replaced with $100 \% \mathrm{O}_{2}$ saturated FSW at the treatment temperature and $\mathrm{O}_{2}$ measurements begun within 1 min.

Once each P-I curve was complete, the corresponding anemones $(n=4)$ were homogenised and zooxanthellar counts taken as described in Chapter 2. Subsequently, animal protein content was measured, again as described in Chapter 2.

\subsubsection{Determination of Mitotic Index (MI)}

Diel mitotic activity was measured to determine the growth rate of algae at the temperature treatments of $5^{\circ} \mathrm{C}, 10^{\circ} \mathrm{C}, 15^{\circ} \mathrm{C}, 25^{\circ} \mathrm{C}, 30^{\circ} \mathrm{C}, 32.5^{\circ} \mathrm{C}$ and $35^{\circ} \mathrm{C}$ for gradual and rapid temperature changes. Anemones $(n=5)$ were placed in a clear glass cylindrical chamber containing FSW (35 ppt) at $15.5^{\circ} \mathrm{C} \pm 1^{\circ} \mathrm{C}$. The chamber was illuminated at $80 \mu \mathrm{mol}$ photons $\mathrm{m}^{-2} \mathrm{~s}^{-1}$ and the anemones allowed to settle for $60 \mathrm{~min}$. In preparation of the MI, anemones were treated as before for GTC or RTC. Sampling of the MI occurred every $3 \mathrm{~h}$ whereby a tentacle from $A$. aureoradiata was snipped off and smeared across a slide, with a drop of FSW and a coverslip placed on top. A cell was considered to be dividing (i.e. undergoing mitosis) if it appeared as a doublet with a cell plate (magnification x 100). The dividing cells in five samples each of 300 cells, were averaged and the resultant percentage taken as the MI (Wilkerson et al. 1983). The MI was assumed to be asynchronous over the sampling period of a day (see Chapter 2). 


\subsubsection{Contribution of zooxanthellae to animal respiration (CZAR)}

The CZAR was calculated from $\mathrm{O}_{2}$ flux measurements as described in Appendix A. Pgross was assumed for 12 hours at saturation irradiance with respiration occurring over 24 hours. Algal respiration was assumed to be proportional to algal biomass (see Appendix A) over $24 \mathrm{~h}$ and was subtracted from Pgross to estimate $\mathrm{P}_{\mathrm{z}}(\mathrm{net})$ :

Equation 3.1: $\quad \mathrm{P}_{\mathrm{Z}}$ (net) $=\mathrm{P}($ gross $)(12$ hours $)-\mathrm{R}_{\mathrm{Z}}(24$ hours $)$

Where $\mathrm{P}_{\mathrm{z}}($ net $)=$ net zooxanthellar photosynthesis over 12 hours, $\mathrm{P}($ gross $)=\mathrm{P}($ net $)+\mathrm{R}_{\mathrm{s}}$ (whole symbiosis respiration) and $\mathrm{R}_{\mathrm{z}}=$ algal respiration over $24 \mathrm{~h}$ and is subtracted due to the 24 hourly nature of the translocation estimate.

$\mathrm{P}_{\mathrm{z}}$ (net) was then used to calculate the CZAR over $24 \mathrm{~h}$ :

Equation 3.2: $\quad \operatorname{CZAR}=\frac{\underline{P}_{z} \text { (net) } \times T}{R_{a}}$

Where $\mathrm{P}_{\mathrm{z}}=$ net algal photosynthesis over 12 hours, $\mathrm{T}=$ percentage of photosynthate translocated and represents carbon supply to the animal, $\mathrm{R}_{\mathrm{a}}=$ animal respiration over 24 $\mathrm{h}$ and represents carbon demand by the animal. 


\subsubsection{Statistical Analyses}

All statistical analyses was carried out using SPSS@ 14.0 for Windows. One-way ANOVA was used to determine differences between GTC and RTC. Analysis of these differences was further inspected by Post Hoc Tukey HSD tests to search for any disparity between treatments. Comparisons between corresponding temperatures when the temperature was changed gradually or rapidly were performed by Two Sample TTests. 


\subsection{Results}

\subsubsection{Algal and symbiosis biomass characteristics}

Algal and symbiosis biomass characteristics are shown for GTC and RTC in Tables 3.1 and 3.2 (Appendix D, Table 5.9 displays control temperature algal and symbiosis biomass characteristics). There were no significant differences in algal density due to GTC (ANOVA, $\mathrm{F}_{6,28}=2, \mathrm{p}=0.095$ ) or RTC (ANOVA, $\mathrm{F}_{6,28}=1.5, \mathrm{P}=0.214$ ), and similarly no significant differences in density between GTC and RTC treatments for corresponding temperatures (Two sample T-Test $>0.05$ ). 
Table 3.1 Algal and symbiosis biomass characteristics (means \pm 1 SE) for Anthopleura aureoradiata from gradual temperature changes. $\mathrm{n}=100$ for zooxanthellae diameter, $n=5$ for all other measurements; except $n=4$ for $15^{\circ} \mathrm{C}$ and $n=6$ for $30^{\circ} \mathrm{C}$

\begin{tabular}{|c|c|c|c|c|c|c|c|}
\hline Characteristic & $5^{\circ} \mathrm{C}$ & $10^{\circ} \mathrm{C}$ & $15^{\circ} \mathrm{C}$ & $25^{\circ} \mathrm{C}$ & $30^{\circ} \mathrm{C}$ & $32.5^{\circ} \mathrm{C}$ & $35^{\circ} \mathrm{C}$ \\
\hline $\begin{array}{l}\text { Algal cell diameter } \\
\qquad(\mu \mathrm{m})\end{array}$ & $10.58 \pm 0.11$ & $10.58 \pm 0.1$ & $10.2 \pm 0.1$ & $9.88 \pm 0.11$ & $9.99 \pm 0.09$ & $10.18 \pm 0.09$ & $10.6 \pm 0.11$ \\
\hline $\begin{array}{l}\text { Algal cell volume } \\
\qquad\left(\mu^{3}\right)\end{array}$ & 618.9 & 618.9 & 555.37 & 503.95 & 521.37 & 551.29 & 623.3 \\
\hline $\begin{array}{l}\text { Derived algal cell carbon } \\
\quad\left(\text { pg C cell }{ }^{-1}\right)\end{array}$ & 90.69 & 90.69 & 82.57 & 75.9 & 78.17 & 82.04 & 91.24 \\
\hline $\begin{array}{l}\text { Derived algal cell protein } \\
\quad\left(\text { pg protein cell }{ }^{-1}\right)\end{array}$ & 92.92 & 92.92 & 84.6 & 77.77 & 80.09 & 84.06 & 93.49 \\
\hline$\underset{(\mathbf{p g})}{\mathbf{N} \text { content per cell }}$ & 14.87 & 14.87 & 13.54 & 12.44 & 12.82 & 13.45 & 14.96 \\
\hline $\begin{array}{l}\text { Total no. of algae per anemone } \\
\qquad\left(\mathrm{x10}^{6}\right)\end{array}$ & $5.11 \pm 0.6$ & $4.35 \pm 0.17$ & $6.72 \pm 0.69$ & $6.68 \pm 0.74$ & $4.63 \pm 0.38$ & $1.8 \pm 0.08$ & $3.03 \pm 0.49$ \\
\hline$\underset{(\mu \mathrm{g})}{\text { Total animal protein }}$ & $325.61 \pm 26.72$ & $317.81 \pm 20.63$ & $373.61 \pm 64.49$ & $368.38 \pm 26.16$ & $291.23 \pm 18.89$ & $143.81 \pm 12.48$ & $231.03 \pm 33.61$ \\
\hline $\begin{array}{c}\text { Algal density } \\
\left(\text { algae } \mu^{-1} \text { protein } \times 10^{3}\right)\end{array}$ & $15.52 \pm 0.71$ & $14.02 \pm 1.37$ & $19.63 \pm 4.26$ & $18.02 \pm 0.99$ & $17.63 \pm 1.62$ & $13.11 \pm 0.86$ & $13.15 \pm 0.67$ \\
\hline $\begin{array}{l}\text { Total algal protein } \\
\text { (mg) }\end{array}$ & $1.44 \pm 0.07$ & $1.3 \pm 0.13$ & $1.66 \pm 0.36$ & $1.4 \pm 0.08$ & $1.41 \pm 0.13$ & $1.1 \pm 0.07$ & $1.23 \pm 0.06$ \\
\hline Algal: Total protein ratio & $0.59 \pm 0.01$ & $0.56 \pm 0.02$ & $0.61 \pm 0.04$ & $0.58 \pm 0.01$ & $0.58 \pm 0.02$ & $0.52 \pm 0.02$ & $0.54 \pm 0.01$ \\
\hline $\begin{array}{c}\text { Derived algal carbon standing stock } \\
\left(\mathbf{C}^{\prime}\right) \\
\left(\mu \mathrm{g} \mathrm{C} \mu \mathrm{g}^{-1} \text { protein }\right)\end{array}$ & $1.41 \pm 0.06$ & $1.27 \pm 0.12$ & $1.62 \pm 0.35$ & $1.37 \pm 0.08$ & $1.38 \pm 0.13$ & $1.08 \pm 0.07$ & $1.2 \pm 0.06$ \\
\hline
\end{tabular}


Table 3.2 Algal and symbiosis biomass characteristics (means \pm 1 SE) for Anthopleura aureoradiata from rapid temperature changes. $\mathrm{n}=100$ for zooxanthellae diameter, otherwise $\mathrm{n}=5$ for all other measurements.

\begin{tabular}{|c|c|c|c|c|c|c|c|}
\hline Characteristic & $5^{\circ} \mathrm{C}$ & $10^{\circ} \mathrm{C}$ & $15^{\circ} \mathrm{C}$ & $25^{\circ} \mathrm{C}$ & $30^{\circ} \mathrm{C}$ & $32.5^{\circ} \mathrm{C}$ & $35^{\circ} \mathrm{C}$ \\
\hline $\begin{array}{l}\text { Algal cell diameter } \\
\qquad(\mu \mathrm{m})\end{array}$ & $10.54 \pm 0.1$ & $10.05 \pm 0.14$ & $10.51 \pm 0.09$ & $10.35 \pm 0.1$ & $9.99 \pm 0.1$ & $10.68 \pm 0.1$ & $10.08 \pm 0.09$ \\
\hline $\begin{array}{l}\text { Algal cell volume } \\
\qquad\left(\mu^{3}\right)\end{array}$ & 612.34 & 531.22 & 607.99 & 580.23 & 521.37 & 637.74 & 535.2 \\
\hline $\begin{array}{l}\text { Derived algal cell carbon } \\
\left(\mathrm{pg} C \text { cell }^{-1}\right)\end{array}$ & 89.85 & 79.45 & 89.3 & 85.76 & 78.17 & 93.07 & 79.96 \\
\hline $\begin{array}{l}\text { Derived algal cell protein } \\
\quad\left(\mathrm{pg} \text { protein cell }{ }^{-1}\right)\end{array}$ & 92.06 & 81.4 & 91.5 & 87.87 & 80.1 & 95.36 & 81.93 \\
\hline $\begin{array}{l}\mathrm{N} \text { content per cell } \\
(\mathrm{pg})\end{array}$ & 14.73 & 13.02 & 14.64 & 14.06 & 12.82 & 15.26 & 13.11 \\
\hline $\begin{array}{l}\text { Total no. of algae per anemone } \\
\qquad\left(\mathbf{x 1 0}^{6}\right)\end{array}$ & $4.59 \pm 0.31$ & $4.68 \pm 0.56$ & $3.8 \pm 0.5$ & $4.28 \pm 0.49$ & $3.43 \pm 0.64$ & $1.91 \pm 0.13$ & $1.65 \pm 0.34$ \\
\hline $\begin{array}{c}\text { Total animal protein } \\
(\mu \mathrm{g})\end{array}$ & $321.42 \pm 64.27$ & $255.05 \pm 38.88$ & $180.09 \pm 20.46$ & $319.17 \pm 69.01$ & $190.99 \pm 38.2$ & $131.61 \pm 13.47$ & $73.38 \pm 7.44$ \\
\hline $\begin{array}{c}\text { Algal density } \\
\left(\text { algae } \text { mg }^{-1} \text { protein } \mathbf{x 1 0}^{6}\right)\end{array}$ & $16.14 \pm 2.33$ & $19.19 \pm 1.99$ & $21.26 \pm 1.62$ & $14.64 \pm 2.25$ & $18.2 \pm 1.58$ & $15.11 \pm 1.7$ & $23.97 \pm 5.65$ \\
\hline $\begin{array}{l}\text { Total algal protein } \\
\text { (mg) }\end{array}$ & $1.49 \pm 0.21$ & $1.56 \pm 0.16$ & $1.95 \pm 0.15$ & $1.29 \pm 0.2$ & $1.46 \pm 0.13$ & $1.44 \pm 0.16$ & $1.96 \pm 0.46$ \\
\hline Algal: Total protein ratio & $0.59 \pm 0.04$ & $0.6 \pm 0.03$ & $0.66 \pm 0.02$ & $0.55 \pm 0.04$ & $0.59 \pm 0.02$ & $0.58 \pm 0.03$ & $0.63 \pm 0.06$ \\
\hline 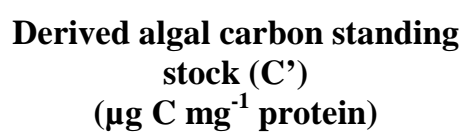 & $1.44 \pm 0.21$ & $1.52 \pm 0.16$ & $1.9 \pm 0.15$ & $1.26 \pm 0.19$ & $1.42 \pm 0.12$ & $1.41 \pm 0.16$ & $1.92 \pm 0.45$ \\
\hline
\end{tabular}




\subsubsection{Mitotic index}

The averaged mitotic index (MI) over the course of light hours for GTC and RTC is shown in Fig 3.1 (Appendix C, Figs 5.1 and 5.2 displays the daily cycle for the MI under GTC and RTC treatments). Appendix D, Tables 5.12 and 5.18 display post-hoc Tukey HSD comparisons for GTC and RTC treatments. There was a significant difference in MI within GTC treatment (ANOVA, $\mathrm{F}_{6,133}=5.8, \mathrm{P}<0.001$ ) and RTC treatment (ANOVA, $\left.\mathrm{F}_{6,133}=3.65, \mathrm{P}=0.002\right)$. However, the averaged MI over the course of a day displayed no consistent pattern for GTC and RTC treatments. In response to GTC, the MI was greatest at $32.5^{\circ} \mathrm{C}(2.2 \%)$ and lowest at $25^{\circ} \mathrm{C}(0.7 \%)$ (one-way ANOVA, post-hoc Tukey HSD, p < 0.001). In comparison the MI under RTC also peaked at $32.5^{\circ} \mathrm{C}(2.3 \%)$ but was lowest at $10^{\circ} \mathrm{C}(1 \%)$ (one-way ANOVA, posthoc Tukey HSD, $\mathrm{p}=0.019)$. When MI was compared between corresponding temperatures under GTC and RTC treatments, there were no significant differences (Two sample T-Test > 0.05).

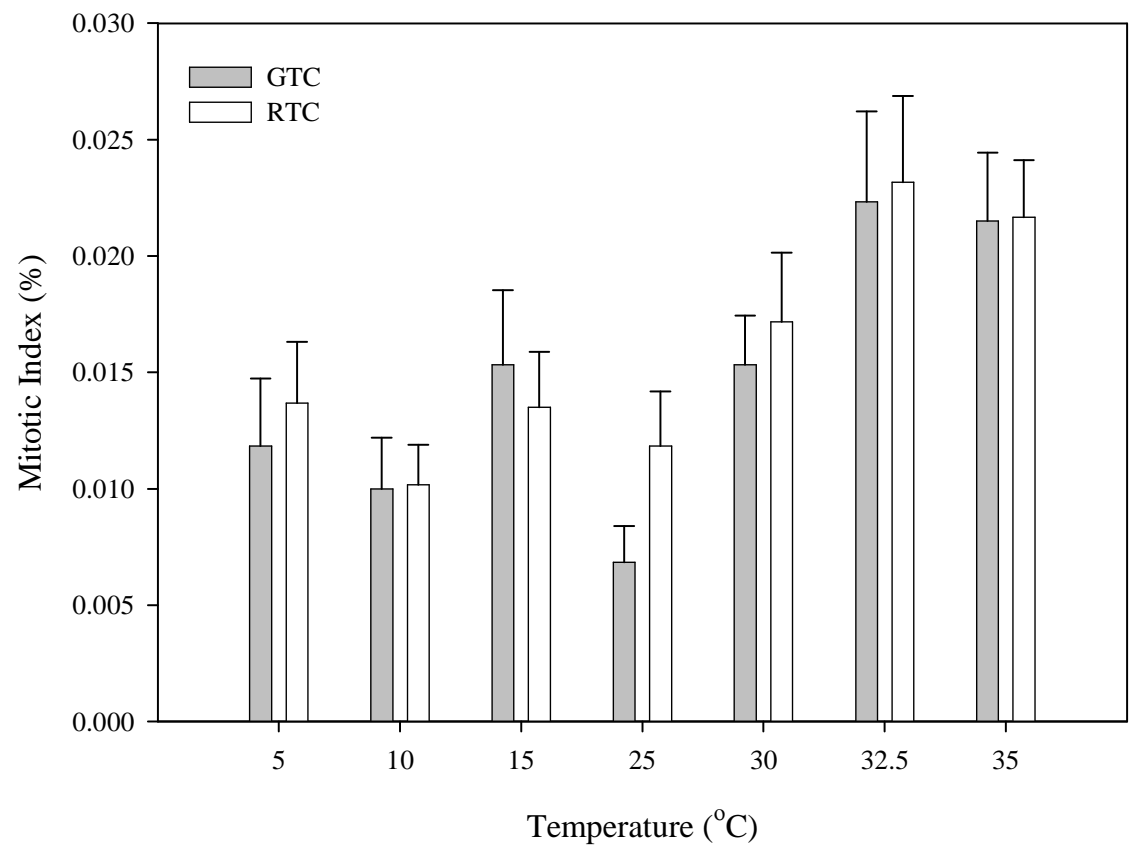

Figure 3.1. Mitotic index for Anthopleura aureoradiata under gradual and rapid temperature change treatments; $n=20$; Values are mean \pm 1 SE. 


\subsubsection{Photosynthesis vs. irradiance}

Plots of gross photosynthesis versus irradiance (P - I curves) for Anthopleura aureoradiata exposed to gradual temperature change (GTC) (Fig. 3.2A) and rapid temperature change (RTC) (Fig. 3.2B) are shown. Figs. $3.3 \mathrm{~A}-\mathrm{F}$ summarise the associated P - I parameters for GTC, RTC and control treatments. Appendix D, Tables $5.11-5.16$ and $5.19-5.24$ display post-hoc Tukey HSD tests for these photosynthetic parameters.

\section{Photosynthetic efficiency $(\alpha)$}

There was a significant difference in $\alpha$ (Fig. 3.3A) due to both GTC (one-way ANOVA, $\mathrm{F}_{6,28}=9.32, \mathrm{p}<0.001$ ) and RTC (one-way ANOVA, $\mathrm{F}_{6,28}=16.59, \mathrm{P}<$ 0.001). Under GTC, $\alpha$ did not vary between $5^{\circ} \mathrm{C}-15^{\circ} \mathrm{C}$ (one-way ANOVA, post-hoc Tukey HSD, $p>0.05$ ) but increased significantly, by $2.6-4.5$ times, between $25^{\circ} \mathrm{C}-$ $32.5^{\circ} \mathrm{C}$ (one-way ANOVA, post-hoc Tukey HSD, p < 0.043), before significantly decreasing by $35^{\circ} \mathrm{C}$ (one-way ANOVA, post-hoc Tukey HSD, $\mathrm{p}=0.015$ ). In comparison, $\alpha$ under RTC displayed no change between $5^{\circ} \mathrm{C}-30^{\circ} \mathrm{C}$ (one-way ANOVA, Post-hoc Tukey HSD, $\mathrm{p}>0.05)$; indeed at $35^{\circ} \mathrm{C}, \alpha$ was significantly greater than at $5^{\circ} \mathrm{C}-32.5^{\circ} \mathrm{C}$ (one-way ANOVA, post-hoc Tukey HSD, p <0.001). The rate of $\alpha$ was also significantly greater at $35^{\circ} \mathrm{C}$ under the $\mathrm{RTC}$ treatment than at $35^{\circ} \mathrm{C}$ under GTC $\left(\mathrm{T}_{8}=2.84, \mathrm{p}=0.022\right)$, while all other RTC vs. GTC comparisons were not significant (Two sample T-Test >0.05).

\section{Respiration rate}

Significant differences were observed in the respiration rates (Fig. 3.3B) under GTC (ANOVA, $\left.\mathrm{F}_{6,28}=33, \mathrm{P}<0.001\right)$ and RTC (ANOVA, $\left.\mathrm{F}_{6,28}=36.39, \mathrm{P}<0.001\right)$ treatments. Respiration rate did not change between $5^{\circ} \mathrm{C}-15^{\circ} \mathrm{C}$ (one-way ANOVA, post-hoc Tukey HSD, p >0.05) under GTC, but were significantly greater at $25^{\circ} \mathrm{C}-$ $35^{\circ} \mathrm{C}$ (one-way ANOVA, post-hoc Tukey HSD, $\mathrm{p}<0.041$ for all comparisons). The 
rate at $32.5^{\circ} \mathrm{C}$ was also significantly greater than at $25^{\circ} \mathrm{C}-35^{\circ} \mathrm{C}$ (one-way ANOVA, post-hoc Tukey HSD, $\mathrm{p}<0.021$ for all comparisons). Rates of respiration under RTC did not vary between $5^{\circ} \mathrm{C}-15^{\circ} \mathrm{C}$ (one-way ANOVA, post-hoc Tukey HSD, p > 0.05), but were significantly greater at $25^{\circ} \mathrm{C}-35^{\circ} \mathrm{C}$ than at $5^{\circ} \mathrm{C}$ (one-way ANOVA, post-hoc Tukey HSD, $\mathrm{p}<0.014$ for all comparisons) and also were significantly greater at $30^{\circ} \mathrm{C}$ - $35^{\circ} \mathrm{C}$ than at $10^{\circ} \mathrm{C}-25^{\circ} \mathrm{C}$ (one-way ANOVA, post-hoc Tukey HSD, $\mathrm{p}<0.043$ for all comparisons). Respiration rate was also significantly greater at $35^{\circ} \mathrm{C}$ than at $30^{\circ} \mathrm{C}$ and $32.5^{\circ} \mathrm{C}$ (one-way ANOVA, post-hoc Tukey HSD, $\mathrm{p}<0.008$ for both comparisons). Rates of respiration were significantly greater under RTC than $\mathrm{GTC}$ at $10^{\circ} \mathrm{C}\left(\mathrm{T}_{8}=3.91\right.$, $\mathrm{p}=0.004), 15^{\circ} \mathrm{C}\left(\mathrm{T}_{7}=3.69, \mathrm{p}=0.008\right), 30^{\circ} \mathrm{C}\left(\mathrm{T}_{9}=3.05, \mathrm{p}=0.014\right)$ and $35^{\circ} \mathrm{C}\left(\mathrm{T}_{8}=\right.$ $4.44, \mathrm{p}=0.002)$

\section{Compensation irradiance $\left(\mathbf{I}_{\mathbf{c}}\right)$}

There was a significant difference in $\mathrm{I}_{\mathrm{c}}$ (Fig. 3.3C) due to both GTC (ANOVA, $\left.\mathrm{F}_{4,20}=23.36, \mathrm{P}<0.001\right)$ and RTC (ANOVA, $\left.\mathrm{F}_{4,15}=5.98, \mathrm{P}=0.004\right)$ (Fig. 3.2E). $\mathrm{I}_{\mathrm{c}}$ was not significantly different over $5^{\circ} \mathrm{C}-15^{\circ} \mathrm{C}$ under GTC (one-way ANOVA, posthoc Tukey HSD, $\mathrm{p}>0.05$ ), but was significantly greater at $25^{\circ} \mathrm{C}-30^{\circ} \mathrm{C}$ than at $5^{\circ} \mathrm{C}-$ $15^{\circ} \mathrm{C}$ (one-way ANOVA, post-hoc Tukey HSD, $\mathrm{p}<0.034$ ). In comparison, $\mathrm{I}_{\mathrm{c}}$ under RTC was not significantly different over $5^{\circ} \mathrm{C}-15^{\circ} \mathrm{C}$ (one-way ANOVA, post-hoc Tukey HSD, $\mathrm{p}>0.05$ ) but was significantly greater at $25^{\circ} \mathrm{C}-30^{\circ} \mathrm{C}$ than at $5^{\circ} \mathrm{C}$ (oneway ANOVA, post-hoc Tukey HSD, $\mathrm{p}<0.018$ ); There were no significant differences between other comparisons (one-way ANOVA, post-hoc Tukey HSD, p > 0.05). There was no $\mathrm{I}_{\mathrm{c}}$ for temperatures at $32.5^{\circ} \mathrm{C}$ and $35^{\circ} \mathrm{C}$ as the respiration rate exceeded photosynthesis. $\mathrm{I}_{\mathrm{c}}$ was significantly greater at $10^{\circ} \mathrm{C}\left(\mathrm{T}_{8}=3.38, \mathrm{p}=0.01\right)$ and $15^{\circ} \mathrm{C}\left(\mathrm{T}_{6}\right.$ $=3.75, \mathrm{p}=0.01)$ under RTC compared with GTC, while no other significant differences were observed between GTC and RTC treatments (Two sample T-Test > $0.05)$. 


\section{5\% saturation irradiance $\left(\mathbf{I}_{k}\right)$}

$\mathrm{I}_{\mathrm{k}}$ (Fig. 3.3D) was significantly different within GTC (ANOVA, $\mathrm{F}_{6,28}=4.47, \mathrm{P}$ $=0.003$ ) and RTC (ANOVA, $\left.F_{6,28}=12.57, \mathrm{P}<0.001\right)$ treatments. $\mathrm{I}_{\mathrm{k}}$ did not change between $5^{\circ} \mathrm{C}$ and $10^{\circ} \mathrm{C}$ under GTC (Post-hoc Tukey HSD, One-way ANOVA, p > 0.05) but was significantly greater at $15^{\circ} \mathrm{C}-30^{\circ} \mathrm{C}$ than at $5^{\circ} \mathrm{C}-10^{\circ} \mathrm{C}$ (one-way ANOVA, post-hoc Tukey HSD, $\mathrm{p}<0.049$ for all comparisons). A significant difference was also observed between $15^{\circ} \mathrm{C}$ and $35^{\circ} \mathrm{C}$ (one-way ANOVA, post-hoc Tukey HSD, p = 0.042); there were no significant differences between other comparisons (one-way ANOVA, Post-hoc Tukey HSD, p > 0.05). Under RTC, $\mathrm{I}_{\mathrm{k}}$ increased significantly between $5^{\circ} \mathrm{C}$ and $10^{\circ} \mathrm{C}-30^{\circ} \mathrm{C}$ (one-way ANOVA, post-hoc Tukey HSD, p < 0.047), while the values at $32.5^{\circ} \mathrm{C}$ and $35^{\circ} \mathrm{C}$ were significantly lower than the values at $10^{\circ} \mathrm{C}$ $25^{\circ} \mathrm{C}$ (one-way ANOVA, post-hoc Tukey HSD, $\mathrm{p}<0.021$ ). $\mathrm{I}_{\mathrm{k}}$ was significantly greater when temperature was increased gradually to $35^{\circ} \mathrm{C}$ than when it was changed rapidly to this temperature $\left(\mathrm{T}_{8}=6.03, \mathrm{p}<0.001\right)$; no other significant differences were evident between $\mathrm{I}_{\mathrm{k}}$ values under GTC and RTC treatments.

\section{Cell specific $\mathbf{P}_{\text {max }}$ gross}

When $\mathrm{P}_{\max }$ gross was normalised to algal density (Fig. 3.3E) significant differences were observed for GTC (ANOVA, $\mathrm{F}_{6,28}=23.75, \mathrm{p}<0.001$ ) and RTC (ANOVA, $\mathrm{F}_{6,28}=8.9, \mathrm{p}=<0.001$ ). Cell specific $\mathrm{P}_{\max }$ gross did not change between $5^{\circ} \mathrm{C}$ and $15^{\circ} \mathrm{C}$ (one-way ANOVA, post-hoc Tukey HSD, p > 0.05), but increased significantly between 5 and $10^{\circ} \mathrm{C}$, and $25^{\circ} \mathrm{C}$ and $35^{\circ} \mathrm{C}$ (one-way ANOVA, post-hoc Tukey HSD, $\mathrm{p}<0.037)$. Cell specific $\mathrm{P}_{\max }$ gross peaked at $32.5^{\circ} \mathrm{C}$ before decreasing significantly by 2.3 times at $35^{\circ} \mathrm{C}$ (one-way ANOVA, post-hoc Tukey HSD, p < 0.001). Under RTC, cell specific $\mathrm{P}_{\max }$ gross did not vary over $5^{\circ} \mathrm{C}-25^{\circ} \mathrm{C}$ (one-way ANOVA, post-hoc Tukey HSD, $\mathrm{p}>0.05$ ) but was significantly greater at $30^{\circ} \mathrm{C}-35^{\circ} \mathrm{C}$ than at $5^{\circ} \mathrm{C}$ (one-way ANOVA, post-hoc Tukey HSD, p < 0.022). Furthermore, the maximum cell 
specific $\mathrm{P}_{\max }$ gross at $35^{\circ} \mathrm{C}$ was significantly greater than rates at $10^{\circ} \mathrm{C}-25^{\circ} \mathrm{C}$ (one-way ANOVA, post-hoc Tukey HSD, $\mathrm{p}<0.039)$. Rates of cell specific $\mathrm{P}_{\max }$ gross under RTC treatments of $30^{\circ} \mathrm{C}\left(\mathrm{T}_{9}=2.32, \mathrm{p}=0.045\right)$ and $35^{\circ} \mathrm{C}\left(\mathrm{T}_{8}=2.33, \mathrm{p}=0.048\right)$ were significantly greater than at corresponding temperatures under GTC; no other significant differences were evident between GTC and RTC treatments Two sample TTest $>0.05)$.

\section{$\mathbf{P}_{\max }$ gross}

Significant differences were observed in rates of $\mathrm{P}_{\max }$ gross (Fig. 3.3F) for GTC $\left(\right.$ ANOVA, $\left.\mathrm{F}_{6,28}=24.86, \mathrm{p}<0.001\right)$ and RTC (ANOVA, $\left.\mathrm{F}_{6,28}=24.51, \mathrm{P}<0.001\right)$ treatments. Rates of $\mathrm{P}_{\max }$ gross under GTC did not vary between $5^{\circ} \mathrm{C}$ and $10^{\circ} \mathrm{C}$ (oneway ANOVA, post-hoc Tukey HSD, p >0.05), but increased significantly at $15^{\circ} \mathrm{C}-$ $35^{\circ} \mathrm{C}$ (one-way ANOVA, post-hoc Tukey HSD, $\mathrm{p}<0.02$ for all comparisons with $5^{\circ} \mathrm{C}$ ). The rate of $\mathrm{P}_{\max }$ gross was greatest at $32.5^{\circ} \mathrm{C}$ and decreased by 2.3 times at $35^{\circ} \mathrm{C}$, when it was significantly lower than at $25^{\circ} \mathrm{C}-32.5^{\circ} \mathrm{C}$ (one-way ANOVA, Post-hoc Tukey HSD, $\mathrm{p}<0.02$ ). Similarly, under RTC rates of $\mathrm{P}_{\max }$ gross did not vary between $5^{\circ} \mathrm{C}$ and (one-way ANOVA, post-hoc Tukey HSD, p > 0.05) and increased significantly between $10^{\circ} \mathrm{C}$ and $15^{\circ} \mathrm{C}-35^{\circ} \mathrm{C}$ (one-way ANOVA, Post-hoc Tukey HSD, p < 0.012). Furthermore, $\mathrm{P}_{\max }$ gross at $30^{\circ} \mathrm{C}$ and $32.5^{\circ} \mathrm{C}$ was significantly greater than at $10^{\circ} \mathrm{C}$ and $15^{\circ} \mathrm{C}$ (one-way ANOVA, Post-hoc Tukey HSD, $\mathrm{p}<0.014$ ), while $\mathrm{P}_{\max }$ gross was significantly greater at $35^{\circ} \mathrm{C}$ compared with $10^{\circ} \mathrm{C}-15^{\circ} \mathrm{C}$. Rates of $\mathrm{P}_{\max }$ gross under RTC treatments were significantly greater than those under GTC treatments at both $10^{\circ} \mathrm{C}\left(\mathrm{T}_{8}=3.46, \mathrm{p}=0.009\right)$ and $35^{\circ} \mathrm{C}\left(\mathrm{T}_{8}=4.22, \mathrm{p}=0.003\right)$, though not at the other temperatures (Two sample T-test > 0.05). 


\section{Control temperature P-I curves}

Control P - I curves are displayed in Appendix C, Fig. 5.3. None of the photosynthetic parameters changed over time under control treatments [ $\alpha$ (ANOVA, $F_{4}$, $10=1.51, \mathrm{P}=0.271), \mathrm{P}_{\max }$ gross $\left(\right.$ ANOVA, $\left.\mathrm{F}_{4,10}=2.51, \mathrm{P}=0.108\right)$, cell specific $\mathrm{P}_{\max } \operatorname{gross}\left(\right.$ ANOVA, $\left.\mathrm{F}_{4,10}=1.19, \mathrm{p}=0.371\right), \mathrm{I}_{\mathrm{k}}\left(\right.$ ANOVA, $\left.\mathrm{F}_{4,10}=1.78, \mathrm{P}=0.209\right), \mathrm{I}_{\mathrm{c}}$ (ANOVA, $\mathrm{F}_{4,10}=1.76, \mathrm{P}=0.213$ ), respiration $\left.\left(\mathrm{ANOVA}, \mathrm{F}_{4,10}=1.14, \mathrm{P}=0.391\right)\right]$ 

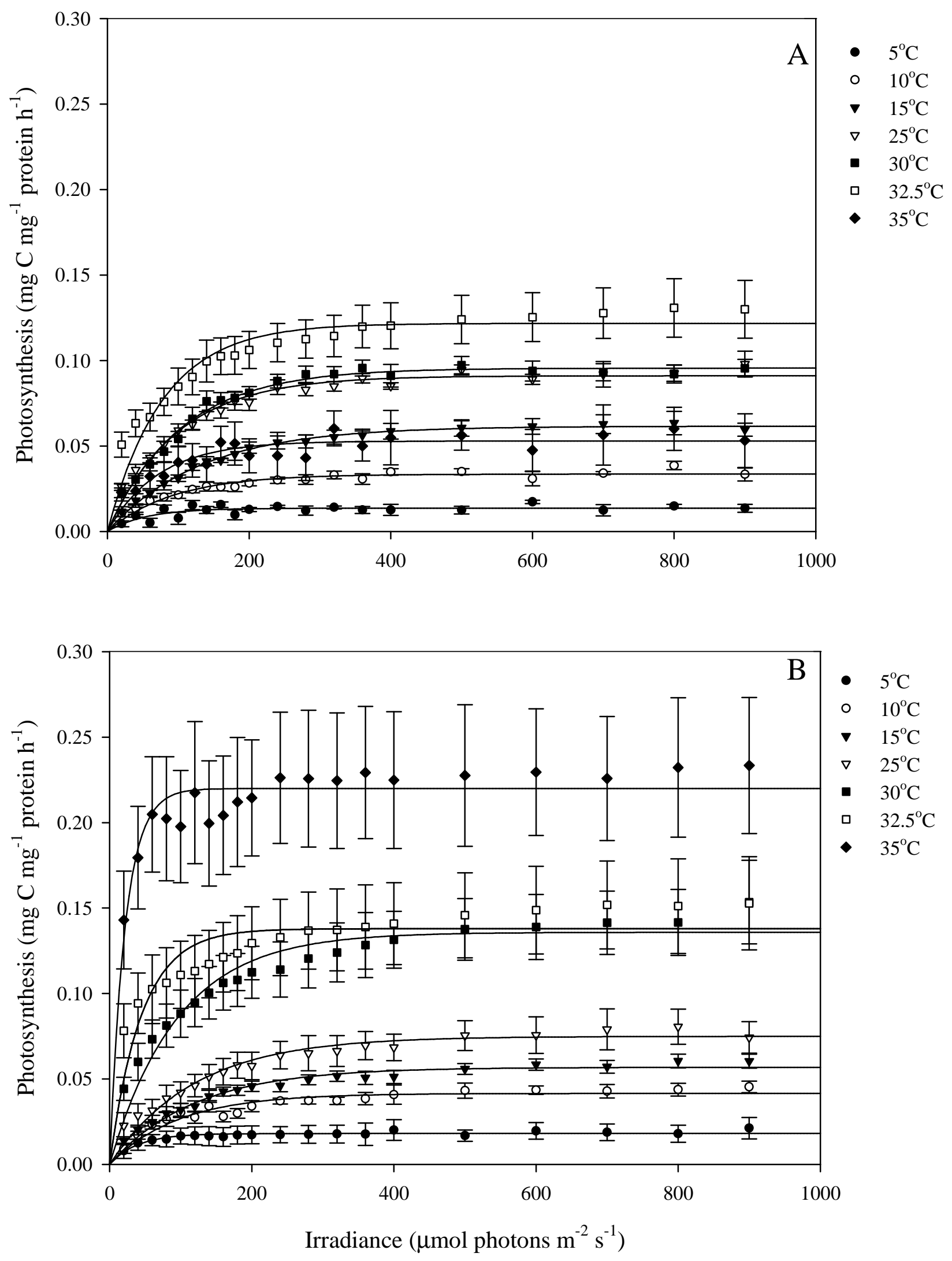

Figure 3.2. Photosynthesis vs. irradiance curves for Anthoplerua aureoradiata subjected to different temperatures. (A) Gradual temperature change $(\mathrm{n}=5$ for all, except $\mathrm{n}=6$ for $30^{\circ} \mathrm{C}$ and $\mathrm{n}=4$ for $\left.25^{\circ} \mathrm{C}\right)$. (B) Rapid temperature change $(\mathrm{n}=5)$; values are mean $\pm 1 \mathrm{SE}$. 

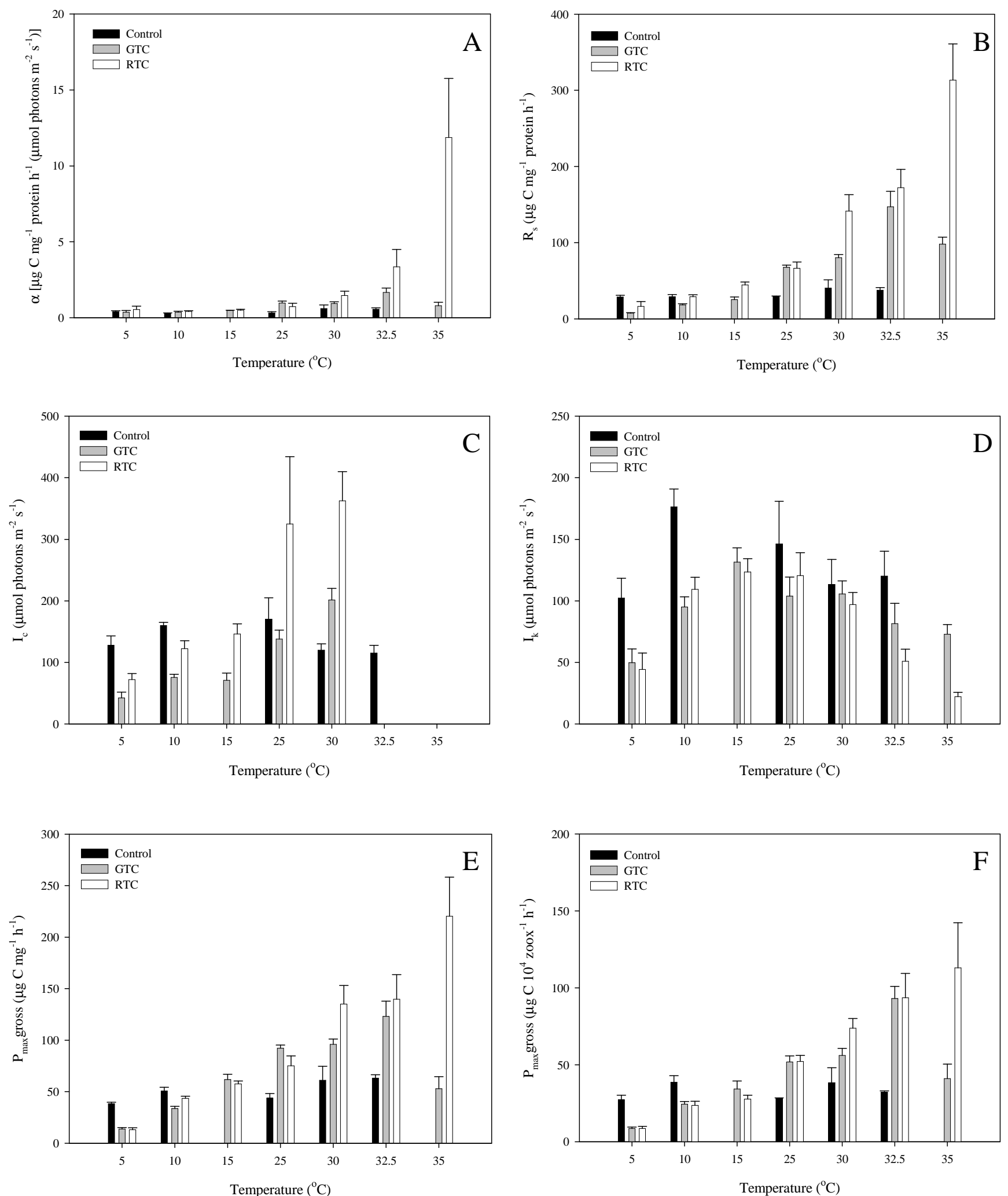

Figure 3.3. Photosynthesis - irradiance parameters for Anthopleura aueroradiata subjected to different temperatures. (A) Initial slope of $\mathrm{P}-\mathrm{I}$ curve $(\alpha)$. (B) Dark respiration rate of intact symbiosis. $(\boldsymbol{C})$ Compensation irradiance $\left(\mathrm{I}_{\mathrm{c}}\right)$. (D) $95 \%$ saturation irradiance $\left(\mathrm{I}_{\mathrm{k}}\right)$. (E) Cell specific $\mathrm{P}_{\max }$ gross.. $(\boldsymbol{F})$ Maximum rate of photosynthesis ( $\mathrm{P}_{\max }$ gross); $(\mathrm{n}=5$ for all $\mathrm{GTC}$ and $\mathrm{RTC}$ except $\mathrm{n}=$ 4 for $25^{\circ} \mathrm{C}$ and $\mathrm{n}=6$ for $30^{\circ} \mathrm{C}$ under GTC) ( $=3$ for control treatments and $25^{\circ} \mathrm{C}$ and $30^{\circ} \mathrm{C}$ for $\mathrm{I}_{\mathrm{c}}$ under RTC); values are mean $\pm 1 \mathrm{SE}$. 


\subsubsection{Carbon and cell specific growth rates and carbon translocation}

Parameters used in the estimation of the CZAR, for GTC and RTC treatments are shown in Tables 3.3 - 3.4. (Parameters used in the estimation of CZAR and CZAR values for control treatments are shown in Appendix C, Table 5.10). Net rates of zooxanthellar photosynthesis $\left(\mathrm{P}_{\mathrm{z}}\right.$ net) were greatest at $15^{\circ} \mathrm{C}\left(361.7 \mu \mathrm{g} \mathrm{C} \mathrm{mg}^{-1}\right.$ protein $\left.\mathrm{d}^{-1}\right)$ under GTC and $10^{\circ} \mathrm{C}\left(1027 \mu \mathrm{g} \mathrm{C} \mathrm{mg}^{-1}\right.$ protein $\left.\mathrm{d}^{-1}\right)$ under RTC. A greater $\mathrm{P}_{\mathrm{z}}$ net resulted in a greater predicted carbon specific growth rate $\left(\mu_{\mathrm{c}}\right)$ at $15^{\circ} \mathrm{C}\left(0.223 \mathrm{~d}^{-1}\right)(\mathrm{GTC})$ and $10^{\circ} \mathrm{C}\left(0.07 \mathrm{~d}^{-1}\right)$ (RTC) than at other temperatures.

Rates of translocation under GTC increased from $33 \%$ at $5^{\circ} \mathrm{C}$ to $88 \%$ at $25^{\circ} \mathrm{C}$. In contrast, translocation under RTC only occurred at $10^{\circ} \mathrm{C}(69 \%)$, as more carbon was required for algal growth at the other temperatures than was fixed in photosynthesis.

Rates of animal respiration $\left(\mathrm{R}_{\mathrm{a}}\right)$ increased with temperature across both treatments. For example $\mathrm{R}_{\mathrm{a}}$ under GTC increased between $5^{\circ} \mathrm{C}$ and $32.5^{\circ} \mathrm{C}$ before decreasing at $35^{\circ} \mathrm{C}$. In comparison $\mathrm{R}_{\mathrm{a}}$ under $\mathrm{RTC}$ increased from $5^{\circ} \mathrm{C}$ to a peak at $35^{\circ} \mathrm{C}$. 
Table 3.3. Parameters used in the estimation of CZAR for Anthopleura aureoradiata at different temperature treatments under gradual temperature change. $(\mu=$ cell specific growth rate; $\mathrm{P}_{\mathrm{z}}=$ predicted net photosynthesis by zooxanthellae; $\mu_{\mathrm{c}}=$ carbon specific growth rate; $\mathrm{T}=$ percentage of net fixed carbon translocated to host; $\mathrm{R}_{\mathrm{a}}=$ predicted animal respiration per day).

\begin{tabular}{c|ccccccc}
\hline Parameter & $5^{\circ} \mathrm{C}$ & $10^{\circ} \mathrm{C}$ & $15^{\circ} \mathrm{C}$ & $25^{\circ} \mathrm{C}$ & $30^{\circ} \mathrm{C}$ & $32.5^{\circ} \mathrm{C}$ & $35^{\circ} \mathrm{C}$ \\
\hline$\mu\left(\mathrm{d}^{-1}\right)$ & 0.026 & 0.022 & 0.033 & 0.015 & 0.033 & 0.047 & 0.047 \\
$\begin{array}{c}\mathrm{P}_{z} \text { net } \\
(\mu \mathrm{g} \mathrm{C} \mathrm{mg} \mathrm{protein} \mathrm{d}\end{array}$ & 54.7 & 156.7 & 361.7 & 164.3 & 32.3 & 0 & 0 \\
$\mu_{\mathrm{c}}\left(\mathrm{d}^{-1}\right)$ & 0.039 & 0.123 & 0.223 & 0.121 & 0.023 & 0 & 0 \\
$\mathrm{~T}(\%)$ & 0.33 & 0.82 & 0.85 & 0.88 & 0 & 0 & 0 \\
$\begin{array}{c}\mathrm{R}_{\mathrm{a}} \\
\left(\mu \mathrm{g} \mathrm{C} \mathrm{mg} \mathrm{protein} \mathrm{d}^{-1}\right)\end{array}$ & 75.6 & 193.44 & 240.24 & 682.8 & 810.72 & 1697.28 & 1084.08 \\
\hline
\end{tabular}

Table 3.4. Parameters used in the estimation of CZAR for Anthopleura aureoradiata at different temperature treatments under rapid temperature change. $(\mu=$ cell specific growth rate; $\mathrm{P}_{\mathrm{z}}=$ predicted net photosynthesis by zooxanthellae; $\mu_{\mathrm{c}}=$ carbon specific growth rate; $\mathrm{T}=$ percentage of net fixed carbon translocated to host; $\mathrm{R}_{\mathrm{a}}=$ predicted animal respiration per day).

\begin{tabular}{c|ccccccc}
\hline Parameter & $5^{\circ} \mathrm{C}$ & $10^{\circ} \mathrm{C}$ & $15^{\circ} \mathrm{C}$ & $25^{\circ} \mathrm{C}$ & $30^{\circ} \mathrm{C}$ & $32.5^{\circ} \mathrm{C}$ & $35^{\circ} \mathrm{C}$ \\
\hline$\mu\left(\mathrm{d}^{-1}\right)$ & 0.03 & 0.022 & 0.03 & 0.026 & 0.037 & 0.05 & 0.047 \\
$\begin{array}{c}\mathrm{P}_{z} \text { net } \\
\left(\mu \mathrm{g} \mathrm{C} \mathrm{mg}{ }^{-1} \text { protein } \mathrm{d}^{-1}\right)\end{array}$ & 0 & 102 & 0 & 22.44 & 0 & 0 & 0 \\
$\mu_{\mathrm{c}}\left(\mathrm{d}^{-1}\right)$ & 0 & 0.07 & 0 & 0.018 & 0 & 0 & 0 \\
$\mathrm{~T}^{(\%)}$ & 0 & 0.69 & 0 & 0 & 0 & 0 & 0 \\
$\begin{array}{c}\mathrm{R}_{\mathrm{a}} \\
\left(\mu \mathrm{g} \mathrm{C} \mathrm{mg} \text { protein d }^{-1}\right)\end{array}$ & 162.24 & 280.56 & 364.08 & 717.36 & 1392.43 & 1736.88 & 2782.8 \\
\hline
\end{tabular}




\subsubsection{Daily CZAR}

The contribution of translocated carbon to the daily respiratory carbon requirements of the anemone (CZAR), under GTC and RTC, is shown in Fig. 3.4. The CZAR under GTC increased from $23.9 \%$ at $5^{\circ} \mathrm{C}$ to $128 \%$ at $15^{\circ} \mathrm{C}$, before decreasing to $21.2 \%$ at $25^{\circ} \mathrm{C}$ and then zero at $\geq 30^{\circ} \mathrm{C}$. In comparison, the CZAR under RTC was zero except at $10^{\circ} \mathrm{C}$ when it was $25.1 \%$.

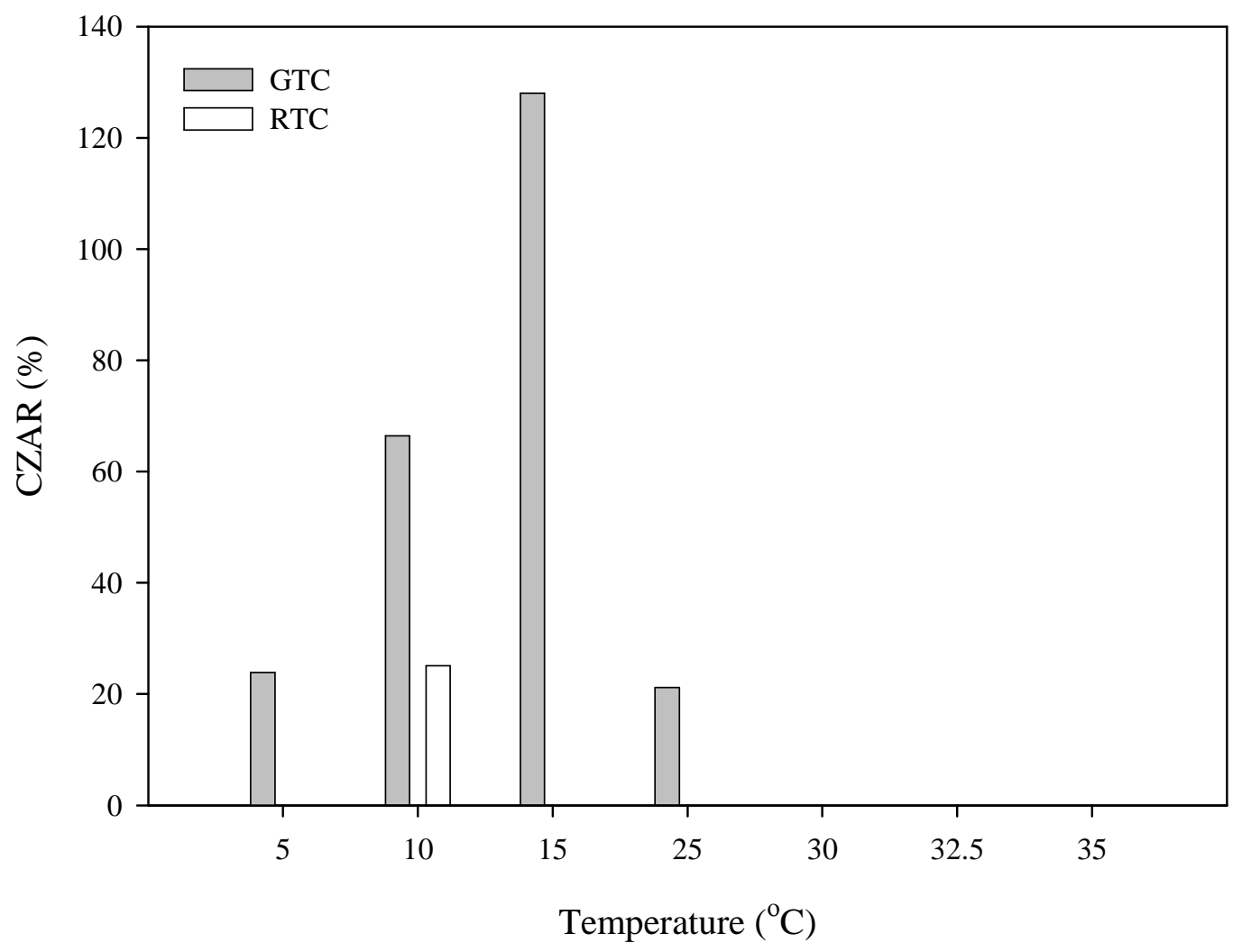

Figure 3.4. Daily CZAR for Anthopleura aureoradiata for gradual and rapid temperature change; no bar represents a CZAR of zero. Values derived from average parameters $(\mathrm{n}=$ 5 under GTC and RTC, except $n=4$ for $15^{\circ} \mathrm{C}$ and $n=6$ for $30^{\circ} \mathrm{C}$ ), hence no error bars are shown. 


\subsection{Discussion}

Both gradual (GTC) and rapid temperature changes (RTC) had no effect on the algal density of Anthopleura aureoradiata. In contrast, the mitotic index (MI) was greater under GTC of $32.5^{\circ} \mathrm{C}$ and $35^{\circ} \mathrm{C}$ compared with $10^{\circ} \mathrm{C}$ and $25^{\circ} \mathrm{C}$ and also greater under RTC at $32.5^{\circ} \mathrm{C}$ and $35^{\circ} \mathrm{C}$ compared with $10^{\circ} \mathrm{C}$. Under GTC and RTC, the photosynthetic parameters of $\alpha, I_{c}$, cell specific $P_{\max }$ gross $P_{\max }$ gross, and respiration increased with temperature, however under GTC these photosynthetic parameters peaked at $32.5^{\circ} \mathrm{C}$ before decreasing at $35^{\circ} \mathrm{C} . \mathrm{I}_{\mathrm{k}}$ under both GTC and RTC treatments increased from $5^{\circ} \mathrm{C}$ $15^{\circ} \mathrm{C}$ before continually decreasing to $35^{\circ} \mathrm{C}$. CZAR measurements were determined to be $<100 \%$ for all temperatures other than the control of $15^{\circ} \mathrm{C}$ when the CZAR was $128 \%$. The highest CZAR measurement under RTC was $25 \%$ at $10^{\circ} \mathrm{C}$, with all other temperatures including the $15^{\circ} \mathrm{C}$ control registering a CZAR of zero.

\subsubsection{Algal density and cell growth}

\subsubsection{Algal density}

Elevated temperatures result in the expulsion of zooxanthellae in a wide range of hosts (Hoegh-Guldberg and Smith 1989a; Brown and Suharsono 1990; Muscatine et al. 1991; Glynn 1993). This may result in zooxanthellae being released by five possible mechanisms: (1) exocytosis, whereby the release of isolated algae occurs (Steen and Muscatine 1987); (2) apoptosis (programmed cell death) (Dunn et al. 2004); (3) cell necrosis, resulting in the release of zooxanthellae associated with host cell tissue (Searle et al. 1982); (4) pinching of the distal portion of the host cell, resulting in the release of 
zooxanthellae surrounded by the vacuolar and pinched off plasma membrane (Glider 1983 cited in Gates et al. 1983); and (5) detachment of endoderm cells from the host and release of these intact cells containing their complement of zooxanthellae (Gates et al. 1992).

However, this study found that GTC and RTC had no effect on algal density. Likewise, studies investigating the effects of temperature on the temperate $A$. elegantissima have found that temperature has no effect (Engebretson and Muller-Parker 1999; Verde and McCloskey 2001). In contrast, Muscatine et al. (1991) showed that when the tropical sea anemones Aiptasia pulchella and A. pallida were exposed briefly to subnormal temperatures (i.e. cold shocked) and then re-warmed to ambient temperatures, they expelled substantial numbers of zooxanthellae. Additionally, Steen and Muscatine (1987) also studying A. pulchella, showed that a brief exposure to low temperature increased the rate of loss of zooxanthellae slightly at $14^{\circ} \mathrm{C}$ but four-fold at $4^{\circ} \mathrm{C}$. The fact that no difference was observed in the algal density of $A$. aureoradiata documents the robustness of this species to the temperatures and length of exposure experienced, reflecting the relative resistance of the zooxanthellae to thermal stress. However, laboratory studies focusing on tropical corals have shown that the length of time needed for cnidarians to expel algae is correlated to the extent to which the temperature is above optimum (Coles and Jokiel 1978; Hoegh-Guldberg and Smith 1989a; Glynn and D'Croz 1990; Dunn et al. 2004; Strychar et al. 2005). This suggests that, for significant differences to be observed in algal density within A. aureoradiata, a longer period of exposure might be needed. 


\subsubsection{Mitotic index}

The trend of elevated MI at higher temperatures seen in A. aureoradiata is consistent with the findings of Steen and Muscatine (1987), who showed that zooxanthellae from Aiptasia pulchella display a decreased MI when exposed to $4^{\circ} \mathrm{C}$ compared with $25^{\circ} \mathrm{C}$ and $14^{\circ} \mathrm{C}$. Furthermore, Verde and McCloskey (2007) suggested that low winter temperatures $\left(8^{\circ} \mathrm{C}\right)$ reduce algal metabolism suppressing the MI. Similarly, Miller et al. (1992) and Suharsono and Brown (1992) reported that the MI of zooxanthellae from heat shocked Anemonia viridis was higher than from unstressed anemones. However, the trend observed in this study should be treated with caution, as sampling of the MI was conducted only once over the course of a day at each temperature, and so natural variation could account for the differences seen (even though the division cycle was asynchronous). In particular, it is somewhat surprising that differences were seen in the RTC treatments given the notoriously slow growth of zooxanthellae and hence low likelihood that the growth of these algae would have had time to respond to the thermal regime. Verde and McCloskey (2001) observed no significant differences in the MI of zooxanthellae in A. elegantissima exposed to temperatures of $6^{\circ} \mathrm{C}, 12^{\circ} \mathrm{C}, 18^{\circ} \mathrm{C}$ and $24^{\circ} \mathrm{C}$, but suggested that if longer thermal treatments had been applied to their anemones then the MI might have differed. 


\subsubsection{Photophysiology}

\subsubsection{How does the photophysiology and respiration of A. aureoradiata respond to temperature variations?}

Photosynthesis shows either a linear or exponential increase in response to temperature (Eckert et al. 1988). This is because many associated aspects of photosynthesis (e.g. the electron transport chain) are temperature dependent (Oquist 1983; Raven and Geider 1988) causing photosynthesis to increase progressively until an optimum temperature, beyond which it declines rapidly (Davison 1991). This was certainly the case under GTC where the photosynthetic parameters of $\alpha, \mathrm{P}_{\max }$ gross and cell specific all increased from $5^{\circ} \mathrm{C}-32.5^{\circ} \mathrm{C}$ before decreasing at $35^{\circ} \mathrm{C}$, suggesting possible photoinhibition at this temperature, while the respiration rate also followed this trend. In comparison, under RTC these same parameters all increased from $5^{\circ} \mathrm{C}-35^{\circ} \mathrm{C}$. The damaging effects of high temperature are time dependent (Cossins and Bowler 1987 in Fitt et al. 2001; Saxby et al. 2003), which likely explains the different responses to GTC and RTC at $35^{\circ} \mathrm{C}$. $\mathrm{I}_{\mathrm{k}}$ in contrast, peaked at $15^{\circ} \mathrm{C}$ under both GTC and RTC with saturation irradiance being reached at lower irradiances with increases in temperature beyond $15^{\circ} \mathrm{C}$.

Many studies document the temperature at which tropical corals are susceptible to the onset of bleaching; with initial impairment of the photosynthetic apparatus at $32^{\circ} \mathrm{C}-$ $36^{\circ} \mathrm{C}$ (e.g. Iglesias-Prieto et al. 1992; Fitt and Warner 1995; Warner et al. 1996; 1999). This is around the same temperature at which reduced photosynthetic capacity is observed in A. aureoradiata under GTC treatment $\left(35^{\circ} \mathrm{C}\right)$. Similarly, cold temperatures are a problem for tropical corals, as the formation of hermatypic corals declines below $18^{\circ} \mathrm{C}$ (Hoegh-Guldberg 1999). Saxby et al. (2003) demonstrated that Montipora digitata exposed to water temperatures of $12^{\circ} \mathrm{C}$ for 12 hours or more led to the complete loss of 
photosynthetic activity within Photosystem II and consequently death of the exposed coral. Additionally, exposure of $M$. digitata to $14^{\circ} \mathrm{C}$ under low light had little effect while under full sunlight the photosynthetic efficiency was reduced and the coral bleached in 24 h. In comparison, A. aureoradiata is able to tolerate much lower temperatures $\left(5^{\circ} \mathrm{C}\right)$ than its tropical counterparts and can tolerate similar temperatures as its Pacific Northwest congener Anthopleura elegantissima $\left(6^{\circ} \mathrm{C}\right)$ (Verde and McCloskey 2001).

Exposure to low, non-freezing temperatures induces genetic, morphological and physiological changes in plants which results in the development of cold hardiness and the acquisition of freezing tolerance (Huner et al. 1993). Algae from different temperature regimes exhibit differences in the kinetic properties of their photosynthetic enzymes (Davison 1991). For example, Descolas-Gros and de Billy (1987) found that maximum substrate affinity (minimum $\mathrm{K}_{\mathrm{m}}$ ) for Rubisco occurred at $4.5^{\circ} \mathrm{C}$ in the Antarctic diatoms Corethron criophilum, Nitzchia kerguelensis and N. turgiduloides compared with $20^{\circ} \mathrm{C}$ in the same enzyme from the temperate diatoms Skeletonema costatum and Phaeodactylum tricornutum. Similar differences in enzyme optima may explain the differences between temperate and tropical zooxanthellae. A further possibility is that temperate zooxanthellae have different membrane properties than do tropical ones, hence making them less susceptible to temperature variations. Tchernov et al. (2004) determined that the critical threshold temperature separating thermally tolerant from sensitive species of zooxanthellae is determined by the saturation of the lipids within thylakoid membranes. For example, a higher concentration of lipid is suggested to enhance the thermal stability of thylakoid membranes. What roles these mechanisms play in the thermal tolerance of $A$. aureoradiata is worthy of investigation. 


\subsubsection{What are the possible causes of photoinhibition in A. aureoradiata?}

Numerous studies show that zooxanthellate cnidarians are highly sensitive to short term increases in temperature which may result in bleaching (Warner et al. 1996; Jones et al. 1998; Fitt et al. 2001; Bhagooli and Hidaka 2004). As shown in this study, A. aureoradiata has a broad photophysiological temperature tolerance under GTC and RTC treatments and displays no change in algal density under these treatments. However, as observed under GTC at $35^{\circ} \mathrm{C}$, a loss of the photophysiological capacity is due to damage of the photosynthetic apparatus, which is a critical step in the thermal bleaching of zooxanthellate cnidarians (Venn et al. 2008).

Several sites are proposed as the initial onset of damage to the photosystem (Fig 3.5). First, Warner et al. (1996) showed a loss of photosynthetic efficiency within PSII in zooxanthellae from the corals Montastrea annularis, Agaricia lamarki, Agaricia agaricites and Siderastrea radians at temperatures from $30^{\circ} \mathrm{C}-36^{\circ} \mathrm{C}$. These anthozoans related this to deterioration of the reaction centre D1 protein, which is essential to the PSII reaction centre as it binds components for charge separation and electron transport. Second, Tchernov et al. (2004) determined that temperatures of $32^{\circ} \mathrm{C}$ in Symbiodinium sp. damaged thylakoid membranes by causing an increase in the rate of electron transport on the acceptor side of PSII and a simultaneous decrease in the maximum quantum yield within the PSII reaction centre. Consequently, this results in uncoupling of electron transport and the loss of adenosine triphosphate (ATP) production, so restricting carbon assimilation. Lastly, Jones et al. (1998), studying zooxanthellae from the coral Stylophora pistillata, suggested that damage to PSII due to elevated temperature $\left(33^{\circ} \mathrm{C}-34^{\circ} \mathrm{C}\right)$ is a secondary effect due to the impairment of the Calvin Cycle. They documented a decrease 
in carboxylation of ribulose 1,5 bisphosphate (RuBP) leading to reduced rates of utilisation of ATP and NADPH from the electron transport chain; this restricted the rate of flow in the electron chain resulting in a build up of excess excitation energy. This results in the formation of highly reactive triplet states of chlorophyll which react with $\mathrm{O}_{2}$ to form singlet oxygen $\left(-\mathrm{O}_{2}\right)$ (Smith et al. 2005). Singlet oxygen is potentially damaging to proteins such as the D1 protein (Asada 1996) and can also react with components in the light harvesting antennae leading to bleaching of pigments (Halliwell 1991 cited in Venn et al. 2008). This model proposed by Jones et al. (1998) is also suggested to result in the photoinhibition of corals in response to decreasing temperature. Decreased temperature reduces the rates at which enzymes are catalysed in the Calvin Cycle, and the subsequent reduction in photosynthetic electron transport combined with continual high light absorption leads to over-reduction of the light reactions.

These models were developed for tropical corals and Symbiodinium species that are highly sensitive to high/low temperatures. In contrast, there have been no attempts to explain the relative thermal stability in temperate cnidarians. It is likely that one or more of these models of photoinhibition interact and result in photoinhibition at high temperatures in A. aureoradiata, but the mechanisms that enable the wide thermal tolerance of A. aureoradiata, and especially the tolerance to low temperatures, need investigation. 


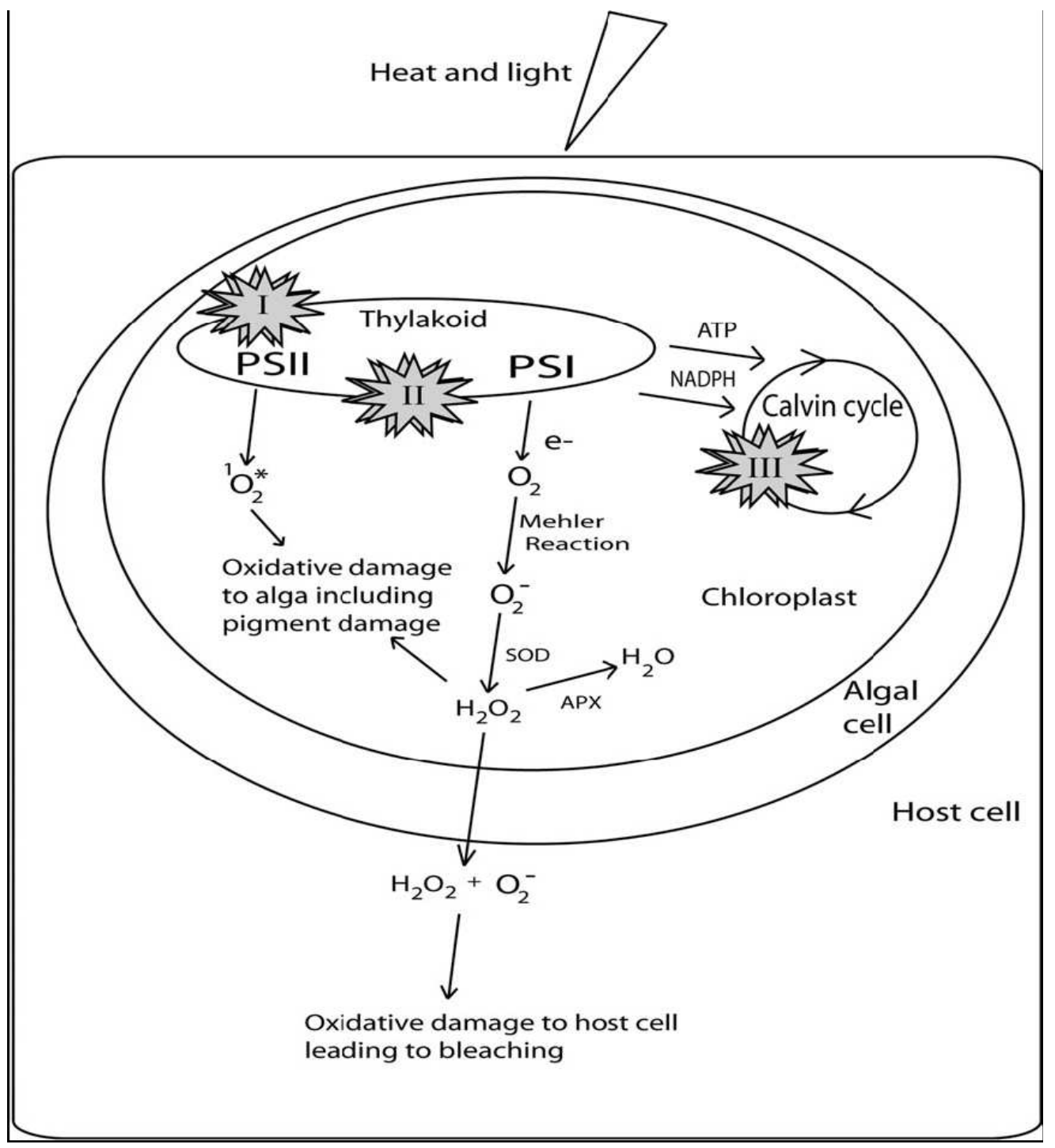

Figure 3.5. Three proposed primary impacts of elevated temperature on the photosystems of symbiotic algae in hosts, shown as I, II, and III in the figure. (I) Dysfunction of PSII and degradation of the D1 protein. (II) Energetic uncoupling in the thylakoid membranes. (III) Impairment of the Calvin cycle. During bleaching ROS are generated from $\mathrm{O}_{2}$ via the Mehler reaction and are detoxified by superoxide dismutase (SOD) and ascorbate peroxidise (APX). If the rate of ROS generation exceeds detoxification, then oxidative damage can occur, triggering signalling pathways and cellular responses that underpin bleaching. Singlet oxygen can be generated at damaged PSII reaction centres and in the photosynthetic antennae causing photobleaching of chlorophyll and accessory pigments. (Venn et al. 2008) 


\subsubsection{CZAR}

\subsubsection{Carbon translocation}

It is commonly thought that up to $95 \%$ of carbon fixed by zooxanthellae is translocated to the animal host for use in basal metabolism (Muscatine et al. 1984). Temperature strongly influences the carbon fixation rate and consequently the metabolic balance between the host and zooxanthellae (Clark and Jensen 1982). Under GTC, estimated rates of carbon translocation increased with increasing temperature from $5^{\circ} \mathrm{C}-25^{\circ} \mathrm{C}$. Engebretson and Muller-Parker (1999) also found increased rates of carbon translocation in A. elegantissima at $20^{\circ} \mathrm{C}$ compared with $13^{\circ} \mathrm{C}$. A high carbon translocation rate results from a lower portion of photosynthetic product being allocated to zooxanthellar growth, so leaving more to be translocated. However, the "growth rate method" of estimating translocation does not account for the surplus photosynthate, if any, that is stored by the zooxanthellae; zooxanthellae have been shown to have substantial carbon stores (MullerParker 1996). To determine translocation rates more accurately it is necessary to know what fraction of the photosynthate is stored and how this value may be influenced by temperature (Muller-Parker and Davy 2001).

In comparison to GTC treatments, when anemones were exposed to RTC treatments carbon translocation could only be measured at $10^{\circ} \mathrm{C}$, when it was $69 \%$. Carbon translocation rates of zero under GTC and RTC treatments reflect the relatively high algal respiration rates at those temperatures, meaning that zooxanthellae cannot fix enough carbon to counter the metabolic carbon demand for both themselves and the host (Verde and McCloskey 2001). Under these conditions, zooxanthellae may therefore be potential carbon parasites on the host (Verde and McCloskey 1996b), exploiting the host 
for protection and nutrient availability (Verde and McCloskey 2001). This topic is further expanded upon in Chapter 4.

\subsubsection{Daily CZAR}

Under GTC, the contribution of zooxanthellae to animal respiration requirements (CZAR) increased by 5.4 times from $5^{\circ} \mathrm{C}(23.9 \%)$ to $15^{\circ} \mathrm{C}(128 \%)$, before declining to $21.2 \%$ at $25^{\circ} \mathrm{C}$ and ultimately zero at $\geq 30^{\circ} \mathrm{C}$. The pattern under RTC was far less clear, with all values being zero except at $10^{\circ} \mathrm{C}(25.1 \%)$. The CZAR should be interpreted with caution as it is not a direct measurement but an extrapolation based on several indirectly obtained values such as carbon translocation and respiration (Musatine et al. 1981).

As with the trend seen under GTC, Verde and McCloskey (2001) documented an increase in CZAR with temperature from $34.9 \%\left(6^{\circ} \mathrm{C}\right)-58.7 \%\left(24^{\circ} \mathrm{C}\right)$ in the temperate $A$. elegantissima. Furthermore, Verde and McCloskey (1996b) reported a CZAR of $49 \%$ for A. elegantissima maintained at a temperature $13^{\circ} \mathrm{C} \pm 1^{\circ} \mathrm{C}$, while Stambler and Dubinsky (1987), calculated a CZAR of $116 \%$ for Mediterranean Anemonia sulcata (= viridis) at a temperature of $22^{\circ} \mathrm{C}$.

In comparison to temperate species, the CZAR measured from tropical zooxanthellate cnidarians is typically $>100 \%$. McCloskey et al. (1994) determined a mean CZAR of $176 \%$ for Mastigias sp. kept at $29^{\circ} \mathrm{C}$, while Day (1994) determined a CZAR of $109 \%$ for Bunodeopsis antilliensis and $92 \%$ for Bunodeopsis globulifera at $28^{\circ} \mathrm{C}$. Further CZAR's are reported for the tropical coral Stylophora pistillata (143\%) (Muscatine et al. 1984) and giant claim Tridana gigas (100\%) (Fisher et al. 1985) at ambient temperature. This suggests that translocated carbon is an important nutritional source for tropical species and perhaps less so for temperate species (Muller-Parker and 
Davy 2001) and highlights the ability of these tropical species to function optimally at temperatures beyond the optimum for A. aureoradiata.

\subsubsection{Ecological implications}

This study has shown that under laboratory conditions, A. aureoradiata has a broad physiological thermal tolerance to temperatures likely experienced in the field, however the capacity to meet the host's carbon demands is compromised at thermal extremes. For instance, under GTC the CZAR only exceed zero at $5-25^{\circ} \mathrm{C}$, the most likely temperature range experienced by $A$. aureoradiata over the course of the year; temperatures of $30-$ $35^{\circ} \mathrm{C}$ ocur occasionally in summer. The highest CZAR occurred at $15^{\circ} \mathrm{C}$ under GTC $(128 \%)$, a similar temperature to that experienced by A. aureoradiata during summer on sunny days at Kau Bay $\left(15.5^{\circ} \mathrm{C}\right)$, and on both sunny and cloudy days at Pauatahanui Inlet $\left(16.5^{\circ} \mathrm{C} / 15.7^{\circ} \mathrm{C}\right)$ (see Chapter 2). This suggests that $\sim 15^{\circ} \mathrm{C}$ is the optimum temperature for complete autotrophy of $A$. aureoradiata and therefore that in the field A. aureoradiata is fully autotrophic in situ in summer, at least when it's not shaded. The temperature of $10^{\circ} \mathrm{C}$ is similar to the temperatures experienced during winter on both sunny and cloudy days at Kau Bay $\left(9.8^{\circ} \mathrm{C} / 9.2^{\circ} \mathrm{C}\right)$ and Pauatahanui Inlet $\left(9.3^{\circ} \mathrm{C} / 8.4^{\circ} \mathrm{C}\right)$ (see Chapter 2 ), however autotrophy could only be partially met at this temperature (66\%). Furthermore, extreme low temperatures of about $5^{\circ} \mathrm{C}$ were recorded at Pauatahanui Inlet in winter. Interestingly, A. aureoradiata could still support nearly $24 \%$ of its metabolic needs through photosynthesis at this temperature, meaning that the anemone may still benefit in some way from the presence of its algal symbionts. Potential benefits of receiving even a small contribution of photosynthate are considered in detail in the next chapter. 


\section{Chapter 4:}

\section{General discussion}

The aim of this thesis was to determine the contribution of algal photosynthetic carbon to animal host respiration (CZAR) in the temperate symbiotic sea anemone Anthopleura aureoradiata. Chapter 2 investigated the effects of cloud cover (sunny vs. cloudy), season (summer vs. winter) and habitat (mud-flat vs. rocky shore), and how these environmental factors influence the photophysiology and consequently the CZAR of $A$. aureoradiata. The CZAR was $>100 \%$ for Kau Bay (rocky shore) during summer on both cloudy and sunny days but $<100 \%$ for all other conditions. Chapter 3 examined the effects of gradual (GTC) and rapid temperature change (RTC) on the photophysiology and subsequently the CZAR of A. aureoradiata. Under GTC, the CZAR increased with temperature and peaked at $128 \%$ at $15^{\circ} \mathrm{C}$ before decreasing and registering a CZAR of zero from $30-35^{\circ} \mathrm{C}$. Under RTC the CZAR was reported at a high of $25.1 \%$ at $10^{\circ} \mathrm{C}$ with all other temperatures reporting a CZAR of zero. Consequently, these results raise two broad questions. First, what are the potential benefits of symbiosis to A. aureoradiata? Second, with the threat of human induced rates of climate change, what is the future for A. aureoradiata?

\subsection{What are the potential benefits of symbiosis to A. aureoradiata?}

Algal-invertebrate symbioses are thought to be mutualistic, as both partners receive benefit from the association via nutritional exchange. This is well documented for 
tropical zooxanthellate cnidarians as, due to a high degree of environmental stability, zooxanthella productivity is much greater in the tropics than in temperate regions leading to more photosynthetic carbon potentially available to tropical hosts (Muller-Parker and Davy 2001). As reported in this study, the daily CZAR determined for A. aureoradiata was only $>100 \%$ on the rocky shore in summer. This raises the possibility that for much of the year, and even in summer, the zooxanthellae may be parasitic on A. aureoradiata, especially on the mudflat.

Zooxanthellae are known to result in costs to their host because they take up space and nutrition. Further costs are associated with horizontal transmission of symbionts. For example, Sachs and Wilcox (2006) investigating the jellyfish Cassiopea xamachana showed a shift from mutualism to parasitism under horizontal transmission. Consequently, symbionts grew faster, attained higher densities and were expelled at a higher rate at a cost to host growth and reproduction compared with vertical transmission; A. aureoradiata broods its young, and consequently passes on symbionts vertically, so the likelihood of parasitism evolving in this symbiosis may be less. Having said that, $A$. aureoradiata contains Symbiodinium Clade A, which Stat et al. (2008) propose as parasitic. Clade A zooxanthellae have been described as fast growing and opportunistic, as they are found in tropical corals recovering from bleaching events (Toller et al. 2001; LaJeunesse 2005). Stat et al. (2008) found that Clade A symbionts do not provide as much carbon to their host as do Clade C symbionts. Similarly here, Clade A zooxanthellae in $A$. aureoradiata frequently did not meet the energy requirements of the host. It is important to note though, that Stat et al. (2008) claim that there is no direct evidence that the interaction between Clade A symbionts and corals is parasitic; rather, Clade A algae may simply be less beneficial to corals than zooxanthellae from other 
lineages. However, despite the suggestion of parasitism, there may still be potential benefits to having a CZAR $<100 \%$ but greater than zero.

One of the benefits of symbiosis to A. aureoradiata is that it may provide a competitive advantage over other species. For example, Anemonia viridis and Anthopleura ballii are shown to occur at higher densities than other macro invertebrates. In Lough Hyne (Eire), A. viridis occurs at a maximum density of 185 per $\mathrm{m}^{2}$, whilst $A$. ballii occurs at a maximum density of 40 per $\mathrm{m}^{2}$. At these densities A. viridis and A. ballii exclude common azooxanthellate anthozoans such as Metridium senile and Corynactis viridis (Turner 1988 cited in Davy et al. 1997). On personal observation A. aureoradiata is found in high abundance within the mudflat and on the rocky shore and may be at just as high or higher densities than other macro-invertebrates. Though A. aureoradiata was reported to be predominantly heterotrophic at Pauatahanui Inlet, the ability to feed autotrophically at certain times of the year and for a large part of the year at Kau Bay may give it a competitive advantage over other species. That is, if carbon requirements are meet by heterotrophy then even a small zooxanthellar contribution may enhance the reproductive output and growth of these anemones (Davy et al. 1997).

Increased carbon translocation may result in increased lipid storage in anemones (Fitt and Pardy 1981; Harland et al. 1992). Harland et al. (1992) showed lipid levels within A. viridis to increase under 10,100 and $300 \mu \mathrm{mol}$ photons $\mathrm{m}^{-2} \mathrm{~s}^{-1}$ over 60 days. The percentage lipid in whole-anemone dry weight increased from $8.87 \%$ at $10 \mu \mathrm{mol}$ photons $\mathrm{m}^{-2} \mathrm{~s}^{-1}$ to $16 \%$ at $300 \mu \mathrm{mol}$ photons $\mathrm{m}^{-2} \mathrm{~s}^{-1}$. This storage of surplus lipid may be vital for A. aureoradiata to divert into reproduction and/or growth. Alternatively, during the winter when the CZAR is zero at certain times, this stored carbon may support basal metabolism. Values of $10-20 \%$ lipid on a dry weight basis have been reported for the 
temperate Anthopleura elegantissima (Jennison 1979; Fitt and Pardy 1981) with this value dropping to $5-8 \%$ immediately after spawning (Jennison 1979).

The benefit of zooxanthellae to A. aureoradiata may not be a nutritional advantage. For instance, zooxanthellae could be distasteful to predators such as the carnivorous whelks Epitonium tenellum and Epitonium jukesianum that prey upon $A$. aureoradiata (Morton 2004). It has been shown that the mosshead sculpin Clinocottus globiceps selectively feeds on the tentacles of A. elegantissima containing zooxanthellae while ignoring those containing zoochlorellae and algal-free anemones (Augustine and Muller-Parker 1998). This is suggested to be due to zooxanthellate anemones having a greater nutritional value, due to the translocation of greater quantities of photosynthetic products to the host, or because zooxanthellae are degraded while zoochlorellae pass through the gut unscathed. Additional factors that influence $C$. globiceps preference may include visual recognition, chemical cues released by the anemones, and taste preference. Whilst this example does not specifically prove the point that zooxanthellae are distasteful to the predator of $A$. aureoradiata, it may suggest that just as zoochlorellae are least preferred by $C$. globiceps, zooxanthellae within A. aureoradiata may covey some particular deterrent to E. tenellum and E. jukesianum.

There may be no potential benefit or disadvantage for $A$. aureoradiata containing zooxanthellae as they may be a residual from another time with no selective pressure for their loss given the abundance of exogenous food in their environment. This may explain why A. aureoradiata is found to inhabit light-limited environments such as cracks and crevices within the rocky shore and lives buried $1-2 \mathrm{~cm}$ under the sediment for long periods of time. Consequently, forming a symbiosis with photosynthetic algae within a light-limited environment may have no real consequence for the host. 
The reduced benefit of zooxanthellae to temperate symbioses in comparison to tropical associations may be one reason for the limited number of temperate algalinvertebrate associations. Other reasons may relate to the temperature tolerance of symbiotic algae (O'Brien and Wyttenbach 1980) or a greater resistance of temperate Cnidaria to infection by algae (Davy et al. 1997). A reduced selective pressure for symbiosis may also explain why temperate hosts receive a smaller proportion of their metabolic carbon requirements from their zooxanthellae than do tropical hosts (Verde and McCloskey 1996a; Davy et al. 1997). Presumably this indicates a lower level of hostsymbiont integration in temperate symbioses than in tropical ones. Consequently, this competitive advantage provided by zooxanthellae may drive the evolution of algalinvertebrate associations in temperate waters, perhaps at a slower rate than occurs in the tropics (Davy et al. 1997). This may steadily increase both the diversity of algalinvertebrate symbioses at temperate latitudes and the degree of host symbiont integration in existing associations.

\subsection{Climate change: what is the future for A. aureoradiata?}

During the past 100 years, increasing $\mathrm{CO}_{2}$ has driven an increase in the global ocean average temperature by $0.74^{\circ} \mathrm{C}$. Global temperatures are predicted to rise $2^{\circ} \mathrm{C}$ by $2050-$ 2100 , values that exceed those of at least the past 420,000 years during which most extant marine organisms evolved (Hoegh-Guldberg et al. 2007). Increases in the temperature of tropical and subtropical waters over the past 50 years have already pushed reef-building corals close to their limits. Prior to this, seawater temperature has always been a degree or two below critical summer levels, suggesting that corals have not been able to 
acclimatize or adapt to these increases (Hoegh-Guldberg 1999). Around New Zealand, the ocean temperature over the past 70 years (at $900 \mathrm{~m}$ ) has been shown to change by only -0.4 to $0.4^{\circ} \mathrm{C}$ (IPCC 2007). The survival of $A$. aureoradiata may therefore be more assured than that of its tropical conterparts, not least because of its wide thermal tolerance. Tropical corals do not appear to have acclimatized to increases in seawater temperature over the past 20 years (Hoegh-Guldberg 1999), long term (>100 years) it may be that $A$. aureoradiata will also struggle to acclimatize to temperature increases. One potential mechanism for corals to survive long term is to change their symbionts for a more thermally-tolerant type. This hypothesis, termed the "adaptive bleaching hypothesis" $(\mathrm{ABH})$, proposes that heat stressed corals expel the current symbionts and take up another variety that are better suited to the prevailing thermal regime (Buddemeier and Fautin 1993). The ABH is limited, as it is not well supported by critical evidence as the observation that corals, when heat stressed, expel one type of zooxanthella and take up another more heat-tolerant type has never been made (HoeghGuldberg 1999). However, Berkelmans and Van Oppen (2006) showed a capacity for the coral Acropora millepora to "shuffle" its co-existing symbionts, with a change in the dominant symbiont type from $\mathrm{C}$ to $\mathrm{D}$. The level of tolerance gained by the corals changing their dominant symbiont to type $\mathrm{D}$ was $1-1.5^{\circ} \mathrm{C}$. However, there appears limited capacity for switching or shuffling of symbionts in A.aureoradiata, as currently the only known symbionts to form an association with this anemone are zooxanthellae belonging to Symbiodinium Clade A and this anemone is currently the only known zooxanthellate host in New Zealand. While the symbiosis between A. aureoradiata and its zooxanthellae may be threatened in the long term, it is important to note that the anemone's survival might be facilitated by the abundance of food in the water column. 
While bleached corals can no longer obtain all the food they need, temperate anemones (as suggested by the CZAR values here) may survive heterotrophically but at lower population densities.

The threat of thermal warming to A. aureoradiata may not be as great as that of ocean acidification. The increase in anthropogenic atmospheric $\mathrm{CO}_{2}$ leads directly to a reduction in the $\mathrm{pH}$ of the ocean and will have profound consequences for ocean ecosystems (Guinotte and Fabry 2008). The threat of ocean acidification appears more of a threat to scleractinian corals than to A. aureoradiata due to the effect on the calcification rate, which is predicted to be reduced by $20-60 \%$ at double pre-industrial $\mathrm{CO}_{2}$ concentrations (560 ppm). The possible effects on the algal symbiont remain unknown, however Hinga (2002) suggests that reduced ocean $\mathrm{pH}$ could impact on phytoplankton through growth rates and abundances. Similar effects on zooxanthellae may well occur and A. aureoradiata could be especially susceptible as colder waters hold more $\mathrm{CO}_{2}$ and are more acidic than warmer waters (Guinotte and Fabry 2008).

\subsection{In Summary}

The symbiosis between $A$. aureoradiata and its zooxanthellae appears to be highly robust to field conditions and the extreme temperatures experienced under laboratory conditions. However, though zooxanthellae residing within A. aureoradiata have a broad thermal tolerance, they may only have a low nutritional value to the host and may even be considered parastitic in the long term. Short term predictions of $0.74^{\circ} \mathrm{C}$ in the next $50-$ 100 years of ocean warming should not pose a threat to A. aureoradiata but additional 
factors such as ocean acidification may pose a greater threat. The potential impact of such stresses and their cumulative effects with warming needs to be determined. 


\section{Chapter 5:}

\section{Appendices}

\subsection{Appendix A}

\section{Contribution of zooxanthellae to animal respiration (CZAR)}

\section{Photosynthetic Parameters}

Muscatine et al. $(1981,1983)$ were referred to for calculations of gross photosynthesis, conversions of oxygen units to carbon units and CZAR equations.

Gross photosynthesis ( $\mathrm{P}($ gross $) ; \mathrm{mg} \mathrm{O}_{2} \mathrm{1}^{-1} \mathrm{~h}^{-1}$ ) at each irradiance was calculated by adding net photosynthesis $(\mathrm{P}($ net $))$ to dark respiration $\left(\mathrm{R}_{\mathrm{s}} ; \mathrm{mg} \mathrm{O}_{2} \mathrm{1}^{-1} \mathrm{~h}^{-1}\right)$ as in Equation 5.1. $\mathrm{P}$ (gross) was converted from oxygen units $\left(\mathrm{mg} \mathrm{O}_{2} 1^{-1} \mathrm{~h}^{-1}\right)$ to carbon units (mg C $1^{-1} h^{1}$ ) as in Equation 5.2 and dark respiration $\left(\mathrm{R}_{\mathrm{s}}\right)$ was converted to carbon units $\left(\mathrm{mg} \mathrm{C} 1^{-1} \mathrm{~h}^{-1}\right)$ as in Equation 5.3.

Equation 5.1:

$$
\mathrm{P}(\text { gross })=\mathrm{P}(\text { net })+\mathrm{R}_{\mathrm{s}}
$$

Equation 5.2: $\mathrm{mg} C$ fixed in photosynthesis $=\left(\mathrm{mg} \mathrm{O}_{2}\right.$ produced $\left.\mathrm{xPQ}\right) \mathrm{x}^{12} / 32$ $\left(\mathrm{PQ}=\right.$ the molecular photosynthetic quotient, $+\mathrm{O}_{2} /-\mathrm{CO}_{2}$, assumed to be 1.1) 
Equation 5.3: $\quad \operatorname{mg} C$ respired $=\left(\mathrm{mg} \mathrm{O}_{2} \text { consumed } \mathrm{x} R\right)^{\mathrm{x}}{ }^{12} / 32$

$\left(\mathrm{RQ}=\right.$ the molecular respiratory quotient, $-\mathrm{O}_{2} /+\mathrm{CO}_{2}$, is assumed to be 0.9$)$

Photosynthetic physiological parameters were derived from the photosynthesis irradiance curve. The initial slope of the P - I curve $(\boldsymbol{\alpha})$ provides an estimate of the photosynthetic efficiency of the zooxanthellae and was calculated by measuring the rate of photosynthesis $\left(\mathrm{mg} \mathrm{C} \mathrm{mg}^{-1}\right.$ protein $\mathrm{h}^{-1}$ ) per $\mu \mathrm{mol}$ photons $\mathrm{m}^{-2} \mathrm{~s}^{-1}$. The maximum photosynthetic rate ( $\mathbf{P}_{\text {max }}$ gross) is a measure of the photosynthetic capacity of zooxanthellae at photosynthetically saturating irradiances. Cell specific $\mathrm{P}_{\max }$ gross measures maximum photosynthesis per zooxanthella cell and was calculated by $\mathbf{P}_{\max }$ gross / algal cell density. The $95 \%$ saturation irradiance $\left(\mathbf{I}_{\mathbf{k}}\right)$ is the lowest irradiance at which light saturated rates of photosynthesis are attained and is derived from the intersection of tangents to $\alpha$ and $\mathrm{P}_{\max }$ gross. The compensation irradiance $\left(\mathbf{I}_{\mathbf{c}}\right)$ is the irradiance at which there is no net oxygen flux and is determined where photosynthesis = respiration.

\section{Zooxanthella Biomass Parameters}

Algal cell diameters $(n=100)$ of zooxanthellae were determined by light microscopy $(x$ 400), whereby 1 graticule division $(\mathrm{gd})=2.5 \mu \mathrm{m}$. The algal cell volume, assuming the cell is a sphere was calculated as in Equation 5.4, where $\pi=3.14$ and $\mathrm{r}^{3}$ is the radius of the cell. Algal cell carbon content $(\mu \mathrm{g})$ was derived from the cell diameter $(\mu \mathrm{m})$ and volume $\left(\mu \mathrm{m}^{3}\right)$ using Strathmann's (1967) equation for dinoflagellates and was calculated as in Equation 5.5, where log volume = algal cell. This was then used in the calculation of the derived algal carbon standing stock (C') (Equation 5.9). Algal cell protein was 
derived from carbon content by assuming a C:N ratio of 6.1:1 (D'Elia et al. 1983) and that algal cell protein is nitrogen $\mathbf{x} 6.25$ (Muscatine et al. 1983); this was ultimately used in the calculation of total algal protein (Equation 5.6).

Equation 5.4: Cell volume $=4 / 3 \times \pi\left(\mathrm{r}^{3}\right)$

Equation 5.5: Algal cell carbon content $=((\log$ volume $) \times 0.866-0.46)$

The total number of algae per anemone was estimated from haemacytometer counts and was used in the calculations of total algal protein (Equation 5.6) and algal density (Equation 5.8). Total symbiosis protein was calculated as in Equation 5.7. The derived algal carbon standing stock $\left(C^{\prime}\right)$ was calculated as in Equation 5.9.

Equation 5.6: Total algal protein $=$ Algal cell protein $x$ Total no. of algae per anemone

Equation 5.7: Total symbiosis protein $=$ Total algal protein + Total animal protein

Equation 5.8: Algal density $=$ Total no. of algae $/$ Total animal protein content

Equation 5.9: Algal carbon standing stock $=$ Algal density $\mathrm{x}$ Algal cell carbon 


\section{Specific Growth Rates of Zooxanthellae and Carbon Translocation}

The carbon specific growth rate $\left(\mu_{\mathrm{c}}\right)$ is an estimate of the amount of carbon assimilated by the algal population each day. The carbon specific growth rate was calculated from Equation 5.10, where $C^{\prime}$ is the standing stock of algal carbon i.e. (C per algal cell) $\mathbf{x}$ (total no. of algae per mg animal protein). The net increment of carbon added per day was equal to the net algal photosynthetic production, which was calculated as in Equation 5.14 The cell specific growth rate $(\mu)$ is an estimate of the amount of carbon used for growth and development of new algal cells each day and was calculated as in Equation 5.11, where $t_{d}=$ duration of cytokinesis over $24 \mathrm{hrs}($ expressed as $11 \mathrm{~h} / 24 \mathrm{~h}=$ $0.4583)$ and is derived from Wilkerson et al (1983). Additionally $\mathrm{f}_{1}=$ the average mitotic index over 24 hrs (i.e. $1.3 \%=0.013$ ).

If the net carbon added daily is used in symbiont growth or otherwise translocated then the percentage of translocated carbon $(\mathrm{T})$ is calculated as in Equation 5.12.

Equation 5.10: Carbon specific growth rate $\left(\mu_{\mathrm{c}}\right)=\underline{\text { Net carbon fixed per day }}$

Equation 5.11: Cell specific growth rate $(\mu)=\underline{1 \times \ln \left(1+f_{1}\right)}$

Equation 5.12: Translocation rate $(T)=\underline{\mu}_{c}-\underline{\mu} \times 100$

$\mu_{\mathrm{c}}$ 


\section{Respiration}

Respiration of whole symbiosis $\left(\mathrm{R}_{\mathrm{s}}\right)$, was measured as dark respiration, while respiration of zooxanthellae $\left(\mathrm{R}_{\mathrm{z}}\right)$, was estimated from the assumption that the ratio of algal to total symbiosis respiration is proportional to the protein biomass (Equation 5.8); it was assumed that respiration occurs over $24 \mathrm{~h}$. Respiration of the animal component $\left(\mathrm{R}_{\mathrm{a}}\right)$ is calculated from Equation 5.13.

Equation 5.13: Animal respiration $\left(\mathrm{R}_{\mathrm{a}}\right)=\mathrm{R}_{\mathrm{S}}-\mathrm{R}_{\mathrm{z}}$

For calculation of net zooxanthellar photosynthesis $\left(\mathrm{P}_{\mathrm{z}}(\mathrm{net})\right)$ and full equation of the daily contribution of zooxanthellae to animal respiration (CZAR), see materials and methods of Chapter 2 and 3. 


\subsection{Appendix B}

\section{Two sample T-tests for environmental treatments relating to photosynthetic parameters}

Table 5.1. Two sample T-tests performed on variables of statistical interest for algal density; values of significance shown in bold.

\begin{tabular}{|c|c|c|c|}
\hline Variables compared & DF & T-Value & P-Value \\
\hline $\begin{array}{c}\text { Kau Bay, summer, sunny } \\
\text { vs. } \\
\text { Kau Bay, summer, cloudy }\end{array}$ & 9 & 1.378 & 0.202 \\
\hline $\begin{array}{l}\text { Kau Bay, summer, sunny } \\
\text { Vs. } \\
\text { Pauatahanui Inlet, summer, sunny }\end{array}$ & 10 & 1.689 & 0.122 \\
\hline $\begin{array}{l}\text { Kau Bay, summer, sunny } \\
\text { Vs. } \\
\text { Kau Bay, winter, sunny }\end{array}$ & 10 & 2.166 & 0.056 \\
\hline $\begin{array}{l}\text { Kau Bay, summer, cloudy } \\
\text { Vs. } \\
\text { Pauatahanui Inlet, summer, cloudy }\end{array}$ & 9 & 0.471 & 0.649 \\
\hline $\begin{array}{l}\text { Kau Bay, summer, cloudy } \\
\text { Vs. } \\
\text { Kau Bay, winter, cloudy }\end{array}$ & 11 & 1.001 & 0.338 \\
\hline $\begin{array}{l}\text { Pauatahanui Inlet, summer, sunny } \\
\text { Vs. } \\
\text { Pauatahanui Inlet, summer, cloudy }\end{array}$ & 10 & 0.858 & 0.411 \\
\hline $\begin{array}{l}\text { Pauatahanui Inlet, summer, sunny } \\
\text { Vs. } \\
\text { Pauatahanui Inlet, winter, sunny }\end{array}$ & 10 & 8.924 & $<0.001$ \\
\hline $\begin{array}{l}\text { Pauatahanui Inlet, summer, cloudy } \\
\text { Vs. } \\
\text { Pauatahanui Inlet, winter, cloudy }\end{array}$ & 9 & 4.367 & 0.002 \\
\hline $\begin{array}{l}\text { Kau Bay, winter, sunny } \\
\text { Vs. } \\
\text { Kau Bay, winter, cloudy }\end{array}$ & 12 & 1.983 & 0.071 \\
\hline $\begin{array}{c}\text { Kau Bay, winter, sunny } \\
\text { Vs. } \\
\text { Pauatahanui Inlet, winter, sunny }\end{array}$ & 10 & 3.793 & 0.004 \\
\hline $\begin{array}{c}\text { Kau Bay, winter, cloudy } \\
\text { Vs. } \\
\text { Pauatahanui Inlet, winter, cloudy }\end{array}$ & 11 & 3.276 & 0.007 \\
\hline $\begin{array}{l}\text { Pauatahanui Inlet, winter, cloudy } \\
\text { Vs. } \\
\text { Pauatahanui Inlet, winter, sunny }\end{array}$ & 9 & 3.411 & 0.008 \\
\hline
\end{tabular}


Table 5.2. Two sample T-tests performed on variables of statistical interest for the mitotic index; values of significance shown in bold.

\begin{tabular}{|c|c|c|c|}
\hline Variables compared & DF & T-Value & P-Value \\
\hline $\begin{array}{l}\text { Kau Bay, summer, sunny } \\
\text { vs. } \\
\text { Kau Bay, summer, cloudy }\end{array}$ & 158 & 3.545 & $<0.001$ \\
\hline $\begin{array}{l}\text { Kau Bay, summer, sunny } \\
\text { Vs. } \\
\text { Pauatahanui Inlet, summer, sunny }\end{array}$ & 158 & 0.824 & 0.411 \\
\hline $\begin{array}{l}\text { Kau Bay, summer, sunny } \\
\text { Vs. } \\
\text { Kau Bay, winter, sunny }\end{array}$ & 138 & 5.137 & $<0.001$ \\
\hline $\begin{array}{l}\text { Kau Bay, summer, cloudy } \\
\text { Vs. } \\
\text { Pauatahanui Inlet, summer, cloudy }\end{array}$ & 158 & 0.86 & 0.391 \\
\hline $\begin{array}{l}\text { Kau Bay, summer, cloudy } \\
\text { Vs. } \\
\text { Kau Bay, winter, cloudy }\end{array}$ & 138 & 2.017 & 0.046 \\
\hline $\begin{array}{l}\text { Pauatahanui Inlet, summer, sunny } \\
\text { Vs. } \\
\text { Pauatahanui Inlet, summer, cloudy }\end{array}$ & 158 & 2.551 & 0.012 \\
\hline $\begin{array}{l}\text { Pauatahanui Inlet, summer, sunny } \\
\text { Vs. } \\
\text { Pauatahanui Inlet, winter, sunny }\end{array}$ & 138 & 3.42 & $<0.001$ \\
\hline $\begin{array}{l}\text { Pauatahanui Inlet, summer, cloudy } \\
\text { Vs. } \\
\text { Pauatahanui Inlet, winter, cloudy }\end{array}$ & 138 & 1.699 & 0.091 \\
\hline $\begin{array}{l}\text { Kau Bay, winter, sunny } \\
\text { Vs. } \\
\text { Kau Bay, winter, cloudy }\end{array}$ & 118 & 0.869 & 0.386 \\
\hline $\begin{array}{c}\text { Kau Bay, winter, sunny } \\
\text { Vs. } \\
\text { Pauatahanui Inlet, winter, sunny }\end{array}$ & 118 & 1.884 & 0.062 \\
\hline $\begin{array}{c}\text { Kau Bay, winter, cloudy } \\
\text { Vs. } \\
\text { Pauatahanui Inlet, winter, cloudy }\end{array}$ & 118 & 1.305 & 0.195 \\
\hline $\begin{array}{l}\text { Pauatahanui Inlet, winter, cloudy } \\
\text { Vs. } \\
\text { Pauatahanui Inlet, winter, sunny }\end{array}$ & 118 & 1.303 & 0.195 \\
\hline
\end{tabular}


Table 5.3. Two sample T-tests performed on variables of statistical interest for $\alpha$; Values of significance shown in bold.

\begin{tabular}{|c|c|c|c|}
\hline Variables compared & DF & T-Value & P-Value \\
\hline $\begin{array}{l}\text { Kau Bay, summer, sunny } \\
\text { vs. } \\
\text { Kau Bay, summer, cloudy }\end{array}$ & 9 & 2.625 & 0.028 \\
\hline $\begin{array}{l}\text { Kau Bay, summer, sunny } \\
\text { Vs. } \\
\text { Pauatahanui Inlet, summer, sunny }\end{array}$ & 10 & 1.797 & 0.103 \\
\hline $\begin{array}{l}\text { Kau Bay, summer, sunny } \\
\text { Vs. } \\
\text { Kau Bay, winter, sunny }\end{array}$ & 10 & 3.619 & 0.005 \\
\hline $\begin{array}{l}\text { Kau Bay, summer, cloudy } \\
\text { Vs. } \\
\text { Pauatahanui Inlet, summer, cloudy }\end{array}$ & 9 & 0.236 & 0.26 \\
\hline $\begin{array}{l}\text { Kau Bay, summer, cloudy } \\
\text { Vs. } \\
\text { Kau Bay, winter, cloudy }\end{array}$ & 11 & 0.071 & 0.945 \\
\hline $\begin{array}{l}\text { Pauatahanui Inlet, summer, sunny } \\
\text { Vs. } \\
\text { Pauatahanui Inlet, summer, cloudy }\end{array}$ & 10 & 2.439 & 0.035 \\
\hline $\begin{array}{l}\text { Pauatahanui Inlet, summer, sunny } \\
\text { Vs. } \\
\text { Pauatahanui Inlet, winter, sunny }\end{array}$ & 10 & 5.327 & $<0.001$ \\
\hline $\begin{array}{l}\text { Pauatahanui Inlet, summer, cloudy } \\
\text { Vs. } \\
\text { Pauatahanui Inlet, winter, cloudy }\end{array}$ & 9 & 2.647 & 0.027 \\
\hline $\begin{array}{l}\text { Kau Bay, winter, sunny } \\
\text { Vs. } \\
\text { Kau Bay, winter, cloudy }\end{array}$ & 12 & 2.455 & 0.03 \\
\hline $\begin{array}{c}\text { Kau Bay, winter, sunny } \\
\text { Vs. } \\
\text { Pauatahanui Inlet, winter, sunny }\end{array}$ & 10 & 4.725 & $<0.001$ \\
\hline $\begin{array}{l}\text { Kau Bay, winter, cloudy } \\
\text { Vs. } \\
\text { Pauatahanui Inlet, winter, cloudy }\end{array}$ & 11 & 4.158 & 0.002 \\
\hline $\begin{array}{l}\text { Pauatahanui Inlet, winter, cloudy } \\
\text { Vs. } \\
\text { Pauatahanui Inlet, winter, sunny }\end{array}$ & 9 & 1.654 & 0.132 \\
\hline
\end{tabular}


Table 5.4. Two sample T-tests performed on variables of statistical interest for respiration rates $\left(\mathrm{R}_{\mathrm{s}}\right)$; values of significance shown in bold.

\begin{tabular}{|c|c|c|c|}
\hline Variables compared & DF & T-Value & P-Value \\
\hline $\begin{array}{l}\text { Kau Bay, summer, sunny } \\
\text { vs. } \\
\text { Kau Bay, summer, cloudy }\end{array}$ & 9 & 2.183 & 0.057 \\
\hline $\begin{array}{l}\text { Kau Bay, summer, sunny } \\
\text { Vs. } \\
\text { Pauatahanui Inlet, summer, sunny }\end{array}$ & 10 & 0.745 & 0.474 \\
\hline $\begin{array}{l}\text { Kau Bay, summer, sunny } \\
\text { Vs. } \\
\text { Kau Bay, winter, sunny }\end{array}$ & 10 & 3.269 & 0.008 \\
\hline $\begin{array}{l}\text { Kau Bay, summer, cloudy } \\
\text { Vs. } \\
\text { Pauatahanui Inlet, summer, cloudy }\end{array}$ & 9 & 3.241 & 0.01 \\
\hline $\begin{array}{l}\text { Kau Bay, summer, cloudy } \\
\text { Vs. } \\
\text { Kau Bay, winter, cloudy }\end{array}$ & 11 & 1.922 & 0.081 \\
\hline $\begin{array}{l}\text { Pauatahanui Inlet, summer, sunny } \\
\text { Vs. } \\
\text { Pauatahanui Inlet, summer, cloudy }\end{array}$ & 10 & 2.484 & 0.032 \\
\hline $\begin{array}{l}\text { Pauatahanui Inlet, summer, sunny } \\
\text { Vs. } \\
\text { Pauatahanui Inlet, winter, sunny }\end{array}$ & 10 & 15.402 & $<0.001$ \\
\hline $\begin{array}{l}\text { Pauatahanui Inlet, summer, cloudy } \\
\text { Vs. } \\
\text { Pauatahanui Inlet, winter, cloudy }\end{array}$ & 9 & 10.006 & $<0.001$ \\
\hline $\begin{array}{l}\text { Kau Bay, winter, sunny } \\
\text { Vs. } \\
\text { Kau Bay, winter, cloudy }\end{array}$ & 12 & 2.018 & 0.067 \\
\hline $\begin{array}{c}\text { Kau Bay, winter, sunny } \\
\text { Vs. } \\
\text { Pauatahanui Inlet, winter, sunny }\end{array}$ & 10 & 5.222 & $<0.001$ \\
\hline $\begin{array}{c}\text { Kau Bay, winter, cloudy } \\
\text { Vs. } \\
\text { Pauatahanui Inlet, winter, cloudy }\end{array}$ & 11 & 4.859 & $<0.001$ \\
\hline $\begin{array}{l}\text { Pauatahanui Inlet, winter, cloudy } \\
\text { Vs. } \\
\text { Pauatahanui Inlet, winter, sunny }\end{array}$ & 9 & 3.289 & 0.009 \\
\hline
\end{tabular}


Table 5.5. Two sample T-tests performed on variables of statistical interest for $\mathrm{I}_{\mathcal{c}}$; values of significance shown in bold.

\begin{tabular}{|c|c|c|c|}
\hline Variables compared & DF & T-Value & P-Value \\
\hline $\begin{array}{l}\text { Kau Bay, summer, sunny } \\
\text { vs. } \\
\text { Kau Bay, summer, cloudy }\end{array}$ & 9 & 0.943 & 0.37 \\
\hline $\begin{array}{l}\text { Kau Bay, summer, sunny } \\
\text { Vs. } \\
\text { Pauatahanui Inlet, summer, sunny }\end{array}$ & 10 & 3.037 & 0.013 \\
\hline $\begin{array}{l}\text { Kau Bay, summer, sunny } \\
\text { Vs. } \\
\text { Kau Bay, winter, sunny }\end{array}$ & 10 & 0.771 & 0.458 \\
\hline $\begin{array}{l}\text { Kau Bay, summer, cloudy } \\
\text { Vs. } \\
\text { Pauatahanui Inlet, summer, cloudy }\end{array}$ & 9 & 4.583 & $<0.001$ \\
\hline $\begin{array}{l}\text { Kau Bay, summer, cloudy } \\
\text { Vs. } \\
\text { Kau Bay, winter, cloudy }\end{array}$ & 11 & 3.212 & 0.008 \\
\hline $\begin{array}{l}\text { Pauatahanui Inlet, summer, sunny } \\
\text { Vs. } \\
\text { Pauatahanui Inlet, summer, cloudy }\end{array}$ & 10 & 1.927 & 0.083 \\
\hline $\begin{array}{l}\text { Pauatahanui Inlet, summer, sunny } \\
\text { Vs. } \\
\text { Pauatahanui Inlet, winter, sunny }\end{array}$ & 10 & 2.572 & 0.028 \\
\hline $\begin{array}{l}\text { Pauatahanui Inlet, summer, cloudy } \\
\text { Vs. } \\
\text { Pauatahanui Inlet, winter, cloudy }\end{array}$ & 9 & 2.883 & 0.018 \\
\hline $\begin{array}{l}\text { Kau Bay, winter, sunny } \\
\text { Vs. } \\
\text { Kau Bay, winter, cloudy }\end{array}$ & 12 & 0.334 & 0.744 \\
\hline $\begin{array}{c}\text { Kau Bay, winter, sunny } \\
\text { Vs. } \\
\text { Pauatahanui Inlet, winter, sunny }\end{array}$ & 10 & 1.29 & 0.226 \\
\hline $\begin{array}{l}\text { Kau Bay, winter, cloudy } \\
\text { Vs. } \\
\text { Pauatahanui Inlet, winter, cloudy }\end{array}$ & 11 & 1.155 & 0.273 \\
\hline $\begin{array}{l}\text { Pauatahanui Inlet, winter, cloudy } \\
\text { Vs. } \\
\text { Pauatahanui Inlet, winter, sunny }\end{array}$ & 9 & 0.076 & 0.941 \\
\hline
\end{tabular}


Table 5.6. Two sample T-tests performed on variables of statistical interest for $I_{k}$; values of significance shown in bold.

\begin{tabular}{|c|c|c|c|}
\hline Variables compared & DF & T-Value & P-Value \\
\hline $\begin{array}{l}\text { Kau Bay, summer, sunny } \\
\text { vs. } \\
\text { Kau Bay, summer, cloudy }\end{array}$ & 9 & 0.419 & 0.685 \\
\hline $\begin{array}{l}\text { Kau Bay, summer, sunny } \\
\text { Vs. } \\
\text { Pauatahanui Inlet, summer, sunny }\end{array}$ & 10 & 0.082 & 0.936 \\
\hline $\begin{array}{l}\text { Kau Bay, summer, sunny } \\
\text { Vs. } \\
\text { Kau Bay, winter, sunny }\end{array}$ & 10 & 0.159 & 0.877 \\
\hline $\begin{array}{l}\text { Kau Bay, summer, cloudy } \\
\text { Vs. } \\
\text { Pauatahanui Inlet, summer, cloudy }\end{array}$ & 9 & 2.254 & 0.051 \\
\hline $\begin{array}{l}\text { Kau Bay, summer, cloudy } \\
\text { Vs. } \\
\text { Kau Bay, winter, cloudy }\end{array}$ & 11 & 0.344 & 0.738 \\
\hline $\begin{array}{l}\text { Pauatahanui Inlet, summer, sunny } \\
\text { Vs. } \\
\text { Pauatahanui Inlet, summer, cloudy }\end{array}$ & 10 & 1.557 & 0.15 \\
\hline $\begin{array}{l}\text { Pauatahanui Inlet, summer, sunny } \\
\text { Vs. } \\
\text { Pauatahanui Inlet, winter, sunny }\end{array}$ & 10 & 1.583 & 0.144 \\
\hline $\begin{array}{l}\text { Pauatahanui Inlet, summer, cloudy } \\
\text { Vs. } \\
\text { Pauatahanui Inlet, winter, cloudy }\end{array}$ & 9 & 0.555 & 0.593 \\
\hline $\begin{array}{l}\text { Kau Bay, winter, sunny } \\
\text { Vs. } \\
\text { Kau Bay, winter, cloudy }\end{array}$ & 12 & 0.0661 & 0.521 \\
\hline $\begin{array}{c}\text { Kau Bay, winter, sunny } \\
\text { Vs. } \\
\text { Pauatahanui Inlet, winter, sunny }\end{array}$ & 10 & 2.101 & 0.062 \\
\hline $\begin{array}{c}\text { Kau Bay, winter, cloudy } \\
\text { Vs. } \\
\text { Pauatahanui Inlet, winter, cloudy }\end{array}$ & 11 & 0.957 & 0.359 \\
\hline $\begin{array}{l}\text { Pauatahanui Inlet, winter, cloudy } \\
\text { Vs. } \\
\text { Pauatahanui Inlet, winter, sunny }\end{array}$ & 9 & 0.579 & 0.577 \\
\hline
\end{tabular}


Table 5.7. Two sample $T$-tests performed on variables of statistical interest for cell specific $\mathrm{P}_{\max }$ gross; values of significance shown in bold.

\begin{tabular}{|c|c|c|c|}
\hline Variables compared & DF & T-Value & P-Value \\
\hline $\begin{array}{l}\text { Kau Bay, summer, sunny } \\
\text { vs. } \\
\text { Kau Bay, summer, cloudy }\end{array}$ & 9 & 4.379 & 0.002 \\
\hline $\begin{array}{l}\text { Kau Bay, summer, sunny } \\
\text { Vs. } \\
\text { Pauatahanui Inlet, summer, sunny }\end{array}$ & 10 & 1.122 & 0.288 \\
\hline $\begin{array}{l}\text { Kau Bay, summer, sunny } \\
\text { Vs. } \\
\text { Kau Bay, winter, sunny }\end{array}$ & 10 & 4.614 & $<0.001$ \\
\hline $\begin{array}{l}\text { Kau Bay, summer, cloudy } \\
\text { Vs. } \\
\text { Pauatahanui Inlet, summer, cloudy }\end{array}$ & 9 & 0.679 & 0.514 \\
\hline $\begin{array}{l}\text { Kau Bay, summer, cloudy } \\
\text { Vs. } \\
\text { Kau Bay, winter, cloudy }\end{array}$ & 11 & 0.764 & 0.461 \\
\hline $\begin{array}{l}\text { Pauatahanui Inlet, summer, sunny } \\
\text { Vs. } \\
\text { Pauatahanui Inlet, summer, cloudy }\end{array}$ & 10 & 1.992 & 0.074 \\
\hline $\begin{array}{l}\text { Pauatahanui Inlet, summer, sunny } \\
\text { Vs. } \\
\text { Pauatahanui Inlet, winter, sunny }\end{array}$ & 10 & 3.233 & 0.009 \\
\hline $\begin{array}{l}\text { Pauatahanui Inlet, summer, cloudy } \\
\text { Vs. } \\
\text { Pauatahanui Inlet, winter, cloudy }\end{array}$ & 9 & 2.191 & 0.056 \\
\hline $\begin{array}{l}\text { Kau Bay, winter, sunny } \\
\text { Vs. } \\
\text { Kau Bay, winter, cloudy }\end{array}$ & 12 & 0.426 & 0.678 \\
\hline $\begin{array}{l}\text { Kau Bay, winter, sunny } \\
\text { Vs. } \\
\text { Pauatahanui Inlet, winter, sunny }\end{array}$ & 10 & 0.085 & 0.934 \\
\hline $\begin{array}{l}\text { Kau Bay, winter, cloudy } \\
\text { Vs. } \\
\text { Pauatahanui Inlet, winter, cloudy }\end{array}$ & 11 & 0.8 & 0.441 \\
\hline $\begin{array}{l}\text { Pauatahanui Inlet, winter, cloudy } \\
\text { Vs. } \\
\text { Pauatahanui Inlet, winter, sunny }\end{array}$ & 9 & 1.524 & 0.162 \\
\hline
\end{tabular}


Table 5.8. Two sample T-tests performed on variables of statistical interest for $P_{\max }$ gross; values of significance shown in bold.

\begin{tabular}{|c|c|c|c|}
\hline Variables compared & DF & T-Value & P-Value \\
\hline $\begin{array}{l}\text { Kau Bay, summer, sunny } \\
\text { vs. } \\
\text { Kau Bay, summer, cloudy }\end{array}$ & 9 & 3.606 & 0.006 \\
\hline $\begin{array}{l}\text { Kau Bay, summer, sunny } \\
\text { Vs. } \\
\text { Pauatahanui Inlet, summer, sunny }\end{array}$ & 10 & 2.451 & 0.034 \\
\hline $\begin{array}{l}\text { Kau Bay, summer, sunny } \\
\text { Vs. } \\
\text { Kau Bay, winter, sunny }\end{array}$ & 10 & 4.994 & $<0.001$ \\
\hline $\begin{array}{l}\text { Kau Bay, summer, cloudy } \\
\text { Vs. } \\
\text { Pauatahanui Inlet, summer, cloudy }\end{array}$ & 9 & 1.564 & 0.152 \\
\hline $\begin{array}{l}\text { Kau Bay, summer, cloudy } \\
\text { Vs. } \\
\text { Kau Bay, winter, cloudy }\end{array}$ & 11 & 0.16 & 0.876 \\
\hline $\begin{array}{l}\text { Pauatahanui Inlet, summer, sunny } \\
\text { Vs. } \\
\text { Pauatahanui Inlet, summer, cloudy }\end{array}$ & 10 & 1.657 & 0.128 \\
\hline $\begin{array}{l}\text { Pauatahanui Inlet, summer, sunny } \\
\text { Vs. } \\
\text { Pauatahanui Inlet, winter, sunny }\end{array}$ & 10 & 8.111 & $<0.001$ \\
\hline $\begin{array}{l}\text { Pauatahanui Inlet, summer, cloudy } \\
\text { Vs. } \\
\text { Pauatahanui Inlet, winter, cloudy }\end{array}$ & 9 & 10.897 & $<0.001$ \\
\hline $\begin{array}{l}\text { Kau Bay, winter, sunny } \\
\text { Vs. } \\
\text { Kau Bay, winter, cloudy }\end{array}$ & 12 & 2.761 & 0.017 \\
\hline $\begin{array}{l}\text { Kau Bay, winter, sunny } \\
\text { Vs. } \\
\text { Pauatahanui Inlet, winter, sunny }\end{array}$ & 10 & 8.042 & $<0.001$ \\
\hline $\begin{array}{l}\text { Kau Bay, winter, cloudy } \\
\text { Vs. } \\
\text { Pauatahanui Inlet, winter, cloudy }\end{array}$ & 11 & 6.001 & $<0.001$ \\
\hline $\begin{array}{l}\text { Pauatahanui Inlet, winter, cloudy } \\
\text { Vs. } \\
\text { Pauatahanui Inlet, winter, sunny }\end{array}$ & 9 & 1.613 & 0.141 \\
\hline
\end{tabular}




\subsection{Appendix C}

Control temperature, algal and symbiosis biomass characteristic, P-I curve, CZAR measurements and daily mitotic index for gradual and rapid temperature change treatments

Table 5.9. Algal and symbiosis biomass characteristics (means $\pm 1 \mathrm{SE}$ ) for Anthoplerua aureoradiata for control temperature treatments. Algal cell diameter, volume, derived algal cell carbon, protein and nitrogen content per cell are all measured from $15^{\circ} \mathrm{C}$ GTC. ( $\mathrm{n}=3$ for all measurements).

\begin{tabular}{|c|c|c|c|c|c|}
\hline Parameter & $\begin{array}{l}15^{\circ} \mathrm{C} \\
\left(5^{\circ} \mathrm{C}\right)\end{array}$ & $\begin{array}{r}15^{\circ} \mathrm{C} \\
\left(10^{\circ} \mathrm{C}\right) \\
\end{array}$ & $\begin{array}{r}15^{\circ} \mathrm{C} \\
\left(25^{\circ} \mathrm{C}\right) \\
\end{array}$ & $\begin{array}{r}15^{\circ} \mathrm{C} \\
\left(30^{\circ} \mathrm{C}\right) \\
\end{array}$ & $\begin{array}{c}15^{\circ} \mathrm{C} \\
\left(32.5 / 35^{\circ} \mathrm{C}\right)\end{array}$ \\
\hline $\begin{array}{l}\text { Total no. of algae per anemone } \\
\qquad\left(\times 10^{6}\right)\end{array}$ & $4.84 \pm 0.13$ & $5.63 \pm 0.33$ & $3.64 \pm 0.48$ & $4.25 \pm 0.55$ & $5.13 \pm 0.42$ \\
\hline $\begin{array}{l}\text { Total animal protein } \\
\qquad(\mu \mathrm{g})\end{array}$ & $342.43 \pm 21.19$ & $308.64 \pm 41.08$ & $231.84 \pm 4.58$ & $266.13 \pm 43.09$ & $261.6 \pm 13.14$ \\
\hline $\begin{array}{c}\text { Algal density } \\
\left(\text { algae } \mu \mathrm{g}^{-1} \text { protein } \times 10^{3}\right)\end{array}$ & $14.26 \pm 1.06$ & $13.42 \pm 1.9$ & $15.64 \pm 1.86$ & $16.12 \pm 0.59$ & $19.6 \pm 1.28$ \\
\hline $\begin{array}{l}\text { Total algal protein } \\
(\mathrm{mg})\end{array}$ & $1.21 \pm 0.09$ & $1.13 \pm 0.16$ & $1.32 \pm 0.16$ & $1.36 \pm 0.09$ & $1.66 \pm 0.11$ \\
\hline Algal: Total protein ratio & $0.55 \pm 0.02$ & $0.53 \pm 0.03$ & $0.57 \pm 0.03$ & $0.58 \pm 0.01$ & $0.62 \pm 0.02$ \\
\hline $\begin{array}{c}\text { Derived algal carbon standing stock } \\
\left(\mathrm{C}^{\prime}\right) \\
\left(\mu \mathrm{g} \mathrm{C} \mu \mathrm{g}^{-1} \text { protein }\right)\end{array}$ & $1.17 \pm 0.09$ & $1.11 \pm 0.16$ & $1.29 \pm 0.15$ & $1.33 \pm 0.05$ & $1.62 \pm 0.11$ \\
\hline
\end{tabular}



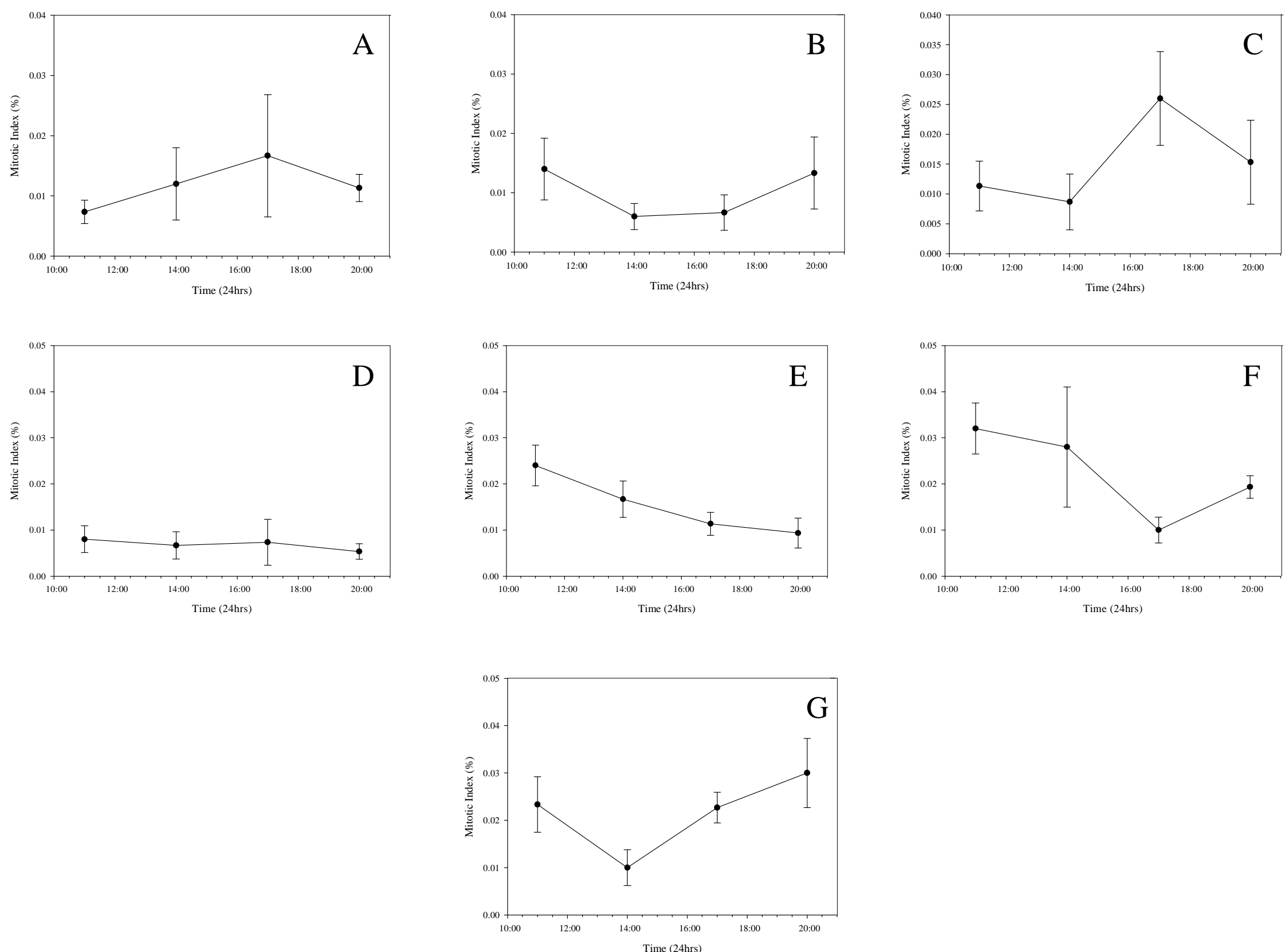

Figure 5.1. Mitotic index for zooxanthellae in Anthopleura aureoradiata under gradual temperature change. $(\boldsymbol{A}) 5^{\circ} \mathrm{C}(\boldsymbol{B}) 10^{\circ} \mathrm{C}$ (C) $15^{\circ} \mathrm{C}(\boldsymbol{D}) 25^{\circ} \mathrm{C}(\boldsymbol{E}) 30^{\circ} \mathrm{C}(\boldsymbol{F}) 32.5^{\circ} \mathrm{C}(\boldsymbol{G}) 32.5^{\circ} \mathrm{C}$; values are means $\pm 1 \mathrm{SE}$. 

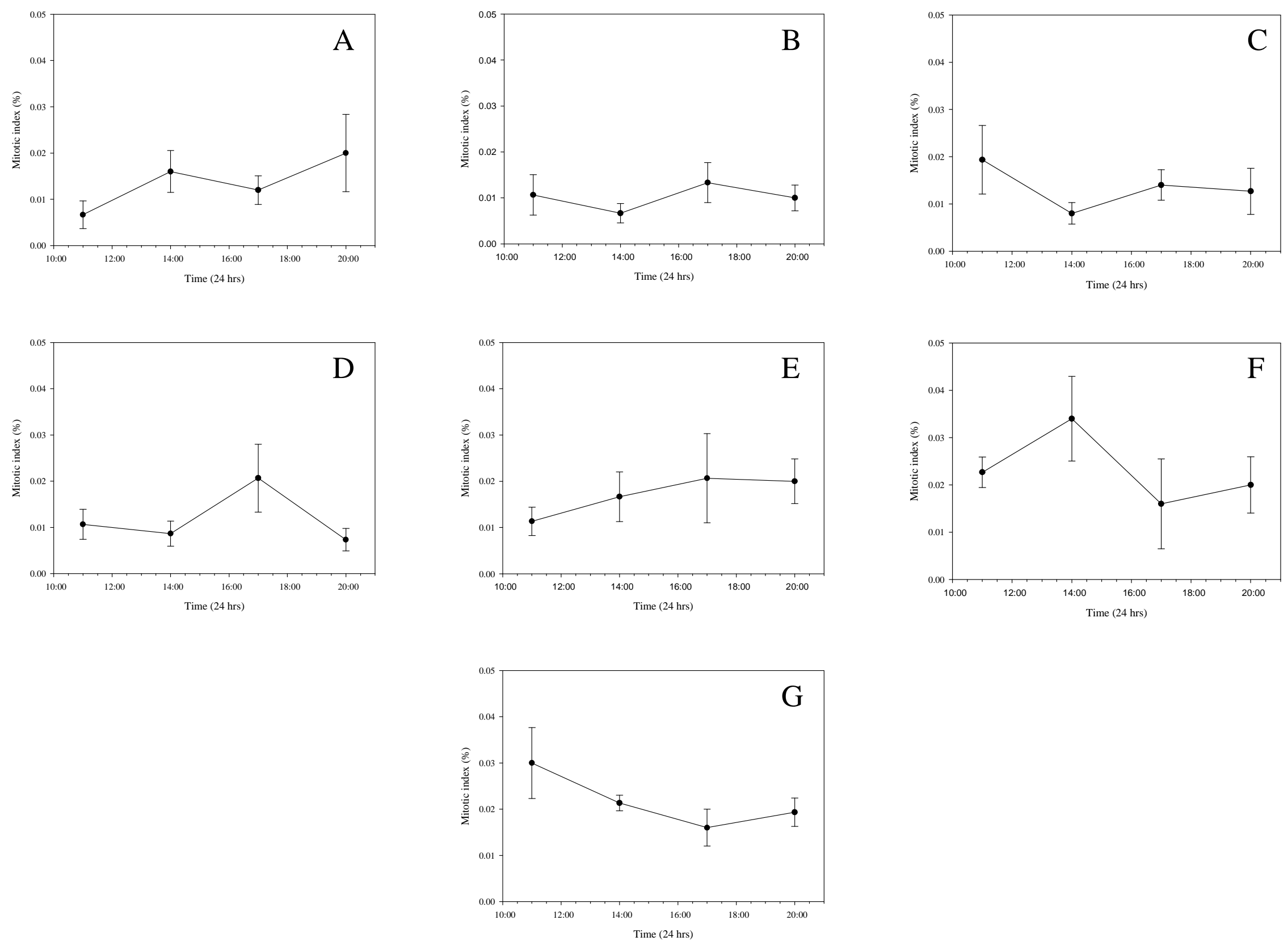

Figure 5.2. Mitotic index for zooxanthellae in Anthopleura aureoradiata under rapid temperature change. $(\boldsymbol{A}) 5^{\circ} \mathrm{C}(\boldsymbol{B}) 10^{\circ} \mathrm{C}$ (C) $15^{\circ} \mathrm{C}(\boldsymbol{D}) 25^{\circ} \mathrm{C}(\boldsymbol{E}) 30^{\circ} \mathrm{C}(\boldsymbol{F}) 32.5^{\circ} \mathrm{C}(\boldsymbol{G}) 32.5^{\circ} \mathrm{C}$; values are means $\pm 1 \mathrm{SE}$. 


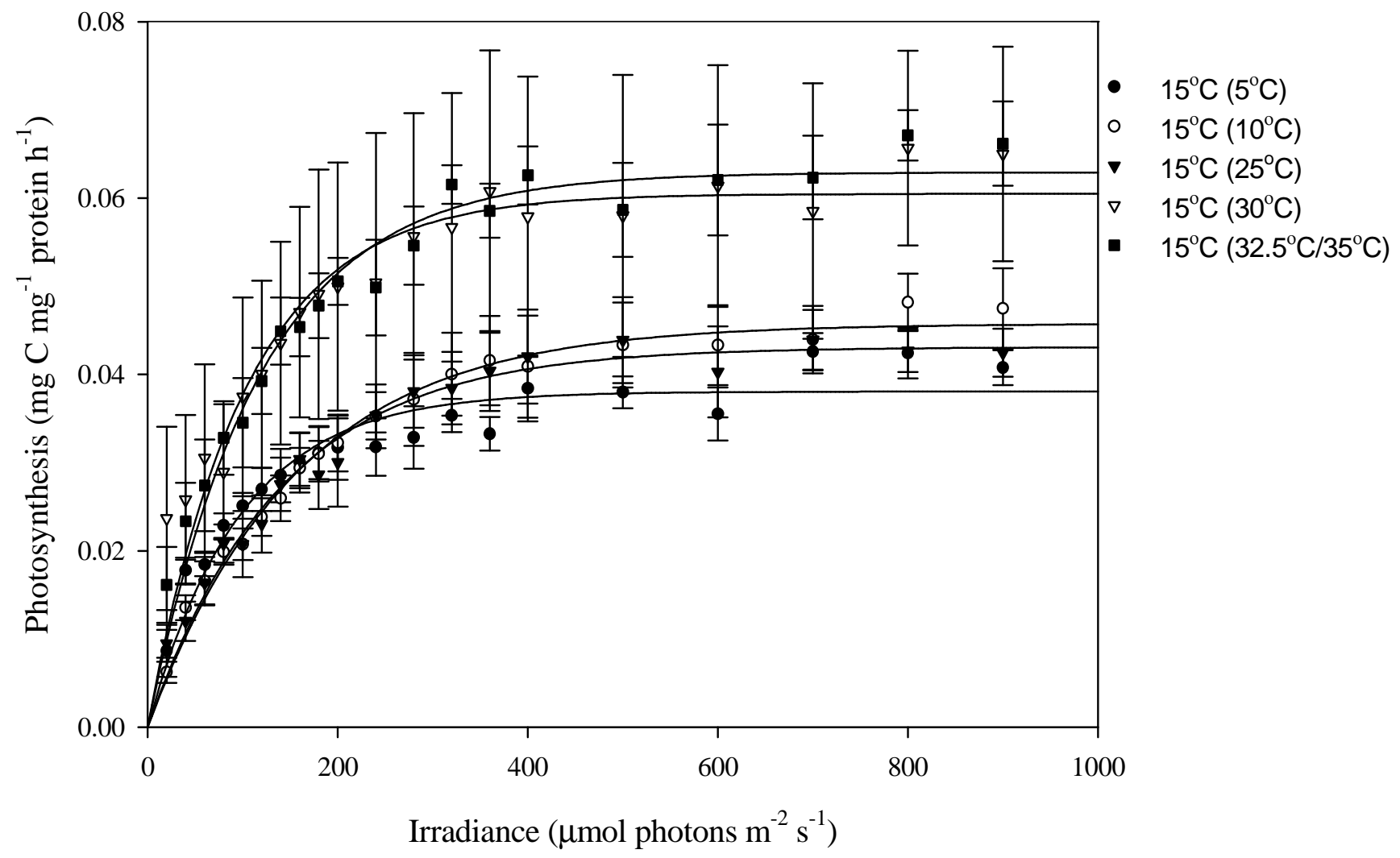

Figure 5.3. Photosynthesis vs. irradiance curves for Anthopleura aureoradiata subjected to control temperature $(n=3)$; values are mean \pm 1 SE. 
Table 5.10. Parameters used in the estimation of CZAR for A. aureoradiata for temperature control treatments. $(\mu=$ cell specific growth rate; $\mathrm{P}_{\mathrm{z}}=$ predicted net photosynthesis by zooxanthellae; $\mu_{\mathrm{c}}=$ carbon specific growth rate; $\mathrm{T}=$ percentage of net fixed carbon translocated to host; $\mathrm{R}_{\mathrm{a}}=$ predicted animal respiration per day).

\begin{tabular}{|c|c|c|c|c|c|}
\hline Parameter & $\begin{array}{l}15^{\circ} \mathrm{C} \\
\left(5^{\circ} \mathrm{C}\right)\end{array}$ & $\begin{array}{l}15^{\circ} \mathrm{C} \\
\left(10^{\circ} \mathrm{C}\right)\end{array}$ & $\begin{array}{l}15^{\circ} \mathrm{C} \\
\left(25^{\circ} \mathrm{C}\right)\end{array}$ & $\begin{array}{l}15^{\circ} \mathrm{C} \\
\left(30^{\circ} \mathrm{C}\right)\end{array}$ & $\begin{array}{c}15^{\circ} \mathrm{C} \\
\left(32.5^{\circ} \mathrm{C} / 35^{\circ} \mathrm{C}\right)\end{array}$ \\
\hline$\mu\left(\mathrm{d}^{-1}\right)$ & 0.033 & 0.033 & 0.033 & 0.033 & 0.033 \\
\hline $\begin{array}{c}\mathrm{P}_{\mathrm{z}} \text { net } \\
\left(\mu \mathrm{g} \mathrm{C} \mathrm{\textrm {gg } ^ { - 1 }} \text { protein } \mathrm{d}^{-1}\right)\end{array}$ & 78.72 & 236.88 & 123.96 & 168.36 & 198 \\
\hline$\mu_{c}\left(d^{-1}\right)$ & 0.067 & 0.214 & 0.096 & 0.127 & 0.122 \\
\hline $\mathrm{T}(\%)$ & 0.51 & 0.85 & 0.66 & 0.74 & 0.73 \\
\hline$\underset{\left(\mu \mathrm{g} \mathrm{C} \mathrm{mg}^{-1} \text { protein } \mathrm{d}^{-1}\right)}{\mathrm{R}_{\mathrm{a}}}$ & 312 & 328.8 & 301.44 & 407.28 & 342.72 \\
\hline CZAR & 12.9 & 61.2 & 27.6 & 30.6 & 42.8 \\
\hline
\end{tabular}




\section{Appendix D}

Post-hoc Tukey HSD tests for gradual and rapid temperature change parameters

Table 5.11 Post-hoc Tukey HSD for the algal density under gradual temperature change.

\begin{tabular}{l|lllllll}
\hline & $\mathbf{5}^{\circ} \mathbf{C}$ & $\mathbf{1 0}^{\circ} \mathbf{C}$ & $\mathbf{1 5}^{\circ} \mathbf{C}$ & $\mathbf{2 5}^{\circ} \mathbf{C}$ & $\mathbf{3 0}^{\circ} \mathbf{C}$ & $\mathbf{3 2 . 5}^{\circ} \mathbf{C}$ & $\mathbf{3 5}^{\circ} \mathbf{C}$ \\
\hline $\mathbf{5}^{\circ} \mathbf{C}$ & & & & & & & \\
$\mathbf{1 0}^{\circ} \mathbf{C}$ & 0.982 & & & & & & \\
$\mathbf{1 5}^{\circ} \mathbf{C}$ & 0.699 & 0.262 & & & & & \\
$\mathbf{2 5}^{\circ} \mathbf{C}$ & 0.894 & 0.44 & 1 & & & & \\
$\mathbf{3 0}^{\circ} \mathbf{C}$ & 0.81 & 0.335 & 1 & 1 & & & \\
$\mathbf{3 2 . 5}^{\circ} \mathbf{C}$ & 0.844 & 1 & 0.098 & 0.183 & 0.125 & & \\
$\mathbf{3 5}^{\circ} \mathbf{C}$ & 0.88 & 1 & 0.129 & 0.233 & 0.165 & 1 & \\
\hline
\end{tabular}

Table 5.12 Post-hoc Tukey HSD for the mitotic index under gradual temperature change.

\begin{tabular}{l|rllllll}
\hline & $\mathbf{5}^{\circ} \mathbf{C}$ & $\mathbf{1 0}^{\circ} \mathbf{C}$ & $\mathbf{1 5}^{\circ} \mathbf{C}$ & $\mathbf{2 5}^{\circ} \mathbf{C}$ & $\mathbf{3 0}^{\circ} \mathbf{C}$ & $\mathbf{3 2 . 5}^{\circ} \mathbf{C}$ & $\mathbf{3 5}^{\circ} \mathbf{C}$ \\
\hline $\mathbf{5}^{\circ} \mathbf{C}$ & & & & & & & \\
$\mathbf{1 0}^{\circ} \mathbf{C}$ & 0.982 & & & & & & \\
$\mathbf{1 5}^{\circ} \mathbf{C}$ & 0.974 & 0.611 & & & & & \\
$\mathbf{2 5}^{\circ} \mathbf{C}$ & 0.535 & 0.953 & 0.104 & & & & \\
$\mathbf{3 0}^{\circ} \mathbf{C}$ & 0.834 & 0.325 & 0.999 & 0.031 & & & \\
$\mathbf{3 2 . 5}^{\circ} \mathbf{C}$ & 0.101 & 0.01 & 0.528 & $<0.001$ & 0.809 & & \\
$\mathbf{3 5}^{\circ} \mathbf{C}$ & 0.128 & 0.013 & 0.595 & $<0.001$ & 0.858 & 1 & \\
\hline
\end{tabular}

Table 5.11 Post-hoc Tukey HSD for $\alpha$ under gradual temperature change.

\begin{tabular}{l|lllllll}
\hline & $\mathbf{5}^{\circ} \mathbf{C}$ & $\mathbf{1 0}^{\circ} \mathbf{C}$ & $\mathbf{1 5}^{\circ} \mathbf{C}$ & $\mathbf{2 5}^{\circ} \mathbf{C}$ & $\mathbf{3 0}^{\circ} \mathbf{C}$ & $\mathbf{3 2 . 5}^{\circ} \mathbf{C}$ & $\mathbf{3 5}^{\circ} \mathbf{C}$ \\
\hline $\mathbf{5}^{\circ} \mathbf{C}$ & & & & & & & \\
$\mathbf{1 0}^{\circ} \mathbf{C}$ & 1 & & & & & & \\
$\mathbf{1 5}^{\circ} \mathbf{C}$ & 0.979 & 0.992 & & & & & \\
$\mathbf{2 5}^{\circ} \mathbf{C}$ & 0.029 & 0.042 & 0.247 & & & & \\
$\mathbf{3 0}^{\circ} \mathbf{C}$ & 0.023 & 0.034 & 0.231 & 1 & & & \\
$\mathbf{3 2 . 5}^{\circ} \mathbf{C}$ & $<0.001$ & $<0.001$ & $<0.001$ & 0.153 & 0.109 & & \\
$\mathbf{3 5}^{\circ} \mathbf{C}$ & 0.257 & 0.33 & 0.808 & 0.936 & 0.939 & 0.015 & \\
\hline
\end{tabular}

Table 5.12 Post-hoc Tukey HSD for respiration under gradual temperature change.

\begin{tabular}{l|lllllll}
\hline & $\mathbf{5}^{\circ} \mathbf{C}$ & $\mathbf{1 0}^{\circ} \mathbf{C}$ & $\mathbf{1 5}^{\circ} \mathbf{C}$ & $\mathbf{2 5}^{\circ} \mathbf{C}$ & $\mathbf{3 0}^{\circ} \mathbf{C}$ & $\mathbf{3 2 . 5}^{\circ} \mathbf{C}$ & $\mathbf{3 5}^{\circ} \mathbf{C}$ \\
\hline $\mathbf{5}^{\circ} \mathbf{C}$ & & & & & & & \\
$\mathbf{1 0}^{\circ} \mathbf{C}$ & 0.975 & & & & & & \\
$\mathbf{1 5}^{\circ} \mathbf{C}$ & 0.824 & 0.998 & & & & & \\
$\mathbf{2 5}^{\circ} \mathbf{C}$ & $<0.001$ & 0.006 & 0.04 & & & & \\
$\mathbf{3 0}^{\circ} \mathbf{C}$ & $<0.001$ & $<0.001$ & 0.002 & 0.929 & & & \\
$\mathbf{3 2 . 5}^{\circ} \mathbf{C}$ & $<0.001$ & $<0.001$ & $<0.001$ & $<0.001$ & $<0.001$ & & \\
$\mathbf{3 5}^{\circ} \mathbf{C}$ & $<0.001$ & $<0.001$ & $<0.001$ & 0.204 & 0.735 & 0.007 & \\
\hline
\end{tabular}


Table 5.13 Post-hoc Tukey HSD for $\mathrm{I}_{\mathrm{c}}$ under gradual temperature change.

\begin{tabular}{l|lllll}
\hline & $\mathbf{5}^{\circ} \mathbf{C}$ & $\mathbf{1 0}^{\circ} \mathbf{C}$ & $\mathbf{1 5}^{\circ} \mathbf{C}$ & $\mathbf{2 5}^{\circ} \mathbf{C}$ & $\mathbf{3 0}^{\circ} \mathbf{C}$ \\
\hline $\mathbf{5}^{\circ} \mathbf{C}$ & & & & & \\
$\mathbf{1 0}^{\circ} \mathbf{C}$ & 0.454 & & & & \\
$\mathbf{1 5}^{\circ} \mathbf{C}$ & 0.645 & 1 & & & \\
$\mathbf{2 5}^{\circ} \mathbf{C}$ & $<0.001$ & 0.033 & 0.03 & & \\
$\mathbf{3 0}^{\circ} \mathbf{C}$ & $<0.001$ & $<0.001$ & $<0.001$ & 0.021 & \\
\hline
\end{tabular}

Table 5.14 Post-hoc Tukey HSD for $\mathrm{I}_{\mathrm{k}}$ under gradual temperature change.

\begin{tabular}{l|lllllll}
\hline & $\mathbf{5}^{\circ} \mathbf{C}$ & $\mathbf{1 0}^{\circ} \mathbf{C}$ & $\mathbf{1 5}^{\circ} \mathbf{C}$ & $\mathbf{2 5}^{\circ} \mathbf{C}$ & $\mathbf{3 0}^{\circ} \mathbf{C}$ & $\mathbf{3 2 . 5}^{\circ} \mathbf{C}$ & $\mathbf{3 5}^{\circ} \mathbf{C}$ \\
\hline $\mathbf{5}^{\circ} \mathbf{C}$ & & & & & & & \\
$\mathbf{1 0}^{\circ} \mathbf{C}$ & 0.144 & & & & & & \\
$\mathbf{1 5}^{\circ} \mathbf{C}$ & 0.002 & 0.425 & & & & & \\
$\mathbf{2 5}^{\circ} \mathbf{C}$ & 0.048 & 0.998 & 0.725 & & & & \\
$\mathbf{3 0}^{\circ} \mathbf{C}$ & 0.027 & 0.995 & 0.745 & 1 & & & \\
$\mathbf{3 2 . 5}^{\circ} \mathbf{C}$ & 0.514 & 0.983 & 0.117 & 0.838 & 0.755 & & \\
$\mathbf{3 5}^{\circ} \mathbf{C}$ & 0.814 & 0.845 & 0.042 & 0.545 & 0.434 & 0.999 & \\
\hline
\end{tabular}

Table 5.15 Post-hoc Tukey HSD for cell specific Pmaxgross under gradual temperature.

\begin{tabular}{l|lllllll}
\hline & $\mathbf{5}^{\circ} \mathbf{C}$ & $\mathbf{1 0}^{\circ} \mathbf{C}$ & $\mathbf{1 5}^{\circ} \mathbf{C}$ & $\mathbf{2 5}^{\circ} \mathbf{C}$ & $\mathbf{3 0}^{\circ} \mathbf{C}$ & $\mathbf{3 2 . 5}^{\circ} \mathbf{C}$ & $\mathbf{3 5}^{\circ} \mathbf{C}$ \\
\hline $\mathbf{5}^{\circ} \mathbf{C}$ & & & & & & & \\
$\mathbf{1 0}^{\circ} \mathbf{C}$ & 0.433 & & & & & & \\
$\mathbf{1 5}^{\circ} \mathbf{C}$ & 0.061 & 0.891 & & & & & \\
$\mathbf{2 5}^{\circ} \mathbf{C}$ & $<0.001$ & 0.023 & 0.37 & & & & \\
$\mathbf{3 0}^{\circ} \mathbf{C}$ & $<0.001$ & 0.004 & 0.127 & 0.997 & & & \\
$\mathbf{3 2 . 5}^{\circ} \mathbf{C}$ & $<0.001$ & $<0.001$ & $<0.001$ & $<0.001$ & $<0.001$ & & \\
$\mathbf{3 5}^{\circ} \mathbf{C}$ & 0.005 & 0.0365 & 0.805 & 0.805 & 0.429 & $<0.001$ & \\
\hline
\end{tabular}

Table 5.16 Post-hoc Tukey HSD for Pmaxgross under gradual temperature.

\begin{tabular}{l|lllllll}
\hline & $\mathbf{5}^{\circ} \mathbf{C}$ & $\mathbf{1 0}^{\circ} \mathbf{C}$ & $\mathbf{1 5}^{\circ} \mathbf{C}$ & $\mathbf{2 5}^{\circ} \mathbf{C}$ & $\mathbf{3 0}^{\circ} \mathbf{C}$ & $\mathbf{3 2 . 5}^{\circ} \mathbf{C}$ & $\mathbf{3 5}^{\circ} \mathbf{C}$ \\
\hline $\mathbf{5}^{\circ} \mathbf{C}$ & & & & & & & \\
$\mathbf{1 0} \mathbf{C}$ & 0.549 & & & & & & \\
$\mathbf{1 5}^{\circ} \mathbf{C}$ & 0.005 & 0.226 & & & & & \\
$\mathbf{2 5}^{\circ} \mathbf{C}$ & $<0.001$ & $<0.001$ & 0.158 & & & & \\
$\mathbf{3 0}^{\circ} \mathbf{C}$ & $<0.001$ & $<0.001$ & 0.064 & 1 & & & \\
$\mathbf{3 2 . 5}^{\circ} \mathbf{C}$ & $<0.001$ & $<0.001$ & $<0.001$ & 0.107 & 0.168 & & \\
$\mathbf{3 5}^{\circ} \mathbf{C}$ & 0.019 & 0.583 & 0.987 & 0.019 & 0.005 & $<0.001$ & \\
\hline
\end{tabular}


Table 5.17 Post-hoc Tukey HSD for algal density under rapid temperature change.

\begin{tabular}{l|lllllll}
\hline & $\mathbf{5}^{\circ} \mathbf{C}$ & $\mathbf{1 0}^{\circ} \mathbf{C}$ & $\mathbf{1 5}^{\circ} \mathbf{C}$ & $\mathbf{2 5}^{\circ} \mathbf{C}$ & $\mathbf{3 0}^{\circ} \mathbf{C}$ & $\mathbf{3 2 . 5}^{\circ} \mathbf{C}$ & $\mathbf{3 5}^{\circ} \mathbf{C}$ \\
\hline $\mathbf{5}^{\circ} \mathbf{C}$ & & & & & & & \\
$\mathbf{1 0}^{\circ} \mathbf{C}$ & 0.986 & & & & & & \\
$\mathbf{1 5}^{\circ} \mathbf{C}$ & 0.846 & 0.998 & & & & & \\
$\mathbf{2 5}^{\circ} \mathbf{C}$ & 1 & 0.905 & 0.633 & & & & \\
$\mathbf{3 0}^{\circ} \mathbf{C}$ & 0.998 & 1 & 0.985 & 0.969 & & & \\
$\mathbf{3 2 . 5}^{\circ} \mathbf{C}$ & 1 & 0.941 & 0.707 & 1 & 0.985 & & \\
$\mathbf{3 5}^{\circ} \mathbf{C}$ & 0.443 & 0.883 & 0.992 & 0.249 & 0.762 & 0.303 & \\
\hline
\end{tabular}

Table 5.18 Post-hoc Tukey HSD for the mitotic index under rapid temperature change.

\begin{tabular}{l|lllllll}
\hline & $\mathbf{5}^{\circ} \mathbf{C}$ & $\mathbf{1 0}^{\circ} \mathbf{C}$ & $\mathbf{1 5}^{\circ} \mathbf{C}$ & $\mathbf{2 5}^{\circ} \mathbf{C}$ & $\mathbf{3 0}^{\circ} \mathbf{C}$ & $\mathbf{3 2 . 5}^{\circ} \mathbf{C}$ & $\mathbf{3 5}^{\circ} \mathbf{C}$ \\
\hline $\mathbf{5}^{\circ} \mathbf{C}$ & & & & & & & \\
$\mathbf{1 0}^{\circ} \mathbf{C}$ & 0.98 & & & & & & \\
$\mathbf{1 5}^{\circ} \mathbf{C}$ & 1 & 0.907 & & & & & \\
$\mathbf{2 5}^{\circ} \mathbf{C}$ & 1 & 0.994 & 0.999 & & & & \\
$\mathbf{3 0}^{\circ} \mathbf{C}$ & 0.888 & 0.387 & 0.974 & 0.81 & & & \\
$\mathbf{3 2 . 5}^{\circ} \mathbf{C}$ & 0.171 & 0.019 & 0.32 & 0.117 & 0.861 & & \\
$\mathbf{3 5}^{\circ} \mathbf{C}$ & 0.119 & 0.011 & 0.237 & 0.078 & 0.778 & 1 & \\
\hline
\end{tabular}

Table 5.19 Post-hoc Tukey HSD for $\alpha$ under rapid temperature change.

\begin{tabular}{|c|c|c|c|c|c|c|c|}
\hline & $5^{\circ} \mathrm{C}$ & $10^{\circ} \mathrm{C}$ & $15^{\circ} \mathrm{C}$ & $25^{\circ} \mathrm{C}$ & $30^{\circ} \mathrm{C}$ & $32.5^{\circ} \mathrm{C}$ & $35^{\circ} \mathrm{C}$ \\
\hline $5^{\circ} \mathrm{C}$ & & & & & & & \\
\hline${ }^{10^{\circ} \mathrm{C}}$ & 1 & & & & & & \\
\hline $15^{\circ} \mathrm{C}$ & 1 & 1 & & & & & \\
\hline $25^{\circ} \mathrm{C}$ & 1 & 0.998 & 1 & & & & \\
\hline $30^{\circ} \mathrm{C}$ & 0.708 & 0.656 & 0.75 & 0.927 & & & \\
\hline $32.5^{\circ} \mathrm{C}$ & 0.046 & 0.038 & 0.054 & 0.125 & 0.651 & & \\
\hline $35^{\circ} \mathrm{C}$ & $<0.001$ & $<0.001$ & $<0.001$ & $<0.001$ & $<0.001$ & $<0.001$ & \\
\hline
\end{tabular}

Table 5.20 Post-hoc Tukey HSD for respiration under rapid temperature change.

\begin{tabular}{l|ccccccc}
\hline & $\mathbf{5}^{\circ} \mathbf{C}$ & $\mathbf{1 0}^{\circ} \mathbf{C}$ & $\mathbf{1 5}^{\circ} \mathbf{C}$ & $\mathbf{2 5}^{\circ} \mathbf{C}$ & $\mathbf{3 0}^{\circ} \mathbf{C}$ & $\mathbf{3 2 . 5}^{\circ} \mathbf{C}$ & $\mathbf{3 5}^{\circ} \mathbf{C}$ \\
\hline $\mathbf{5}^{\circ} \mathbf{C}$ & & & & & & & \\
$\mathbf{1 0}^{\circ} \mathbf{C}$ & 0.804 & & & & & \\
$\mathbf{1 5}^{\circ} \mathbf{C}$ & 0.196 & 0.918 & & & & & \\
$\mathbf{2 5}^{\circ} \mathbf{C}$ & 0.013 & 0.249 & 0.868 & & & & \\
$\mathbf{3 0}^{\circ} \mathbf{C}$ & $<0.001$ & $<0.001$ & 0.002 & 0.042 & & & \\
$\mathbf{3 2 . 5}^{\circ} \mathbf{C}$ & $<0.001$ & $<0.001$ & $<0.001$ & 0.003 & 0.93 & & \\
$\mathbf{3 5}^{\circ} \mathbf{C}$ & $<0.001$ & $<0.001$ & $<0.001$ & $<0.001$ & $<0.001$ & 0.007 & \\
\hline
\end{tabular}


Table 5.21 Post-hoc Tukey HSD for $\mathrm{I}_{\mathrm{k}}$ under rapid temperature change.

\begin{tabular}{l|lllll}
\hline & $\mathbf{5}^{\circ} \mathbf{C}$ & $\mathbf{1 0}^{\circ} \mathbf{C}$ & $\mathbf{1 5}^{\circ} \mathbf{C}$ & $\mathbf{2 5}^{\circ} \mathbf{C}$ & $\mathbf{3 0}^{\circ} \mathbf{C}$ \\
\hline $\mathbf{5}^{\circ} \mathbf{C}$ & & & & & \\
$\mathbf{1 0}^{\circ} \mathbf{C}$ & 0.777 & & & & \\
$\mathbf{1 5}^{\circ} \mathbf{C}$ & 0.56 & 0.99 & & & \\
$\mathbf{2 5}^{\circ} \mathbf{C}$ & 0.01 & 0.068 & 0.2 & & \\
$\mathbf{3 0}^{\circ} \mathbf{C}$ & 0.017 & 0.076 & 0.167 & 0.964 & \\
\hline
\end{tabular}

Table 5.22 Post-hoc Tukey HSD for $\mathrm{I}_{\mathrm{c}}$ under rapid temperature change.

\begin{tabular}{l|lllllll}
\hline & \multicolumn{1}{|c}{$\mathbf{5}^{\circ} \mathbf{C}$} & $\mathbf{1 0}^{\circ} \mathbf{C}$ & $\mathbf{1 5}^{\circ} \mathbf{C}$ & $\mathbf{2 5}^{\circ} \mathbf{C}$ & $\mathbf{3 0}^{\circ} \mathbf{C}$ & $\mathbf{3 2 . 5}^{\circ} \mathbf{C}$ & $\mathbf{3 5}^{\circ} \mathbf{C}$ \\
\hline $\mathbf{5}^{\circ} \mathbf{C}$ & & & & & & & \\
$\mathbf{1 0}^{\circ} \mathbf{C}$ & 0.007 & & & & & & \\
$\mathbf{1 5}^{\circ} \mathbf{C}$ & $<0.001$ & 0.975 & & & & & \\
$\mathbf{2 5}^{\circ} \mathbf{C}$ & $<0.001$ & 0.993 & 1 & & & & \\
$\mathbf{3 0}^{\circ} \mathbf{C}$ & 0.046 & 0.987 & 0.67 & 0.779 & & & \\
$\mathbf{3 2 . 5}^{\circ} \mathbf{C}$ & 1 & 0.02 & 0.002 & 0.004 & 0.110 & & \\
$\mathbf{3 5}^{\circ} \mathbf{C}$ & 0.823 & $<0.001$ & $<0.002$ & $<0.001$ & 0.002 & 0.587 & \\
\hline
\end{tabular}

Table 5.23 Post-hoc Tukey HSD for cell specific $\mathrm{P}_{\max }$ gross under rapid temperature.

\begin{tabular}{l|lllllll}
\hline & $\mathbf{5}^{\circ} \mathbf{C}$ & $\mathbf{1 0}^{\circ} \mathbf{C}$ & $\mathbf{1 5}^{\circ} \mathbf{C}$ & $\mathbf{2 5}^{\circ} \mathbf{C}$ & $\mathbf{3 0}^{\circ} \mathbf{C}$ & $\mathbf{3 2 . 5}^{\circ} \mathbf{C}$ & $\mathbf{3 5}^{\circ} \mathbf{C}$ \\
\hline $\mathbf{5}^{\circ} \mathbf{C}$ & & & & & & & \\
$\mathbf{1 0}^{\circ} \mathbf{C}$ & 0.096 & & & & & & \\
$\mathbf{1 5}^{\circ} \mathbf{C}$ & 0.011 & 0.964 & & & & & \\
$\mathbf{2 5}^{\circ} \mathbf{C}$ & $<0.001$ & 0.507 & 0.961 & & & & \\
$\mathbf{3 0}^{\circ} \mathbf{C}$ & $<0.001$ & $<0.001$ & 0.013 & 0.115 & & & \\
$\mathbf{3 2 . 5}^{\circ} \mathbf{C}$ & $<0.001$ & $<0.001$ & 0.01 & 0.093 & 1 & & \\
$\mathbf{3 5}^{\circ} \mathbf{C}$ & $<0.001$ & $<0.001$ & $<0.001$ & $<0.001$ & 0.86 & 0.108 & \\
\hline
\end{tabular}

Table 5.24 Post-hoc Tukey HSD for $\mathrm{P}_{\max }$ gross under rapid temperature change.

\begin{tabular}{l|lllllll}
\hline & $\mathbf{5}^{\circ} \mathbf{C}$ & $\mathbf{1 0}^{\circ} \mathbf{C}$ & $\mathbf{1 5}^{\circ} \mathbf{C}$ & $\mathbf{2 5}^{\circ} \mathbf{C}$ & $\mathbf{3 0}^{\circ} \mathbf{C}$ & $\mathbf{3 2 . 5}^{\circ} \mathbf{C}$ & $\mathbf{3 5}^{\circ} \mathbf{C}$ \\
\hline $\mathbf{5}^{\circ} \mathbf{C}$ & & & & & & & \\
$\mathbf{1 0}^{\circ} \mathbf{C}$ & 0.096 & & & & & & \\
$\mathbf{1 5}^{\circ} \mathbf{C}$ & 0.011 & 0.964 & & & & & \\
$\mathbf{2 5}^{\circ} \mathbf{C}$ & $<0.001$ & 0.507 & 0.961 & & & & \\
$\mathbf{3 0}^{\circ} \mathbf{C}$ & $<0.001$ & $<0.001$ & 0.013 & 0.115 & & & \\
$\mathbf{3 2 . 5}^{\circ} \mathbf{C}$ & $<0.001$ & $<0.001$ & 0.01 & 0.093 & 1 & & \\
$\mathbf{3 5}^{\circ} \mathbf{C}$ & $<0.001$ & $<0.001$ & $<0.001$ & $<0.001$ & 0.86 & 0.108 & \\
\hline
\end{tabular}


Table 5.25 Post-hoc Tukey HSD for algal density under control temperature treatments.

\begin{tabular}{|c|c|c|c|c|c|}
\hline & $\begin{array}{l}15^{\circ} \mathrm{C} \\
\left(5^{\circ} \mathrm{C}\right)\end{array}$ & $\begin{array}{c}15^{\circ} \mathrm{C} \\
\left(10^{\circ} \mathrm{C}\right)\end{array}$ & $\begin{array}{l}15^{\circ} \mathrm{C} \\
\left(25^{\circ} \mathrm{C}\right)\end{array}$ & $\begin{array}{c}15^{\circ} \mathrm{C} \\
\left(30^{\circ} \mathrm{C}\right)\end{array}$ & $\begin{array}{c}15^{\circ} \mathrm{C} \\
\left(32.5^{\circ} \mathrm{C} / 35^{\circ} \mathrm{C}\right)\end{array}$ \\
\hline $15^{\circ} \mathrm{C}\left(5^{\circ} \mathrm{C}\right)$ & & & & & \\
\hline $15^{\circ} \mathrm{C}\left(10^{\circ} \mathrm{C}\right)$ & 0.993 & & & & \\
\hline $15^{\circ} \mathrm{C}\left(25^{\circ} \mathrm{C}\right)$ & 0.955 & 0.801 & & & \\
\hline $1^{\circ} \mathrm{C}\left(30^{\circ} \mathrm{C}\right)$ & 0.881 & 0.674 & 1 & & \\
\hline${ }^{15^{\circ}} \mathrm{C}\left(32.5^{\circ} \mathrm{C} / 35^{\circ} \mathrm{C}\right)$ & 0.133 & 0.071 & 0.348 & 0.462 & \\
\hline
\end{tabular}

Table 5.26 Post-hoc Tukey HSD for $\alpha$ under control temperature treatments.

\begin{tabular}{|c|c|c|c|c|c|}
\hline & $\begin{array}{l}15^{\circ} \mathrm{C} \\
\left(5^{\circ} \mathrm{C}\right)\end{array}$ & $\begin{array}{c}15^{\circ} \mathrm{C} \\
\left(10^{\circ} \mathrm{C}\right)\end{array}$ & $\begin{array}{l}15^{\circ} \mathrm{C} \\
\left(25^{\circ} \mathrm{C}\right)\end{array}$ & $\begin{array}{c}15^{\circ} \mathrm{C} \\
\left(30^{\circ} \mathrm{C}\right)\end{array}$ & $\begin{array}{c}15^{\circ} \mathrm{C} \\
\left(32.5^{\circ} \mathrm{C} / 35^{\circ} \mathrm{C}\right)\end{array}$ \\
\hline $15^{\circ} \mathrm{C}\left(5^{\circ} \mathrm{C}\right)$ & & & & & \\
\hline $15^{\circ} \mathrm{C}\left(10^{\circ} \mathrm{C}\right)$ & 0.937 & & & & \\
\hline $15^{\circ} \mathrm{C}\left(25^{\circ} \mathrm{C}\right)$ & 0.982 & 0.999 & & & \\
\hline $15^{\circ} \mathrm{C}\left(30^{\circ} \mathrm{C}\right)$ & 0.784 & 0.377 & 0.492 & & \\
\hline $15^{\circ} \mathrm{C}\left(32.5^{\circ} \mathrm{C} / 35^{\circ} \mathrm{C}\right)$ & 0.846 & 0.44 & 0.562 & 1 & \\
\hline
\end{tabular}

Table 5.27 Post-hoc Tukey HSD for respiration under control temperature treatments.

\begin{tabular}{|c|c|c|c|c|c|}
\hline & $\begin{array}{l}15^{\circ} \mathrm{C} \\
\left(5^{\circ} \mathrm{C}\right)\end{array}$ & $\begin{array}{c}15^{\circ} \mathrm{C} \\
\left(10^{\circ} \mathrm{C}\right)\end{array}$ & $\begin{array}{c}15^{\circ} \mathrm{C} \\
\left(25^{\circ} \mathrm{C}\right)\end{array}$ & $\begin{array}{c}15^{\circ} \mathrm{C} \\
\left(30^{\circ} \mathrm{C}\right)\end{array}$ & $\begin{array}{c}15^{\circ} \mathrm{C} \\
\left(32.5^{\circ} \mathrm{C} / 35^{\circ} \mathrm{C}\right)\end{array}$ \\
\hline $15^{\circ} \mathrm{C}\left(5^{\circ} \mathrm{C}\right)$ & & & & & \\
\hline $15^{\circ} \mathrm{C}\left(10^{\circ} \mathrm{C}\right)$ & 1 & & & & \\
\hline $15^{\circ} \mathrm{C}\left(25^{\circ} \mathrm{C}\right)$ & 1 & 1 & & & \\
\hline $1^{\circ} \mathrm{C}\left(30^{\circ} \mathrm{C}\right)$ & 0.575 & 0.592 & 0.61 & & \\
\hline $15^{\circ} \mathrm{C}\left(32.5^{\circ} \mathrm{C} / 35^{\circ} \mathrm{C}\right)$ & 0.705 & 0.721 & 0.738 & 1 & \\
\hline
\end{tabular}

Table 5.28 Post-hoc Tukey HSD for $\mathrm{I}_{\mathrm{c}}$ under control temperature treatments.

\begin{tabular}{|c|c|c|c|c|c|}
\hline & $\begin{array}{l}15^{\circ} \mathrm{C} \\
\left(5^{\circ} \mathrm{C}\right)\end{array}$ & $\begin{array}{c}15^{\circ} \mathrm{C} \\
\left(10^{\circ} \mathrm{C}\right)\end{array}$ & $\begin{array}{c}15^{\circ} \mathrm{C} \\
\left(25^{\circ} \mathrm{C}\right)\end{array}$ & $\begin{array}{c}15^{\circ} \mathrm{C} \\
\left(30^{\circ} \mathrm{C}\right)\end{array}$ & $\begin{array}{c}15^{\circ} \mathrm{C} \\
\left(32.5^{\circ} \mathrm{C} / 35^{\circ} \mathrm{C}\right)\end{array}$ \\
\hline $15^{\circ} \mathrm{C}\left(5^{\circ} \mathrm{C}\right)$ & & & & & \\
\hline $15^{\circ} \mathrm{C}\left(10^{\circ} \mathrm{C}\right)$ & 0.738 & & & & \\
\hline $15^{\circ} \mathrm{C}\left(25^{\circ} \mathrm{C}\right)$ & 0.526 & 0.995 & & & \\
\hline $1^{\circ} \mathrm{C}\left(30^{\circ} \mathrm{C}\right)$ & 0.998 & 0.575 & 0.378 & & \\
\hline $1^{\circ} \mathrm{C}\left(32.5^{\circ} \mathrm{C} / 35^{\circ} \mathrm{C}\right)$ & 0.989 & 0.478 & 0.302 & 1 & \\
\hline
\end{tabular}


Table 5.30 Post-hoc Tukey HSD for $\mathrm{I}_{\mathrm{k}}$ under control temperature treatments.

\begin{tabular}{|c|c|c|c|c|c|}
\hline & $\begin{array}{l}15^{\circ} \mathrm{C} \\
\left(5^{\circ} \mathrm{C}\right)\end{array}$ & $\begin{array}{c}15^{\circ} \mathrm{C} \\
\left(10^{\circ} \mathrm{C}\right)\end{array}$ & $\begin{array}{r}15^{\circ} \mathrm{C} \\
\left(25^{\circ} \mathrm{C}\right)\end{array}$ & $\begin{array}{c}15^{\circ} \mathrm{C} \\
\left(30^{\circ} \mathrm{C}\right)\end{array}$ & $\begin{array}{c}15^{\circ} \mathrm{C} \\
\left(32.5^{\circ} \mathrm{C} / 35^{\circ} \mathrm{C}\right)\end{array}$ \\
\hline $15^{\circ} \mathrm{C}\left(5^{\circ} \mathrm{C}\right)$ & & & & & \\
\hline $15^{\circ} \mathrm{C}\left(10^{\circ} \mathrm{C}\right)$ & 0.707 & & & & \\
\hline $15^{\circ} \mathrm{C}\left(25^{\circ} \mathrm{C}\right)$ & 0.979 & 0.945 & & & \\
\hline $1^{\circ} \mathrm{C}\left(30^{\circ} \mathrm{C}\right)$ & 0.203 & 0.813 & 0.421 & & \\
\hline $1^{\circ} \mathrm{C}\left(32.5^{\circ} \mathrm{C} / 35^{\circ} \mathrm{C}\right)$ & 0.145 & 0.692 & 0.316 & 0.999 & \\
\hline
\end{tabular}

Table 5.31 Post-hoc Tukey HSD for cell specific $\mathrm{P}_{\max }$ gross under control temperature treatments.

\begin{tabular}{l|ccccc}
\hline & $\begin{array}{c}\mathbf{1 5}^{\circ} \mathbf{C} \\
\left(5^{\circ} \mathbf{C}\right)\end{array}$ & $\begin{array}{c}\mathbf{1 5}^{\circ} \mathbf{C} \\
\left(\mathbf{1 0}^{\circ} \mathbf{C}\right)\end{array}$ & $\begin{array}{c}\mathbf{1 5}^{\circ} \mathbf{C} \\
\left(\mathbf{2 5}^{\circ} \mathbf{C}\right)\end{array}$ & $\begin{array}{r}\mathbf{1 5}^{\circ} \mathbf{C} \\
\left(\mathbf{3 0}^{\circ} \mathbf{C}\right)\end{array}$ & $\begin{array}{c}\mathbf{1 5}^{\circ} \mathbf{C} \\
\left(\mathbf{3 2 . 5}^{\circ} \mathbf{C} / 35^{\circ} \mathbf{C}\right)\end{array}$ \\
\hline $\mathbf{1 5}^{\circ} \mathbf{C}\left(\mathbf{5}^{\circ} \mathbf{C}\right)$ & & & & & \\
$\mathbf{1 5}^{\circ} \mathbf{C}\left(\mathbf{1 0}^{\circ} \mathbf{C}\right)$ & 0.707 & & & & \\
$\mathbf{1 5}^{\circ} \mathbf{C}\left(\mathbf{2 5}^{\circ} \mathbf{C}\right)$ & 0.979 & 0.945 & & & \\
$\mathbf{1 5}^{\circ} \mathbf{C}\left(\mathbf{3 0}^{\circ} \mathbf{C}\right)$ & 0.203 & 0.813 & 0.421 & & \\
$\mathbf{1 5}^{\circ} \mathbf{C}\left(\mathbf{3 2 . 5}^{\circ} \mathbf{C} / \mathbf{3 5}^{\circ} \mathbf{C}\right)$ & 0.145 & 0.692 & 0.316 & 0.999 & \\
\hline
\end{tabular}

Table 5.32 Post-hoc Tukey HSD for $\mathrm{P}_{\max }$ gross under control temperature treatments.

\begin{tabular}{l|ccccc}
\hline & $\begin{array}{r}\mathbf{1 5}^{\circ} \mathbf{C} \\
\left(5^{\circ} \mathbf{C}\right)\end{array}$ & $\begin{array}{c}\mathbf{1 5}^{\circ} \mathbf{C} \\
\left(\mathbf{1 0}^{\circ} \mathbf{C}\right)\end{array}$ & $\begin{array}{c}\mathbf{1 5}^{\circ} \mathbf{C} \\
\left(\mathbf{2 5}^{\circ} \mathbf{C}\right)\end{array}$ & $\begin{array}{c}\mathbf{1 5}^{\circ} \mathbf{C} \\
\left(\mathbf{3 0}^{\circ} \mathbf{C}\right)\end{array}$ & $\begin{array}{c}\mathbf{1 5}^{\circ} \mathbf{C} \\
\left(\mathbf{3 2 . 5}^{\circ} \mathbf{C} / 35^{\circ} \mathbf{C}\right)\end{array}$ \\
\hline $\mathbf{1 5}^{\circ} \mathbf{C}\left(\mathbf{5}^{\circ} \mathbf{C}\right)$ & & & & & \\
$\mathbf{1 5}^{\circ} \mathbf{C}\left(\mathbf{1 0}^{\circ} \mathbf{C}\right)$ & 0.707 & & & & \\
$\mathbf{1 5}^{\circ} \mathbf{C}\left(\mathbf{2 5}^{\circ} \mathbf{C}\right)$ & 0.979 & 0.945 & & & \\
$\mathbf{1 5}^{\circ} \mathbf{C}\left(\mathbf{3 0}^{\circ} \mathbf{C}\right)$ & 0.203 & 0.813 & 0.421 & & \\
$\mathbf{1 5}^{\circ} \mathbf{C}\left(\mathbf{3 2 . 5}^{\circ} \mathbf{C} / \mathbf{3 5}^{\circ} \mathbf{C}\right)$ & 0.145 & 0.692 & 0.316 & 0.999 & \\
\hline
\end{tabular}




\section{Chapter 6}

\section{References}

Anthony K. R. N. and Fabricius K. E. (2000). Shifting roles of heterotrophy and autotrophy in coral energetics under varying turbidity. Journal of Experimental Marine Biology and Ecology 252: 221 - 253

Anthony K. R. N. and Hoegh-Guldberg O. (2003). Kinetics of photoacclimation in corals. Oecologia 134: $23-31$

Anthony K. R. N., Ridd P. V., Orpin A. R., Larcombe P., and Lough J. (2004). Temporal variation of light availability in coastal benthic habitats: Effects of clouds, turbidity, and tides. Limnology and Oceanography 49: 2201 - 2211

Asada K. (1996). The water-water cycle as alternative photon and electron sinks. Philosophical Transactions of the Royal Society B 355: 1419 - 1431

Asada K. (1999). The water-water cycle in chloroplasts: scavenging of active oxygens and dissipation of excess photons. Annual Review of Plant Physiology and Plant Molecular Biology 50: 601 - 639 
Augustine L. and Muller-Parker G. (1998). Selective predation by the mosshead sculpin Clinocottus globiceps on the sea anemone Anthopleura elegantissima and its two algal symbionts. Limnology and Oceanography 43: 711 - 715

Babcock R. C. and Heyward A. J. (1986). Larval development of certain gametespawning scleractinian corals. Coral Reefs 5: 111 - 116

Baker A. C. (2003). Flexibility and specificity in coral-algal symbiosis: diversity, ecology, and biogeography of Symbiodinium. Annual Review of Ecology and Systematics 34: 661-689

Banaszak A. T., and Trench R. K. (1995). Effects of ultraviolet (UV) radiation on marine microalgal-invertebrate symbioses. I. Response of the algal symbionts in culture and in hospite. Journal of Experimental Marine Biology and Ecology 194: $213-232$

Battey J. F. and Patton J. S. 1987. Glycerol translocation in Condylactis gigantea. Marine Biology 95: $37-46$

Berkelmans R. and Willis B. L. (1999). Seasonal and local spatial patterns in the upper thermal limits of corals on the inshore central Great Barrier Reef. Coral Reefs 18: 219 - 228 
Berkelmans R. and van Oppen M. J. H. (2006). The role of zooxanthellae in the thermal tolerance of corals: a 'nugget of hope' for coral reefs in an era of climate change.Proceedings of the Royal Society B 273: 2305 - 2312

Berner T., Dubinsky Z., Wyman K., and Falkowski P. G. (1989). Photoadaptation and the "package" effect in Dunaliella tertiolecta (Chlorophyceae). Journal of Phycology 25: $70-78$

Bhagooli R. and Hidaka M. (2004). Photoinhibition, bleaching susceptibility and mortality in two scleractinian corals, Platygyra ryukyuensis and Stylophora pistillata, in response to thermal and light stress. Comparative Biochemsitry and Physiology Part A 137: 547 - 555

Bil K., Kolmakov P. V. and Muscatine L. (1992). Photosynthetic products of zooxanthellae of the reef building coral Styzophora pistillata and Seriatophora coliendrum from different depths of the Seychelles Islands. Atoll Research Bulletin 377: 1 - 9

Blank R. J. and Huss V. A. R. (1989). DNA divergency and speciation in Symbiodinium (Dinophyceae). Plant Systematics and Evolution 163: 153 - 163

Brown B. E. and Suharsono. (1990). Damage and recovery of coral reefs affected by El Nino related seawater warming in the Thousand Islands, Indonesia. Coral Reefs 8: $163-170$ 
Brown B. E. (1997). Coral bleaching: causes and consequences. Coral Reefs 16: 129 $-138$

Brown B. E., Dunne R. P., Ambarsari I., Le Tissier M. D. A., and Satapoomin U. (1999). Seasonal fluctuations in environmental factors and variations in symbiotic algae and chlorophyll pigments in four indo-pacific coral species. Marine Ecology Progress Series 191: 53 - 69

Buck B. H., Rosenthal H., and Saint-Paul U. (2002). Effect of increase irradiance and thermal stress on the symbiosis of Symbiodinium microadriaticum and Tridacna gigas. Aquatic Living Resources 15: 107 - 117

Buddemeier R. W. and Fautin D. G. (1993). Coral bleaching as an adaptive mechanism. Bioscience 43: 320 - 326

Carlos A. A. (1999). Phlogenetic position of Symbiodinium (Dinophyceae) isolates from Tridacnids (Bivalvia), Cardiids (Bivalvia), a sponge (Porifera), a spft coral (Anthozoa), and a free-living strain. Journal of Phycology 35: 1054 - 1062

Clark K. B. and Jensen K. R. (1982). Effects of temperature on carbon fixation and carbon budget partitioning in the zooxanthellal symbiosis of Aiptasia pallida (Verrill). Journal of Experimental Marine Biology and Ecology 64: 215 - 230 
Clayton W. S. and Lasker H. R. (1984). Host feeding regime and zooxanthellala photosynthesis in the anemone, Aiptasia pallida (Verrill). Biological Bulletin 167: $590-600$

Coffroth M. A., Santos S. R. and Goulet T. L. (2001). Early ontogentetic expression of specificity in a cnidarian-algal symbiosis. Marine Ecology Progress Series 222: $85-96$

Coffroth M. A. and Santos S. R. (2005). Genetic diversity of symbiotic dinoflagellates in the genus Symbiodinium. Protist 156: 19 - 34

Coles S. L. and Brown B. E. (2003). Coral Bleaching - capacity for acclimatisation and adaptation. Advanced Marine Biology 46: 183 - 223

Coles S. L. and Jokiel P. L. (1977). Effects of temperature on photosynthesis and respiration in hermatypic corals. Marine Biology 43: 209 - 216

Coles S. L. and Jokiel P. L. (1978). Synergistic effects of temperature, salinity and light on the hermatypic coral Montipora verrucosa. Marine Biology 49: 187 195

Cook C. B., D’Elia C. F. and Muller-Parker G. (1988). Host feeding and nutrient sufficiency for zooxanthellae in the sea anemone Aiptasia pallida. Marine Biology 98: 253 - 262 
Cook C. B. and Orlandini J. 1992. Initial studies of host factors inducing photosynthate release in corals (Montastrea annularis) and sea anemones (Aiptasia pulchella). American Zoology 32: 111 - 121

Crossland C. J., Barnes D. L. and Borowitzka M. A. 1980. Diurnal lipid and mucus production in the staghorn coral Acropora acuminate. Marine Biology 60: 81 90

Crossland C. J. (1984). Seasonal variations in the rates of calcification and productivity in the coral Acropora formosa on a high latitude reef. Marine Ecology Progress Series 15: 135 - 140

Davies P. S. (1991). Effect of daylight variations on the energy budgets of shallowwater corals. Marine Biology 108: 137 - 144

Davison I. R. (1991). Environmental effects on algal photosynthesis: Temperature. Journal of Phycology 27: 2 - 8

Davy S. K., Lucas I. A. N. and Turner J. R. (1996). Carbon budgets in temperate anthozoan-dinoflagellate symbiosis. Marine Biology 126: 773 - 783

Davy S. K., Turner J. R. and Lucas I. A. N. (1997). The nature of temperate anthozoan-dinoflagellate symbioses. Proceedings of the $8^{\text {th }}$ Coral Reef Symposium 2: 1307 - 1312 
Day R. J. 1994. Algal symbiosis in Bunodeopsis: sea anemones with auxillary structures. Biological Bulletin 186: 182 - 194

D’Elia C. F., Domotor S. L. and Webb K. L. 1983. Nutrient uptake kinetics of freshly isolated zooxanthellae. Marine Biology 75: 157 - 167

Descolas-Gros C. and de Billy G. (1987). Temperatura adaptation of Rubí carboxylase: kinetic properties in marine Antarctic diatoms. Journal of Experimental Marine Biology and Ecology 108: 147 - 158

Douglas, A. E. (1994) Symbiotic Interactions. Oxford University Press, Oxford: 1160

Drew E. A. (1972). The biology and physiology of alga-invertebrate symbioses. II. The density of symbiotic algal cells in a number of hermatypic hard corals and alcyonarians from various depths. Journal of Experimental Marine Biology and Ecology 9: 71 - 75

Dubinsky Z., Falkowski P. G. and Wyman K. (1986). Light harvesting and utilization by phytoplankton. Plant and Cell Physiology 27: 1335 - 1349

Dubinsky Z. and Jokiel P. L. 1994. Ratio of energy and nutrient fluxes regulates symbiosis between zooxanthellae and corals. Pacific Science 48: 313 - 324 
Dunn S. R., Thomason J. C., Le Tissier M. D. A. and Bythell J. C. (2004). Heat stress induces different forms of cell death in sea anemones and their endosymbiotic algae depending on temperature duration. Cell and Differentiation 11: 1213 1222

Eckert R., Randall D. and Augustine G. (1988). Animal Physiology, Mechanisms and Adaptations. Freeman, New York

Edmunds P. J. and Davies P. S. (1989). An energy budget for Porites porites (Scleractinia), growing in a stressed environment. Coral Reefs 8: 37 - 43

Engebretson H. P and Muller-Parker G. (1999). Translocation of photosynthetic carbon from two algal symbionts to the sea anemone Anthopleura elegantissima. Biological Bulletin 197: $72-81$

Fadlallah Y. H. (1983) Sexual reproduction, development and larval biology in scleractinian corals. Coral Reefs 2: 129 - 150

Fagoonee I., Wilson H. B., Hassell M. P. and Turner J. R. (1999). The dynamics of zooxanthellae populations: A long-term study in the field. Science 283: 843 845

Falkowski P. G. and Owens T. G. (1980). Light - shade adaptation: Two strategies in marine phytoplankton. Plant Physiology 66: 592 - 595 
Falkowski P. G. and Dubinsky Z. (1981). Light-shade adaptation of Stylophora pistillata, a hermatypic coral from the Gulf of Eilat. Nature 289: 172 - 174

Falkowski P. G., Dubinsky Z., Muscatine L. and Porter J. W. (1984). Light and the bioenergetics of a symbiotic coral. Bioscience 34: 705 - 709

Falkowski P. G., Dubinsky Z. and Wyman K. (1985). Growth-irradiance relationships in phytoplankton. Limnology and Oceanography 30: 311 - 321

Farrant P. A., Borowitzka M. A., Hinde R. and King R. J. (1987a) Nutrition of the temperate Australian soft coral Capnella gaboenis. I. photosynthesis and carbon fixation. Marine Biology 95: 565 - 574

Farrant P. A., Borowitzka M. A., Hinde R. and King R. J. (1987b) Nutrition of the temperate Australian soft coral Capnella gaboenis. I. photosynthesis and carbon fixation. Marine Biology 95: 575 - 581

Ferrier, M. D. (1991) Net uptake of dissolved free amino acids by four Scleractinian corals. Coral Reefs 10: $183-187$

Fisher C. R., Fitt W. K. and Trench R. K. (1985). Photosynthesis and respiration in Tridacna gigas as a function of irradiance and size. Biolofical Bulletin 169: 230 $-245$ 
Fitt W. K. and Pardy R. L. (1981). Effects of starvation, and light and dark on the energy metabolism of symbiotic and aposymbiotic sea anemones, Anthopleura elegantissima. Marine Biology 61: 199 - 205

Fitt W. K., Pardy R. and Littler M. M. (1982). Photosynthesis, respiration and contribution to community productivity of the symbiotic sea anemone Anthopleura elegantissima (Brandt, 1835). Journal of Experimental Marine Biology and Ecology 61: 213 - 232

Fitt W. K. (1984). The role of chemosensory behaviour of Symbiodinium microadriaticum, intermediate hosts, and host behaviour in the infection of coelenterates and molluscs with zooxanthellae. Marine Biology 81: 9 - 17

Fitt W. K., Spero H. J., Halas J., White M. W. and Porter J. W. (1993). Recovery of the coral Montastrea annularis in the Florida Keys after the 1987 Caribbean "bleaching event”. Coral Reefs 12: 57 - 64

Fitt W. K. and Warner M. E. (1995). Bleaching patterns of four species of Caribbean reef corals. Biological Bulletin 189: 298 - 307

Fitt W. K. (2000). Cellular growth of host and symbiont in a cnidarian-zooxanthellar symbiosis. Biological Bulletin 198: 110 - 120 
Fitt W. K., McFarland F. K., Warner M. E. and Chilcoat G. C. (2000). Seasonal patterns of tissue biomass and densities of symbiotic dinoflagellates in reef corals and relation to coral bleaching. Limnology and Oceanography 45: 677 685

Fitt W. and Cook C. B. (2001). The effects of feeding or addition of dissolved inorganic nutrients in maintaining the symbiosis between dinoflagellates and a tropical marine cnidarian. Marine Biology 139: 507-17

Fricke H. and Meischner D. (1985). Depth limits of Bermudan scleractinian corals: a submersible survey. Marine Biology 88: 175 - 187

Gates R. D., Baghdasarian G. and Muscatine L. (1992). Temperature stress causes host cell detachment in symbiotic cnidarians: Implications for coral bleaching. Biological Bulletin 182: 324 - 332

Gates R. D. and Edmunds P. J. (1999). The physiological mechanisms of acclimatization in tropical reef corals. American Zoology 39: 30 - 43

Geider R. J., Osbonie B. A. and Raven J. A. (1986). Growth, photosynthesis and maintenance metabolic cost in the diatom Phaeodactylum tricornutum at very low light levels. Journal of Phycology 22: 39 - 48

Glynn P. W. and D'Croz L. (1990). Experimental evidence for high temperature stress as the cause of El Nino-coincident coral mortality. Coral Reefs 8: 181 - 191 
Glynn P. W. (1993). Coral Reef Bleaching: ecological perspectives. Coral Reefs 12: $1-17$

Glynn P. W. (1996). Coral reef bleaching: facts, hypothesis and implications. Global Change Biology 2: $495-509$

Goreau T. J. and Hayes R. L. (1994). Coral bleaching and ocean "hot spots". Ambio 23: $176-180$

Grigg R. W. (1982). Darwin Point: A threshold for atoll formation. Coral Reefs 1: 29 $-34$

Griffin S. P., Bhagooli R. and Weil E. (2006). Evaluation of thermal acclimation capacity in corals with different thermal histories based on catalase concentrations and antioxidant potentials. Comparative Biochemistry and Physiology, Part A 144: 155 - 162

Guinotte J. M. and Fabry V. J. (2008). Ocean acidification and its potential effects on marine ecosystems. Annals of the New York Academy of Sciences 1134: 320 $-342$

Harland A. D. and Davies P. S. (1994). Time-course of photoadaptation in the symbiotic sea anemone Anemonia viridis. Marine Biology 119: 45 - 51 
Hinga K. R. (2002). Effects of pH on coastal marine phytoplankton. Marine Ecology Progress Series 238: 281 - 300

Hoegh-Guldberg O., Hinde R. and Muscatine L. (1986). Studies on a nudibranch that contains zooxanthellae II. Contribution of zooxanthellae to animal respiration (CZAR) in Pteraeolidia ianthina with high and low densities of zooxanthellae. Proceedings of the Royal Society of London. Series B, Biological Sciences 228: $511-521$

Hoegh-Guldberg O., McCloskey L. R. and Muscatine L. (1987). Expulsion of zooxanthellae by symbiotic cnidarians from the Red Sea. Coral Reefs 5: 201 204

Hoegh-Guldberg O. and Smith G. J. (1989a). The effect of sudden changes in temperature, light and salinity on the population density and export of zooxanthellae from the reef corals Stylophora pistillata Esper and Seriatopora hystrix Dana. Journal of Experimental Marine Biology and Ecology 129: 279 $-303$

Hoegh-Guldberg O. and Smith G. J. (1989b). Influence of the population density of zooxanthellae and supply of ammonium on the biomass and metabolic characteristics of the reef corals Seriatopora hystrix and Stylophora pistillata. Marine Ecology Progress Series 57: 173 - 186 
Hoegh-Guldberg O. (1999). Climate change coral bleaching and the future of the world's coral reefs. Marine and Freshwater Research 50: 839 - 866

Hoegh-Guldberg O. and Fine M. (2004). Low temperatures cause coral bleaching. Coral Reefs 23: 444

Hoegh-Guldberg O., Mumby P. J., Hooten A. J., Steneck R. S., Greenfield P., Gomez E., Harvell C. D., Sale P. F., Edwards A. J., Caldeira K., Knowlton N., Eakin C. M., Iglesias-Prieto R., Muthiga N., Bradbury R. H., Dubai A. and Hatziolos M. E. (2007). Coral reefs under rapid climate change and ocean acidification. Science 318: 1737 - 1742

Hofmann D. K. and Kremer B. P. (1981). Carbon metabolism and strobilation in Cassiopea andromeda (Cnidarina: Scyphozoa): Significance of endosymbiotic dinoflagellates. Marine Biology 65: 25 - 33

Howe S. A. and Marshall A. T. (2001). Thermal compensation of metabolism in the temperate coral Plesiastrea versipora (Lamarck, 1816). Journal of Experimental Marine Biology and Ecology 259: 231 - 248

Huner N.P.A., Oquist G., Hurry V. M., Krol M., Falk S. and Griffith M. (1993). Photosynthesis, photoinhibition and low temperature acclimation in cold tolerant plants. Photosynthesis Research 37: 19 - 39 
Iglesias-Prieto R., Matta J. L., Robins W. A. and Trench R. K. (1992). Photosynthetic response to elevated temperature in the symbiotic dinoflagellate Symbiodinium microadriaticum in culture. Proceedings of the National Academy of Sciences of the United States of America 89: 10302 - 10305

Iglesias-Prieto R. and Trench R. K. (1994). Acclimation and adaptation to irradiance in symbiotic dinoflagellates. I. Responses of the photosynthetic unit to changes in photon flux density. Marine Ecology Progress Series 113: 163 - 175

Jacques T. G., Marshall N. and Pilson M. E. Q. (1983). Experimental ecology of the temperate scleractinian coral Astrangia danae. II. Effect of temperature, light intensity and symbiosis with zooxanthellae on metabolic rate and calcification. Marine Biology 76: $135-148$

Jennison B. L. (1979). Gametogenesis and reproductive cycles in the sea anemone Anthopleura elegantissima (Brandt, 1835). Canadian Journal of Zoology 57: $403-411$

Jensen S. and Muller-Parker G. (1994). Nutrient fluxes in anemone-dominated tidepools. Pacific Science 48: 32 - 43

Jokiel P. L. and York R. H. (1982). Importance of ultraviolet radiation in photoinhibition of microalgal growth. Limnology and Oceanography 29: 192 199 
Jones R. J. and Yellowlees D. (1997). Regulation and control of intracellular algae (= zooxanthellae) in hard corals. Philosophical Transactions of the Royal Society of London B 352: 457 - 468

Jones R. J., Hoegh-Guldberg O., Larkum A. W. D. and Schreiber U. (1998). Temperature-induced bleaching of corals begins with impairment of the $\mathrm{CO}_{2}$ fixation mechanism in zooxanthellae. Plant, Cell and Environment 21: 1219 1230

Kalituho L., Rech J. and Jahns P. (2007). The roles of specific xanthophylss in light utilisation. Planta 225: 423 - 439

Kevin K. M. and Hudson R. C. L. (1979). The role of zooxanthellae in the hermatypic coral Plesiastrea urvillei (Milne Edwards and Haime) from cold waters. Journal of Experimental Marine Biology and Ecology 36: 157 - 170

Kinzie R. A. (1974). Experimental infection of aposymbiotic gorgonian polyps with zooxanthellae. Journal of Experimental Marine Biology and Ecology 15: 335 $-345$

Kinzie III R. A. and Chee G. S. (1979). The effect of different zooxanthellae on the growth of experimentally reinfected hosts. Biological Bulletin 156: 315 - 327 
Kinzie III R. A. (1993). Effects of ambient levels of solar ultraviolet radiation on zooxanthellae and photosynthesis of the reef coral Montipora verrucosa. Marine Biology 116: 319 - 327

Kleypas J. A., McManus J. W. and Menez L. A. B. (1999). Environmental limits to coral reef development: Where do we draw the line? American Zoology 39: $146-159$

Kuster A., Schaible R. and Schubert H. (2000). Light acclimation of the charophyte Lamprothamnium papulosum. Aquatic Botany 68: 205 - 216

LaJeunesse T. C. and Trench R. K. (2000). Biogeography of two species of Symbiodinium (Freudenthal) inhabiting the intertidal sea anemone Anthopleura elegantissima (Brandt). Biological Bulletin 199: 126 - 134

LaJeunesse T. C. (2001). Investigating the biodiversity, ecology and phylogeny of endosymbiotic dinoflagellates in the genus Symbiodinium using the ITS region: in search of a "species" level marker. Journal of Phycology 37: 866 - 880

LaJeunesse T. C. (2002). Diversity and community structure of symbiotic dinoflagellates from Caribbean coral reefs. Marine Biology 141: 387 - 400 
LaJeunesse T. C. (2003). Low symbiont diversity in southern Great Barrier Reef corals, relative to those of the Caribbean. Limnology and Oceanography 48: $2046-2054$

LaJeunesse T. C. (2005). "Species" radiations of symbiotic dinoflagellates in the Atlantic and Indo-Pacific since the Miocene-Pliocene transition. Molecular Biology and Evolution 22: 570 - 581

Larcombe P., Ridd P.V., Prytz A. and Wilson B. (1995). Factors controlling suspended sediment on inner-shelf coral reefs, Townsville, Australia. Coral Reefs 14: 163 - 171

Leletkin V. A., Zvalinsky V. I. and Titlyanov E. A. 1980. Photosynthesis of zooxanthellae of corals from different depths. Plant Physiology 27: 1163 1170

Leletkin V. A. (2000). The energy budget of coral polyps. The Russian Journal of Marine Biology 26: 389 - 398

Lesser M. P. and Shick J. M. (1989). Effects of irradiance and ultraviolet radiation on photoadaptation in the zooxanthellae of Aiptasia pallida: primary production, photoinhibition, and enzymic defences against oxygen toxicity. Marine Biology 102: $243-255$ 
Lesser M. P., Stochaj W. R., Tapley D. W. and Shick J. M. (1990). Bleaching in coral reef anthozoans: effects of irradiance, ultraviolet radiation, and temperature on the activities of protective enzymes against active oxygen. Coral Reefs 8: 225 232

Lesser M. P. (1996). Elevated temperatures and ultraviolet radiation cause oxidative stress and inhabit photosynthesis in symbiotic dinoflagellates. Limnology and Oceanography 41: $271-283$

Lewis J. B. and Price W. S. 1975. Feeding mechanisms and feeding strategies of Atlantic reef corals. Journal of Zoology London 176: 527 - 544

Lin K., Wang J. and Fang. L. (2000). Participation of glycoproteins on zooxanthellal cell walls in the establishment of a symbiotic relationship with the sea anemone Aiptasia pulchella. Zoological Studies 39: 172 - 178

Lobban C. S., Schefter M., Simpson A. G. B., Pochon X., Pawlowski J. and Foissner W. (2002). Maristentor dinoferus n. gen., n. sp., a giant heterotrich ciliate (Spirotrichea: Heterotrichida) with zooxanthellae, from coral reefs on Guam. Mariana Islands. Marine Biology 140: 411 - 423

McAuley P. J. and Cook C. B. (1994). Effects of host feeding and dissolved ammonium on cell division and nitrogen status of zooxanthellae in the hydroid Myrionema amboinense. Marine Biology 121: 343 - 348 
McCloskey L. R., Muscatine L. and Wilkerson F. P. (1994). Daily photosynthesis, respiration, and carbon budgets in a tropical marine jellyfish (Mastigias sp.). Marine Biology 119: $13-22$

McCloskey L. R., Cove T. G. and Verde E. A. (1996). Symbiont expulsion from the anemone Anthopleura elegantissima (Cnidaria; Anthozoa). Journal of Experimental Marine Biology and Ecology 195: 173 - 186

McNaughtan D. (2008) The distribution and influence of the introduced algal Colpomenia bullosa in rocky intertidal. Msc Thesis, Victoria University

Marubini, F. and Davies, P. S. (1996) Nitrate increases zooxanthellae population density and reduces skeletogenesis in corals. Marine Biology 127: 319-328

Meints R. and Pardy R. (1980). Quantitative demonstration of cell surface involvement in a plant-animal symbiosis: lectin inhibition of reassociation. Journal of Cell Science 43: 239 - 251

Miller D. J. and Yellowlees D. (1989). Inorganic nitrogen uptake by symbiotic marine cnidarians: A critical review. Proceedings of the Royal Society of London. Series B, Biological Sciences 237: 109 - 125 
Miller D., Brown B. E., Sharp V. A. and Nganro N. (1992). Changes in the expression of soluble proteins extracted from the symbiotic anemone Anemonia viridis accompany bleaching induced by hyperthermia and metal stressors. Journal of Thermal Biology 17: 217 - 223

Moran, N. A. (2006) Symbiosis. Current Biology 16: 866-871

Morel A. and Ahn Y. H. (1990). Optical efficiency factors of free living marine bacteria: influence of bacterioplankton upon the optical properties and particulate organic carbon in oceanic waters. Journal of Marine Research 48: $145-175$

Morton and Miller (1968) The New Zealand Sea Shore. Tinling and Co Ltd. 638 pp

Morton J. (2004). Seashore Ecology of New Zealand and the Pacific. David Bateman Ltd. 504 pp

Mouritsen K. N. and Poulin R. (2003). The mud flat anemone-cockle association: mutualism in the intertidal zone? Oecologia 135: 131 - 137

Muller-Parker G. (1985). Effect of feeding regime and irradiance on the photophysiology of the symbiotic sea anemone Aiptasia pulchella. Marine Biology 90: 65 - 74 
Muller-Parker G. (1987). Seasonal variation in light-shade adaptation of natural populations of the symbiotic sea anemone Aiptasia pulchella (Carlgren, 1943) in Hawaii. Journal of Experimental Marine Biology and Ecology 112: 165 183.

Muller-Parker G., Lee K. W. and Cook C. B. (1996). Changes in the ultrastructure of symbiotic zooxanthellae (Symbiodinium sp. Dinophyceae) in fed and starved sea anemones maintained under high and low light. Journal of Phycology 32: 987 994

Muller-Parker G. and Davy S. K. (2001). Temperate and tropical algal-sea anemone symbioses. Invertebrate Biology 120: 104 - 123

Muscatine L. (1967) Glycerol extraction by symbiotic algae from corals and Tridacna and its control by the host. Science 156: 516-519

Muscatine L., Pool R. R. and Cernichiari E. (1972). Some factors influencing selective release of soluble organic material by zooxanthellae from reef corals. Marine Biology 13: $298-308$

Muscatine, L. and Porter, J. W. (1977). Reef corals: mutualistic symbioses adapted to nutrient-poor environments. Bioscience 27: 454-460 
Muscatine L. (1980). Productivity of zooxanthellae. Pp 381 - 402 in: Primary Productivity in the Sea. Falkowski P. G. (Ed.). Plenum Press. New York and London

Muscatine L., McCloskey L. R. and Marian R. E. (1981). Estimating the daily contribution of carbon from zooxanthellae to coral animal respiration. Limnology and Oceanography 26: $601-611$

Muscatine L., Falkowski P. G. and Dubinsky Z. (1983). Carbon budgets in symbiotic associations. Pp 649 - 658 in: Endocytobiology II Intracellular Space as Oligogenetic Ecosystem. Schenk H. E. A. and Schwemmler W. (Eds.). Walter de Gruyter, Berlin and New York

Muscatine L., Falkowski P.G., Porter J.W. and Dubinsky Z. (1984). Fate of photosynthetic fixed carbon in light and shade adapted colonies of the symbiotic coral Stylophora pistillata. Proceedings of the Royal Society of London. Series B, Biological Sciences 222: $181-202$

Muscatine L. Wilkerson E. P., McCloskey L. R. 1986. Regulation of population density of symbiotic algae in a tropical marine jellyfish (Mastigias sp.). Marine Ecology Progress Series 32: 279 - 290

Muscatine L., Grossman D., and Doino J. (1991). Release of symbiotic algae by tropical sea anemones and corals after cold shock. Marine Ecology Progress Series $77: 233-243$ 
Muscatine L., Gates R. D. and La Fontaine I. (1994). Do symbiotic dinoflagellates secrete lipid droplets? Limnology and Oceanography 39: 925 - 929

Muthiga N. A. and Szmant A. M. (1987) The effects of salinity stress on the rates of aerobic respiration and photosynthesis in the hermatypic coral Siderastrea sidereal. Biological Bulletin 173: 539 - 551

Nakamura E., Yokohama Y. and Tanaka J. (2003). Photosynthetic activity of a temperate coral Acropora pruinosa (Scleractinia, Anthozoa) with symbiotic algae in Japan. Phycological Research 51: 38 - 44

Navarro E., Ortega M. M. and Madariaga J. M. (1981). Effect of body size, temperature and shore level on aquatic and aerial respiration of Actinia equina (Anthozoa). Journal of Experimental Marine Biology and Ecology 53: 153 162

Nii C. M. and Muscatine L. (1997). Oxidative stress in the symbiotic sea anemone Aiptasia pulchella (Carlgren, 1943): Contribution of the animal to superoxide ion production at elevated temperature. Biological Bulletin 192: 444 - 456

O'Brien T. L. and Wyttenbach C. R. (1980). Some effects of temperature on the symbiotic association between zoochlorellae (Chlorophyceae) and the sea anemone Anthopleura xanthogrammica. Transactions of the American Microscopical Society 99: 221 - 225 
Oquist G. (1983). Effects of low temperature on photosynthesis. Plant, Cell and Environment 6: 281 - 300

Perry M. J., Talbot M. C. and Alberte R. S. (1981). Photoadaptation in marine phytoplankton: Response of the photosynthetic unit. Marine Biology 62: 91 101

Phillips S. (2006). Latitudinal diversity of the symbiotic dinoflagellate Symbiodinium in New Zealand. Msc Thesis, Victoria University

Pochon X., Pawlowski J., Zaninetti L., and Rowan R. (2001). High genetic diversity and relative specificity among Symbiodinium-like endosymbiotic dinoflagellates in soritid foraminiferans. Marine Biology 139: 1069 - 1078

Pochon X., LaJeunesse T. C., and Pawlowski J. (2004). Biogeographic portioning and host specialization among foraminiferan dinoflagellate symbionts (Symbiodinium, Dinophyta). Marine Biology 146: 17 - 27

Porter J.W. Muscatine L., Dubinsky Z. and Falkowski P. G. (1984). Primary production and photoadaptation in light and shade adapted colonies of the symbiotic coral Stylophora pistillata. Proceedings of the Royal Society of London. Series B, Biological Sciences 222: 161 - 180 
Post A. F., Dubinsky Z., Wyman K. and Falkowski P. G. (1984). Kinetics of light intensity adaptation in a marine planktonic diatom. Marine Biology 83: 231 238

Rands M. L., Loughman B. C. and Douglas A. E. (1993) The symbiotic interface in an alga-invertebrate symbiosis. Proceedings of the Royal Society of London. Series B, Biological Sciences 253: 161 - 165

Raven J. A. and Geider R. J. (1988). Temperature and algal growth. New Phytologist 110: $441-461$

Rees T. A. V. (1986). The green hydra symbiosis and ammonium I. The role of the host in ammonium assimilation and its possible regulatory significance. Proceedings of the Royal Society of London. Series B, Biological Sciences 229: $299-314$

Rees T. A. V. and Ellard F. M. (1989). Nitrogen conservation and the green hydra symbiosis. Proceedings of the Royal Society of London. Series B, Biological Sciences 236: $203-212$

Richmond R. H. and Hunter C. L. (1990). Reproduction and recruitment of corals: comparisons among the Caribbean, the tropical pacific, and the Red Sea. Marine Ecology Progress Series 60: 185 - 203 
Rodriguez-Lanetty M., Chang S. J. and Song J. (2003). Specificity of two temperate dinoflagellate-anthozoan associations from the north western Pacific Ocean. Marine Biology 143: 1193 - 1199

Rowan R. and Powers D. A. (1991). Molecular genetic identification of symbiotic dinoflagellates (zooxanthellae). Marine Ecology Progress Series 71: 65 - 73

Rowan R. and Powers D. A. (1992). Ribosomal RNA sequences and the diversity of symbiotic dinoflagellates (zooxanthellae). Proceedings of the National Academy of Sciences of the United States of America 89: 3639 - 3643

Rowan R. (1998). Diversity and ecology of zooxanthellae on coral reefs. Journal of Phycology 34: 407 - 417

Rowan R. (2004). Thermal adaptation in reef coral symbionts. Nature 430: 7001

Sachs J. L. and Wilcox T. P. (2006). A shift to parasitism in the jellyfish symbiont Symbiodinium microadriaticum. Proceedings of the Royal Society B 273: 425 429

Santos S. R., Taylor D. J. and Coffroth M. A. (2001). Genetic comparisons of freshly isolated versus cultured symbiotic dinoflagellates: implications for extrapolating to the intact symbiosis. Journal of Phycology 37: 900 - 912 
Santos S. R., Taylor D. J., Kinzie R. A., Hidaka M., Sakai. and Coffroth M. A. (2002). Molecular phylogeny of symbiotic dinoflagellates inferred from partial chloroplast large subunit (23S)-rDNA sequences. Molecular Phylogenetics Evolution 23: 97 - 111

Saunders B. K. and Muller-Parker G. (1997). The effects of temperature and light on two algal populations in the temperate sea anemone Anthopluera elegantissima (Brandt, 1835). Journal of Experimental Marine Biology and Ecology 211: $213-224$

Saxby T., Dennison W. C. and Hoegh-Guldberg O. (2003). Photosynthetic responses of the coral Montipora digitata to cold temperature stress. Marine Ecology Progress Series 248: 85 - 97

Schmitz K. and Kremner B. P. 1977. Carbon fixation and analysis of assimilates in a coral-dinoflagellate symbiosis. Marine Biology 42: 305 - 313

Schiller C. (1993). Ecology of the symbiotic coral Cladocera caespitose (L.) (Faviidae, Scleractinia) in the Bay of Piran (Adriatic sea): ii. Energy budget. P.S.Z.N.I. Marine Ecology 14: 221 - 238 
Schoenberg, D. A. and Trench, R. K. (1980) Genetic variation in Symbiodinium (=Gymnodinium) microadriaticum Freudenthal, and specificity in its symbionts with marine invertebrates. III. Specificity and infectivity of S. microadriaticum. Proceedings of the Royal Society of London. Series B, Biological Sciences 207: $445-460$

Schwarz J. A., Krupp D. A. and Weis V. M. (1999). Late larval development and onset of symbiosis in the scleractinian coral Fungia scutaria. Biological Bulletin 196: 70 - 79

Schwarz J. A., Weis V. M. and Potts, D. C. (2002) Feeding behaviour and acquisition of zooxanthellae by the planulae larvae of the sea anemone Anthopleura elegantissima. Marine Biology 140: 471-478

Searle J., Kerr J. F. R. and Bishop C. J. (1982). Necrosis and apoptosis: distinct modes of cell death who fundamentally different significance. Pathology Annual 17: 229 - 259

Shakir F. K., Audilet D., Drake III A. J. and Mohamed Shakir K. M. (1994). A rapid protein determination by modification of the Lowry procedure. Analytical Biochemistry 216: $232-233$

Shick J. M. and Dykens J. A. (1984). Photobiology of the symbiotic sea anemone Anthopleura elegantissima: Photosynthesis, respiration, and behaviour under intertidal conditions. Biological Bulletin 166: 608 - 619 
Shick J. M., Lesser M. P. and Stochaj W. R. (1991). UV radiation and photooxidative stress in zooxanthellate anthozoa: the sea anemone Phyllodiscus semoni and the octocoral Clavularia sp. Symbiosis 10: 145 - 173

Shick J. M., Lesser M. P., Dunlap W. C., Stochaj W. R., Chalker B. E. and Wu Won J. (1995). Depth-dependent responses to solar ultraviolet radiation and oxidative stress in the zooxanthellate coral Acropora microphthalma. Marine Biology 122: $41-51$

Shick J. M., Lesser M. P. and Jokiel P. L. (1996). Ultraviolet radiation and coral stress. Global Change Biology 2: 527 - 545

Smith D. C. (1974). Transport from symbiotic algae and symbiotic chloroplasts to host cells. Symposia of the Society for Experimental Biology 19: 485 - 520

Smith D. C and Douglas A. E. (1987). The Biology of Symbiosis. Edward Arnold, London: 1 - 315

Smith G. J. and Muscatine L. (1986). Carbon budgets and regulation of the population density of symbiotic algae. Endocytobiosis and Cell Research 3: 213 - 238

Smith G. J. and Muscatine L. (1999). Cell cycle of symbiotic dinoflagellates: variation in $\mathrm{G}_{1}$ phase-duration with anemone nutritional status and 
macronutrient supply in the Aiptasia pulchella - Symbiodinium pulchrorum symbiosis. Marine Biology 134: 405 - 418

Smith D. J., Suggett D. J. and Baker N. R. (2005). Is photoinhibition of zooxanthellae photosynthesis the primary cause of thermal bleaching in corals? Global Change Biology 11: 1 - 11

Stambler N. and Dubinsky Z. (1987). Energy relationships between Anemonia sulcata and its endosymbiotic zooxanthellae. Symbiosis 3: 233 - 248

Stat M., Carter D. and Hoegh-Guldberg O. (2006). The evolutionary history of Symbiodinium and scleractinian hosts - Symbiosis, diversity, and the effect of climate change. Perspectives in Plant Ecology, Evolution and Systematics 8: $23-43$

Stat M., Morris E. and Gates R. D. (2008) Functional diversity in coral-dinoflagellate symbiosis. Proceedings of the National Academy of Sciences 105: 9256 9261

Steen R. G. and Muscatine L. (1984). Daily budgets of photosynthetically fixed carbon in symbiotic zoanthids. Biological Bulletin 167: 477 - 487

Steen R. G. and Muscatine L. (1987). Low temperature evokes rapid exocytosis of symbiotic algae by a sea anemone. Biological Bulletin 172: 246 - 263 
Stimson J. (1997). The annual cycle of density of zooxanthellae in the tissues of field and laboratory-held Pocillopora damicornis (Linnaeus). Journal of Experimental Marine Biology and Ecology 214: 35 - 48

Strathmann R. R. (1967). Estimating the organic carbon content of phytoplankton from cell volume or plasma volume. Limnology and Oceanography 12: 411 418

Streamer M., McNeil Y. R. and Yellowless D. (1993) Photosynthetic carbon dioxide fixation in zooxanthellae. Marine Biology 115: 195 - 198

Strychar K. B., Coates M., Sammarco P.W., Piva T. J. and Scott P. T. (2005). Loss of Symbiodinium from bleached soft corals Sarcophyton ehrenbergi, Sinularia sp. and Xenia sp. Journal of Experimental Marine Biology and Ecology 320: 159 $-177$

Suharsono and Brown B. E. (1992). Comparative measurements of mitotic index in zooxanthellae from a symbiotic cnidarian subject to temperature increase. Journal of Experimental Marine Biology and Ecology 158: 179 - 188

Sutton D. C. and Hoegh-Guldberg O. (1990). Host-zooxanthellae interactions in four temperate marine invertebrate symbioses: Assessment of effect of host extracts on symbionts. Biological Bulletin 178: 175 - 186 
Szmant-Froelich A. and Pilson M. E. Q. 1984. Effects of feeding frequency and symbiosis with zooxanthellae on nitrogen metabolism and respiration of the coral Astrangia danae. Marine Biology 81: 153 - 162

Takabayashi M., Santos S. R. and Cook C. B. (2004). Mitochondrial DNA phylogeny of the symbiotic dinoflagellates (Symbiodinium, Dinophyta). Journal of Phycology 40: 160 - 164

Takashita K., Ishikura M., Koike K. and Maruyama T. (2003). Comparison of phylogenies based on nuclear-encoded SSU rDNA and plastid-encoded $p s b A$ in the symbiotic dinoflagellate genus Symbiodinium. Phycologia 42: 285 - 291

Tchernov D., Gorbunov M. Y., de Vargas C., Yadav S. N., Milligan A. J., Haggblom M. and Falkowski P. G. (2004). Membrane lipids of symbiotic algae are diagnostic of sensitivity to thermal bleaching in corals. Proceedings of the national Academy of Sciences 101: 13531 - 13535

Titlyanov E. A. Shaposhnikova M. G. and Zvalinsky V. I. 1980. Photosynthesis and adaptation of corals to irradiance: 1 . Contents and native state of photosynthetic pigments in symbiotic microalgae. Photosynthetica 14: 413 - 421

Titlyanov E., Bil K., Fomina I., Titlyanova T., Leletkin V., Eden N., Malkin A. and Dubinsky Z. (2000). Effects of dissolved ammonium addition and host feeding with Artemia salina on photo-acclimation of the hermatypic coral Stylophora pistillata. Marine Biology 137: 463 - 472 
Titlyanov E. A., Titlyanova T. V., Yamazato K. and van Woesik R. (2001). Photoacclimation dynamics of the coral Stylophora pistillata to low and extremely low light. Journal of Experimental Marine Biology and Ecology 263: 211 225

Titlyanov E. A. and Titlyanova T. V. (2002). Reef-building corals-symbiotic autotrophic organisms: 2. Pathways and mechanisms of adaptation to light. Russian Journal of Marine Biology 28: 16 - 31

Toller W. W., Rowan R. and Knowlton N. (2001). Zooxanthellae of the Montastraea annularis species complex: patterns of distribution of four taxa of Symbiodinium on different reefs and across depths. Biological Bulletin 201: 348 - 359

Trench R. K. (1971). The physiology and biochemistry of zooxanthellae symbiotic with marine coelenterates. III. The effect of homogenates of host tissues on the excretion of photosynthetic products in vitro by zooxanthellae from two marine coelenterates. Proceedings of the Royal Society of London 177: 251 - 264

Trench R. K. (1979). The cell biology of plant-animal symbiosis. Annual Review of Plant Physiology 30: 485 - 531

Trench R. K. and Fisher C. R. (1983). Carbon dioxide fixation in Symbiodinium microadriaticum: Problems with mechanisms and pathways. Endocytobiology 11: $659-673$ 
Trench R. K. (1987). Dinoflagellates in Non-Parasitic Symbioses. in The Biology of Dinoflagellates. Taylor F. J. R. (Ed.) Blackwell, Oxford: 530 - 570

Tytler E. M. and Trench R. K. (1986). Activities of enzymes in B-carboxylation reactions and catalase in cell-free preparations from the symbiotic dinoflagellates Symbiodinium spp. from a coral, a clam a zoanthid and two sea anemones. Proceedings of the Royal Society of London 228: 483 - 492

Venn A. A., Loram J. E. and Douglas A. E. (2008). Photosynthetic symbioses in animals. Journal of Experimental Botany: 1 - 12

Verde E. A. and McCloskey L. R. (1996a). Carbon budget studies of symbiotic cnidarian anemones - Evidence in support of some assumptions. Journal of Experimental Marine Biology and Ecology 195: 161 - 171

Verde E. A. and McCloskey L. R. (1996b). Photosynthesis and respiration of two species of algal symbionts in the anemone Anthopleura elegantissima (Cnidaria; Anthozoa). Journal of Experimental Marine Biology and Ecology 195: 187 202

Verde E. A. and McCloskey L. R. (1998). Production, respiration, photophysiology of the mangrove jellyfish Cassiopea xamachana symbiotic with zooxanthellae: effect of jellyfish size and season. Marine Ecology Progress Series 168: 147 162 
Verde E. A. and McCloskey L. R. (2001). A comparative analysis of the photobiology of zooxanthellae and zoochlorellae symbiotic with the temperate clonal anemone Anthopleura elegantissima (Brandt). I. Effect of temperature. Marine Biology 138: 477 - 489

Verde E. A. and McCloskey L. R. (2002). A comparative analysis of the photobiology of zooxanthellae and zoochlorellae symbiotic with the temperate clonal anemone Anthopleura elegantissima. Marine Biology 141: 225 - 239

Verde E. A. and McCloskey L. R. (2007). A comparative analysis of the photobiology of zooxanthellae and zoochlorellae symbiotic with the temperate clonal anemone Anthopleura elegantissima (Brandt). III. Seasonal effects of natural light and temperature on photosynthesis and respiration. Marine Biology 152: $775-792$

Wang J. T. and Douglas A. E. (1998). Nitrogen recycling or nitrogen conservation in an alga-invertebrate symbiosis? The Journal of Experimental Biology 201: $2445-2453$

Warner M. E., Fitt W. K. and Schmidt G. W. (1996). The effects of elevated temperature on the photosynthetic efficiency of zooxanthellae in hospite from four different species of reef coral: a novel approach. Plant, Cell and Environment 19: $291-299$ 
Warner M. E., Fitt W. K. and Schmidt G. (1999). Damage to photosystem II in symbiotic dinoflagellates: A determinant of coral bleaching. Ecology 96: 8007 8012

Webber M. K. and Roff J. C. (1995). Annual structure of the copepod community and its associated pelagic environment off Discovery Bay, Jamaica. Marine Biology 123: 467 - 479

Weis V. M., Reynolds W. S., de Boer M. L. and Krupp D. A. (2001) Host-symbiont specificity during onset of symbiosis between the dinoflagellate Symbiodinium sp. and the Scleractinian coral Fungia scutaria. Coral Reefs 20: 301-308

Wilkerson, D. M. (2001). At cross purposes. How do we cope with scientific terms that have two different definitions? Nature 412: 485

Wilkerson F. P., Muller-Parker G. and Muscatine L. (1983). Temporal patterns of cell division in natural populations of endosymbiotic algae. Limnology and Oceanography 28: $1009-1014$

Wilkerson F. P. and Muscatine L. (1984) Uptake and assimilation of dissolved inorganic nitrogen by a symbiotic sea anemone. Proceedings of the Royal Society of London. Series B, Biological Sciences 221: 71-86

Wilkerson F. P., Kobayashi D. and Muscatine L. (1988). Mitotic Index and size of symbiotic algae in Caribbean reef corals. Coral Reefs 7: 29 - 36 
Wood-Charlson E. M., Hollingsworth L. L., Krupp D. A., and Weis V. A. (2006). Lectin/glycan interactions play a role in recognition in a coral/dinoflagellate symbiosis. Cellular Microbiology 8: 1985 - 1993 